Supplementary Information

\title{
Site-specific di-functionalization of structured RNAs yields probes for microRNA maturation
}

Ugo Pradère and Jonathan Hall*

Institute of Pharmaceutical Sciences, Department of Chemistry and Applied Biosciences, ETH Zurich, 8093 Zurich, Switzerland 


\section{Table of Content}

1. General experimental details

2. Oligonucleotide synthesis, incorporation of modified phosphoramidites and work-up of modified pre-miRNAs .4

3. Optimization of azidation reaction on pre-miR-21

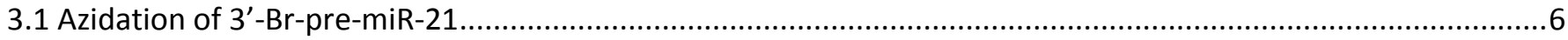

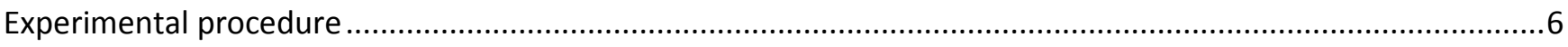

HPLC-profile of crude 3'-N

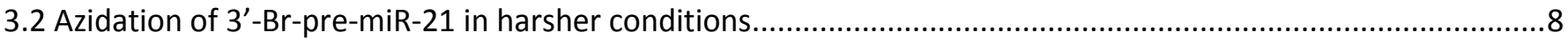

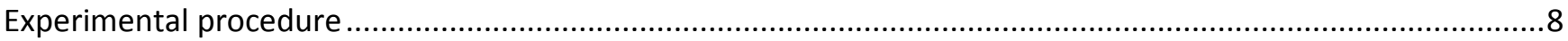

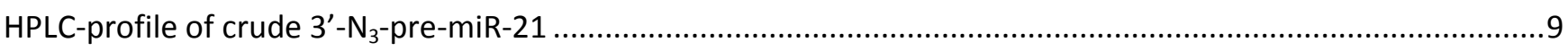

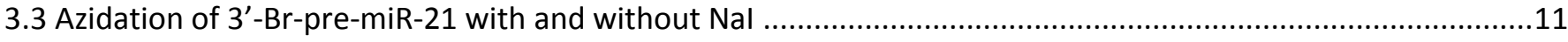

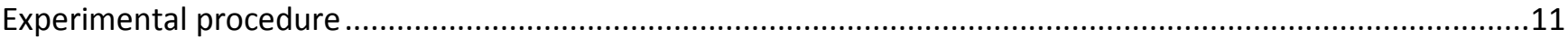

HPLC-profile of crude 3'-N

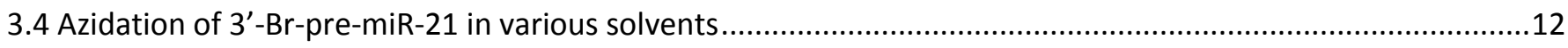

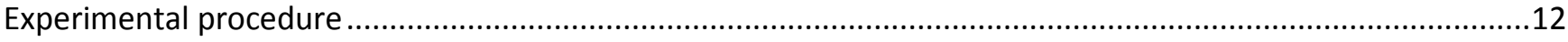

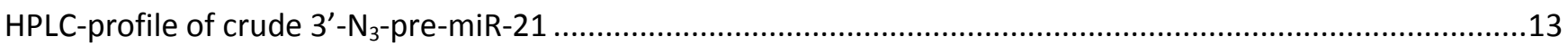

4. Optimization of reverse-click reaction in solution phase on pre-miR-21 ......................................................14

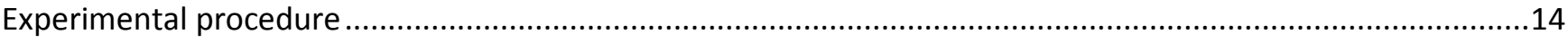

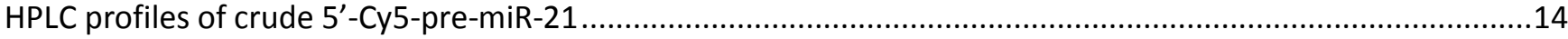

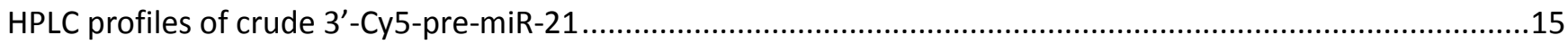

5. Evaluation of reverse-click reaction on solid support on pre-miR-21 in different conditions ...........................16

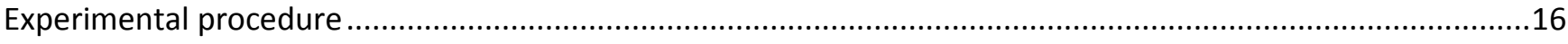

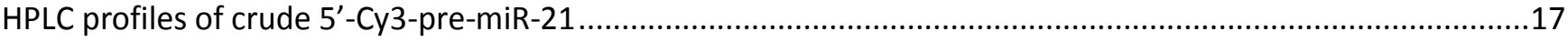

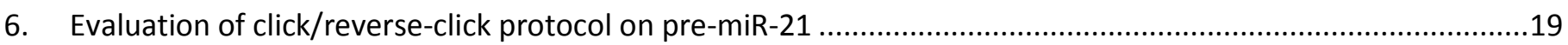

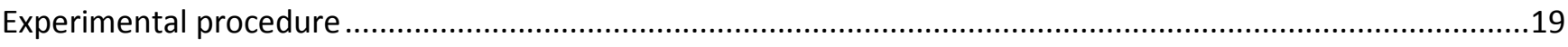

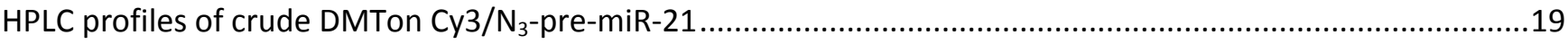

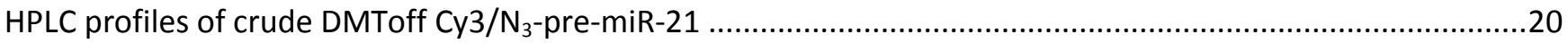

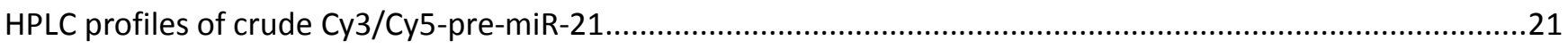

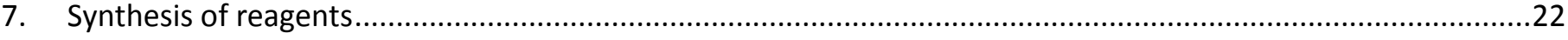

7.1 2'-O-methylenetriazolobutylbromide cytidine phosphoramidite ............................................................22

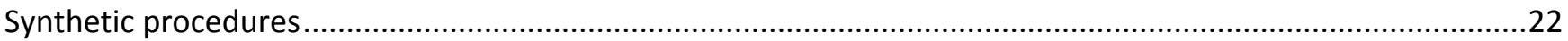

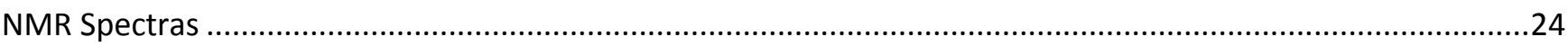

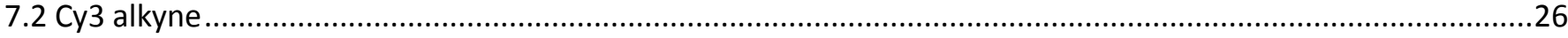




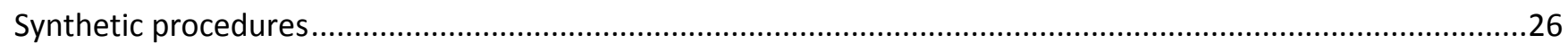

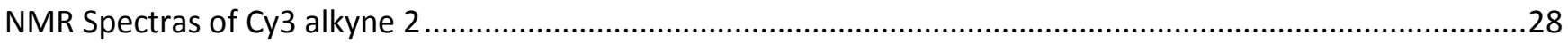

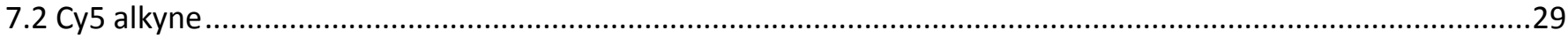

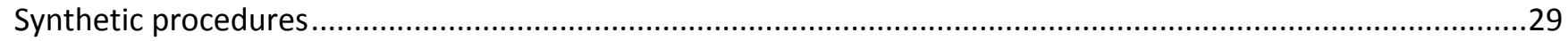

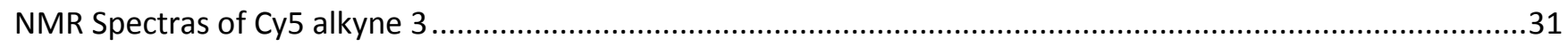

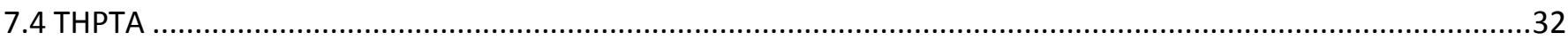

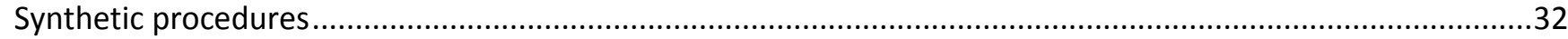

8. Sequences of ORN1 to ORN14

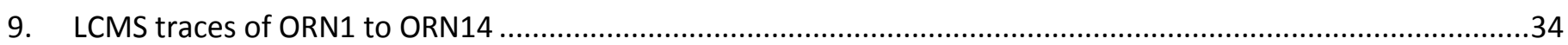

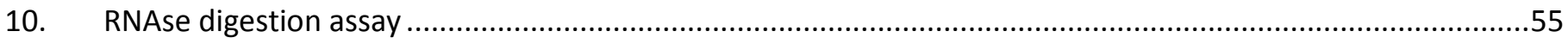

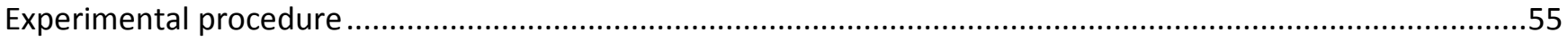

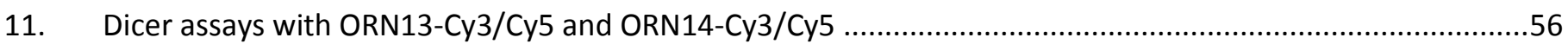

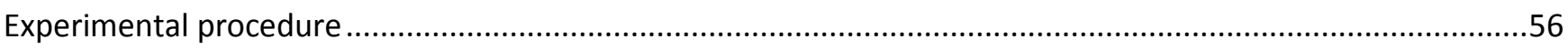

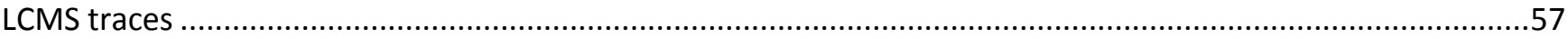

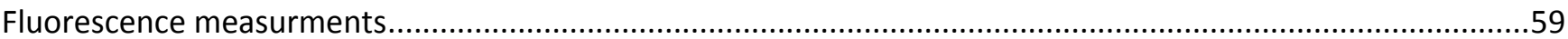




\section{General experimental details}

Chemicals were purchased from Aldrich and TCI. Phosphoramidites were purchased from Thermo Fisher. The activator 5-benzylthiotetrazole was purchased from Biosolve. All oligonucleotides used in this work were synthesized with a MM12 synthesizer from Bio Automation Inc. on $1000 \AA$ UnyLinker CPG from ChemGenes. The coupling time for phosphoramidites was 2 x $90 \mathrm{~s}$. The oligonucleotides were purified on an Agilent 1200 series preparative HPLC on a Waters XBridge OST C-18 column, $10 \times 50 \mathrm{~mm}, 2.5 \mu \mathrm{m}$ at $65{ }^{\circ} \mathrm{C}$. Buffer A: $0.1 \mathrm{M}$ aqueous triethylamine/acetic acid, pH 8.0; buffer B: $100 \% \mathrm{MeOH}$; flow-rate: $5 \mathrm{~mL} / \mathrm{min}$. Gradient for the DMT-on and DMToff purification: $5 \%$ to $100 \%$ buffer B over $10 \mathrm{~min}$. Fractions containing the product were collected and dried in a miVac duo SpeedVac from Genevac. The oligonucleotides were analyzed by LC-MS (Agilent 1200/6130 system) on a Waters Acquity OST C-18 column, 2.1 x $50 \mathrm{~mm}, 1.7 \mu \mathrm{M}, 65^{\circ} \mathrm{C}$. Buffer A: 0.4M HFIP, $15 \mathrm{mM}$ triethylamine; buffer B: MeOH. Gradient: 5-80\% B in $10 \mathrm{~min}$; flow-rate: $0.3 \mathrm{~mL} / \mathrm{min}$.

\section{Oligonucleotide synthesis, incorporation of modified phosphoramidites and work-up of modified pre-miRNAs}

10 solutions were prepared for these experiments directly prior use:

- $\quad$ Solution 1: PBS buffer/MeOH (1:1): $5 \mathrm{~mL}$ of PBS buffer, $5 \mathrm{~mL}$ of $\mathrm{MeOH}$.

- $\quad$ Solution 2: TBTA [50 mM] in DMF: $0.27 \mathrm{mg}$ of TBTA in $40 \mu \mathrm{L}$ of DMF.

- $\quad$ Solution 3: Cy3 azide [50 mM] in DMF: $0.56 \mathrm{mg}$ of Cy3 azide in $40 \mu \mathrm{L}$ of DMF.

- $\quad$ Solution 4: $\mathrm{CuSO}_{4} .5 \mathrm{H}_{2} \mathrm{O}[5 \mathrm{mM}]$ in $\mathrm{H}_{2} \mathrm{O}: 12.5 \mathrm{mg}$ of $\mathrm{CuSO}_{4} .5 \mathrm{H}_{2} \mathrm{O}$ in $10 \mathrm{~mL}$ of water.

- Solution 5: Na-ascorbate $[50 \mathrm{mM}]$ in $\mathrm{H}_{2} \mathrm{O}: 10 \mathrm{mg}$ of Na-ascorbate in $1 \mathrm{~mL}$ of water.

Solution 6: $\mathrm{NaN}_{3}$ [400 mM]: $0.65 \mathrm{mg}$ of $\mathrm{NaN}_{3}$ in $110 \mu \mathrm{L}$ of DMF.

Solution 7: THPTA [50mM]: $1.1 \mathrm{mg}$ of THPTA in $50 \mu \mathrm{L}$ of water.

Solution 8: Cy5 alkyne [20mM]: 1.18mg of Cy5 alkyne in $100 \mu \mathrm{L}$ of DMF.

Solution 9: $\mathrm{CuSO}_{4} \cdot 5 \mathrm{H}_{2} \mathrm{O}[20 \mathrm{mM}]: 5 \mathrm{mg}$ of $\mathrm{CuSO}_{4} \cdot 5 \mathrm{H}_{2} \mathrm{O}$ in $1 \mathrm{~mL}$ of water.

Solution 10: $\mathrm{Na}$ ascorbate [100mM]: 20mg of $\mathrm{Na}$ ascorbate in $1 \mathrm{~mL}$ of water.

Oligoribonucleotides were synthesized with regular 2'-O-TBDMS-phosphoramidites on a $50 \mathrm{nmol}$ scale using $5 \mathrm{mg}$

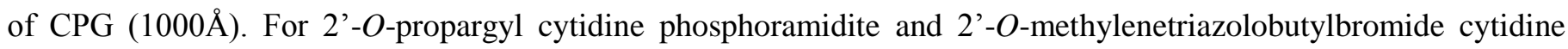
phosphoramidite, the coupling time was prolonged to 2 × 3 min. After synthesis, the CPG with the modified RNA was suspended in $300 \mu \mathrm{L}$ of PBS buffer/MeOH (1:1) (solution 1) in an Eppendorf tube. Subsequently, freshly-prepared solutions of TBTA (solution 2, $40 \mu \mathrm{L}$ ), azide (solution 3, $40 \mu \mathrm{L}$ ), $\mathrm{CuSO}_{4} .5 \mathrm{H}_{2} \mathrm{O}$ (solution $4,10 \mu \mathrm{L}$ ) and Na-ascorbate (solution 5, $10 \mu \mathrm{L}$ ) were added to the suspension. The reaction mixture was shaken for $16 \mathrm{~h}$ at $45{ }^{\circ} \mathrm{C}$ in an Eppendorf shaker. CPG was filtered, washed three times with $0.5 \mathrm{~mL}$ of DMF, $0.1 \mathrm{~N}$ aqueous EDTA, DMF, and acetonitrile. 
CPG was transferred into an Eppendorf tube and suspended in a DMF solution of sodium azide (solution 6, $110 \mu \mathrm{L}$ ). The reaction mixture was shaken vigorously for $6 \mathrm{~h}$ at $45^{\circ} \mathrm{C}$ in an Eppendorf shaker. The CPG was filtered and washed three times with successively $1 \mathrm{~mL}$ of DMF and acetonitrile. The CPG was transferred into an Eppendorf tube, dried under high vacuum for $2 \mathrm{~h}$ and treated with $200 \mu \mathrm{L}$ of ammonia $\left(25 \%\right.$ in $\left.\mathrm{H}_{2} \mathrm{O}\right)$ and $200 \mu \mathrm{L}$ of aqueous methylamine ( $40 \%$ in $\mathrm{H}_{2} \mathrm{O}$ ) solutions for $6 \mathrm{~h}$ at room temperature. After filtration, the remaining RNA was washed from the solid support with $3 \times 100 \mu \mathrm{L} \mathrm{H}_{2} \mathrm{O} / \mathrm{EtOH}(1: 1)$. To the solution was added $20 \mu \mathrm{L}$ of $1 N$ Tris-base and it was evaporated to dryness in a SpeedVac. Desilylation was carried out by treatment with $130 \mu \mathrm{L}$ of a mixture of NMP (60 $\mu \mathrm{L})$, TEA $(30 \mu \mathrm{L})$ and TEA. $3 \mathrm{HF}(40 \mu \mathrm{L})$ at $70{ }^{\circ} \mathrm{C}$ for $90 \mathrm{~min}$. The reaction was quenched with trimethylethoxysilane $(160 \mu \mathrm{L})$ for $20 \mathrm{~min}$ at room temperature on an Eppendorf shaker. Diethylether $(1 \mathrm{~mL})$ was added, the mixture was vortexed and centrifuged at $4{ }^{\circ} \mathrm{C}$ for $2 \mathrm{~min}$. The supernatant was taken off and the precipitate was washed twice with $1 \mathrm{~mL}$ diethylether, vortexed and centrifuged. The oligonucleotide was dissolved in $200 \mu \mathrm{L}$ of water and purified DMT-on by RP-HPLC. The isolated product was dried in a SpeedVac and treated for $1 \mathrm{~h}$ with $40 \%$ aq. acetic acid at room temperature. The Cy3/N 3 -DMToff pre-miRNA was dried in a SpeedVac and diluted in water.

To $2 \mathrm{nmol}$ of modified RNA in $20 \mu \mathrm{L}$ of water was successively added PBS buffer ( $\mathrm{pH}=7.4,28.5 \mu \mathrm{L})$, THPTA (solution 7, $2.5 \mu \mathrm{L}$ ), Cy5 alkyne (solution 8, $1.25 \mu \mathrm{L}$ ), $\mathrm{CuSO}_{4} .5 \mathrm{H}_{2} \mathrm{O}$ (solution 9, $1.25 \mu \mathrm{L}$ ) and $\mathrm{Na}$ ascorbate (solution $10,2.5 \mu \mathrm{L}$ ). After incubation of the reaction mixture for $2 \mathrm{~h}$ at $65{ }^{\circ} \mathrm{C}$, the solution was cooled down to room temperature. Water $(150 \mu \mathrm{L})$ was successively added and the solution extracted three times with $200 \mu \mathrm{L}$ of EtOAc. $\mathrm{NaOAC}(25 \mu \mathrm{L}$ of a $3 \mathrm{M}$ solution) and $800 \mu \mathrm{L}$ of EtOH:iPrOH (2:1) were added and RNA was precipitated for 30min at $-80^{\circ} \mathrm{C}$ (alternatively, $-20^{\circ} \mathrm{C}$ can be used for $12 \mathrm{~h}$ ). After centrifugation (20min, 14000rpm), supernatant was removed, the RNA pellets dissolved in water $(200 \mu \mathrm{L})$ and purified by RP-HPLC to yield pure Cy3/Cy5 bis-labeled RNA. 


\section{Optimization of azidation reaction on pre-miR-21}

\subsection{Azidation of 3'-Br-pre-miR-21}

\section{Experimental procedure}

Two solutions were prepared for these experiments directly prior use:

- Solution 1: $1.3 \mathrm{mg}$ of $\mathrm{NaN}_{3}$ in $600 \mu \mathrm{L}$ of DMF.

- $\quad$ Solution 2: $3 \mathrm{mg}$ of $\mathrm{NaI}$ in $200 \mu \mathrm{L}$ of DMF.

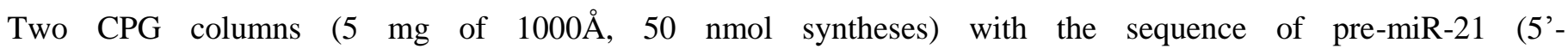
CAGCUUAUCAGACUGAUGUUGACUGUUGAAUCUCAUGGCAACACCAGUCGAUGGGCUGUC $\left.\mathrm{Br}_{\mathrm{Br}}\right)\left(\mathrm{C}_{\mathrm{Br}}: 2\right.$ '$O$-methylenetriazolo-bromobutane) were prepared. CPGs were combined and mixed in an Eppendorf tube before being equally redistributed into 4 Eppendorf tubes. Sodium azide $\left(150 \mu \mathrm{L}\right.$ of solution 1 , final $\left.\left[\mathrm{NaN}_{3}\right]=25 \mathrm{mM}\right)$ and sodium iodide $(50 \mu \mathrm{L}$ of solution 2 , final $[\mathrm{NaI}]=25 \mathrm{mM})$ were added. The reaction mixture was shaken vigorously for the corresponding time (respectively $1 \mathrm{~h}, 2 \mathrm{~h}, 4 \mathrm{~h}, 8 \mathrm{~h}$ ) on an Eppendorf shaker. The CPGs were filtered and washed successively with $1 \mathrm{~mL}$ of DMF and acetonitrile. After cleavage from the solid support and RNA deprotection (aq. $\left.\mathrm{MeNH}_{2} / \mathrm{NH}_{4} \mathrm{OH}, \mathrm{TEA} . \mathrm{HF}\right)$, the composition of the crude solution was evaluated by integration of peaks in the HPLC chromatograms (see following spectra). 
HPLC-profile of crude 3 '- $\mathrm{N}_{3}$-pre-miR-21

$1 \mathrm{~h}, 45^{\circ} \mathrm{C}$
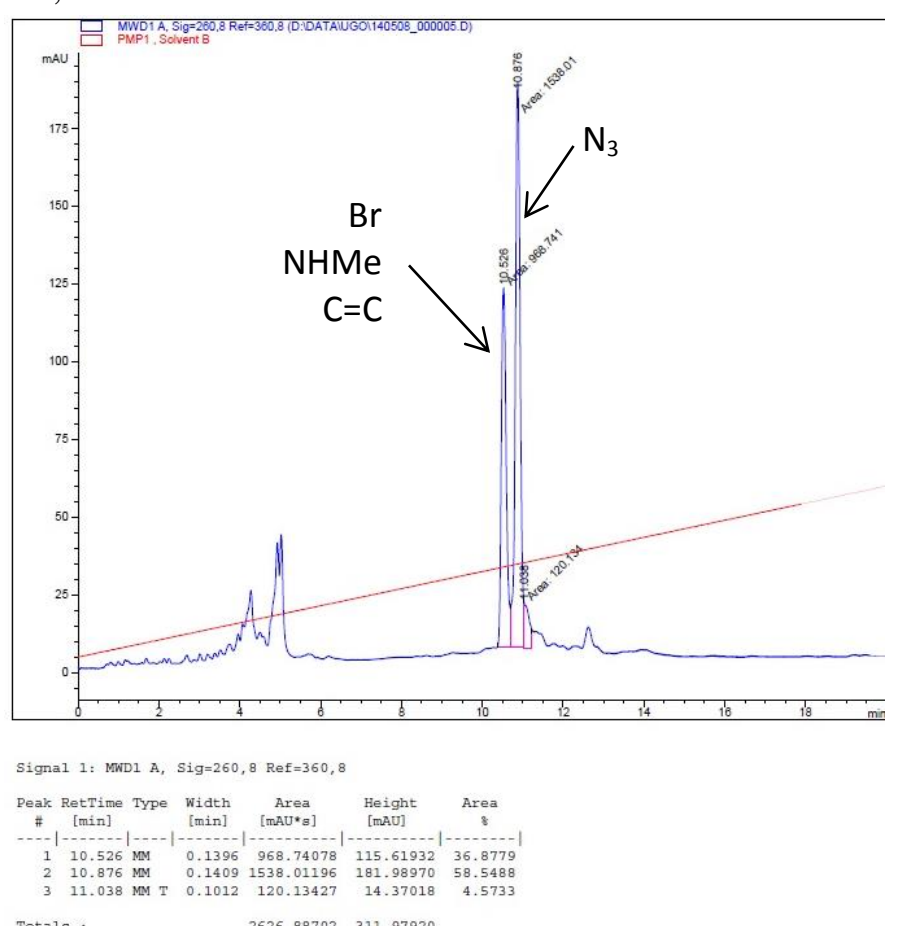

Totals :

$4 \mathrm{~h}, 45^{\circ} \mathrm{C}$

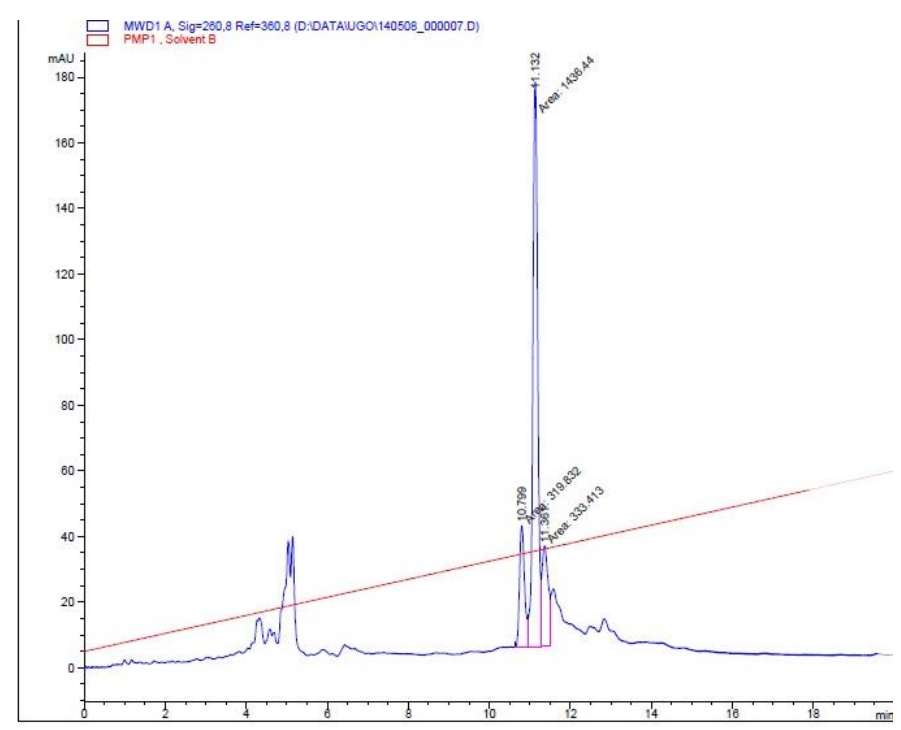

Signal 1: MWD1 A, Sig $=260,8$ Ref $=360,8$

Peak RetTime TYpe width

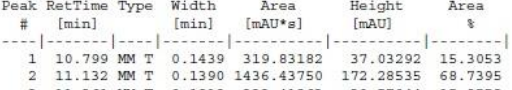

$\begin{array}{lllllll}3 & 11.361 & \text { MM T } & 0.1818 & 333.41263 & 30.57044 & 15.955\end{array}$

$2089.68195 \quad 239.88872$

$2 \mathrm{~h}, 45^{\circ} \mathrm{C}$

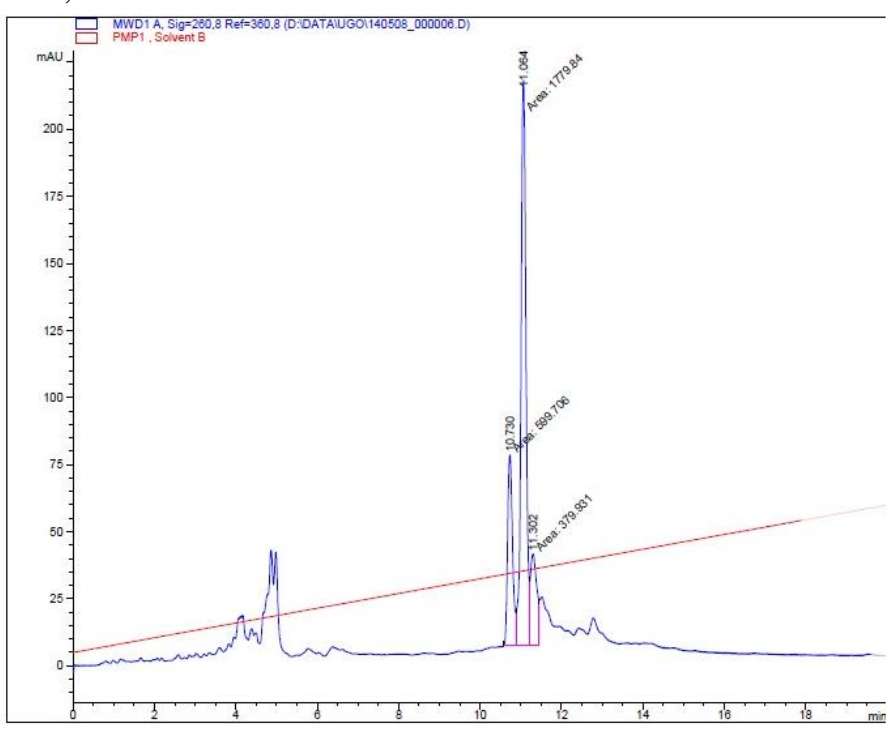

Signal 1: MWD1 A, Sig $=260,8$ Ref $=360,8$

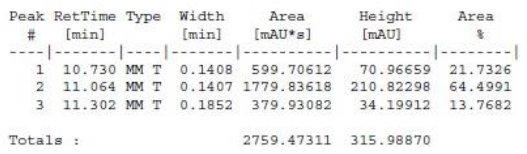

$8 \mathrm{~h}, 45^{\circ} \mathrm{C}$

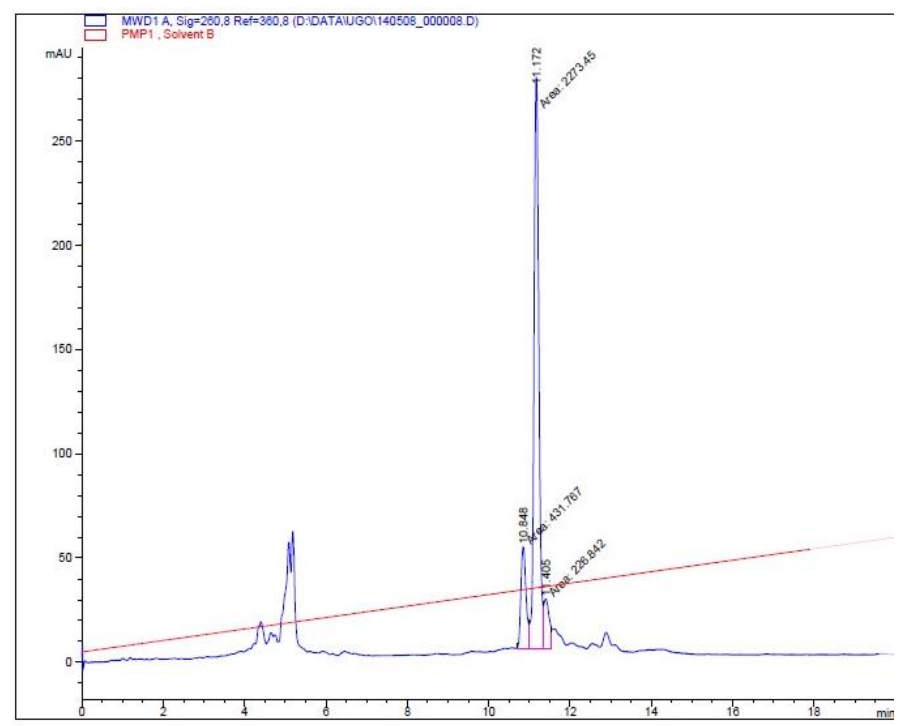

Signal 1: MWD1 A, Sig $=260,8$ Ref $=360,8$

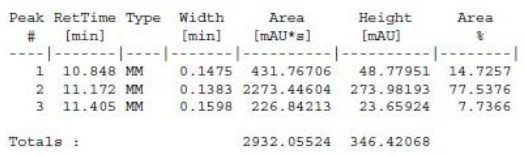

7 


\subsection{Azidation of 3'-Br-pre-miR-21 in harsher conditions}

\section{Experimental procedure}

8 solutions were prepared for these experiments directly prior use:

- Solution 1: $1.3 \mathrm{mg}$ of $\mathrm{NaN}_{3}$ in $400 \mu \mathrm{L}$ of DMF.

- $\quad$ Solution 2: $3 \mathrm{mg}$ of $\mathrm{NaI}$ in $400 \mu \mathrm{L}$ of DMF.

- Solution 3: $0.65 \mathrm{mg}$ of $\mathrm{NaN}_{3}$ in $65 \mu \mathrm{L}$ of DMF.

- Solution 4: $1.5 \mathrm{mg}$ of $\mathrm{NaI}$ in $65 \mu \mathrm{L}$ of DMF.

- Solution 5: Commercial solution $\mathrm{LiN}_{3} 20 \%$ wt in $\mathrm{H}_{2} \mathrm{O}$.

- Solution 6: $1.34 \mathrm{mg}$ of LiI in 397.5 $\mu \mathrm{L}$ of DMF.

- Solution 7: $3.25 \mathrm{mg}$ of $\mathrm{NaN}_{3}$ in $200 \mu \mathrm{L}$ of DMF.

- $\quad$ Solution 8: $7.5 \mathrm{mg}$ of $\mathrm{NaI}$ in $200 \mu \mathrm{L}$ of DMF.

5 CPG columns (5 mg of 1000Å, $50 \mathrm{nmol}$ syntheses) with the sequence of pre-miR-21 (5'CAGCUUAUCAGACUGAUGUUGACUGUUGAAUCUCAUGGCAACACCAGUCGAUGGGCUGUC $\left.\mathrm{Br}_{\mathrm{Br}}\right)\left(\mathrm{C}_{\mathrm{Br}}: 2^{\prime}-\right.$ $O$-methylenetriazolo-bromobutane) were prepared. CPGs were combined and mixed in an Eppendorf tube before being equally redistributed into 5 Eppendorf tubes. Respective azide and iodide solutions were added. The reaction mixtures were shaken vigorously for $6 \mathrm{~h}$ on an Eppendorf shaker at the corresponding temperature and the CPGs filtered and washed successively with $1 \mathrm{~mL}$ of DMF and acetonitrile. After cleavage from the solid support and RNA deprotection (aq. $\mathrm{MeNH}_{2} / \mathrm{NH}_{4} \mathrm{OH}$, TEA.HF), the composition of the crude solution was evaluated by integration of peaks in the HPLC chromatograms (see following spectra).

\section{Conditions:}

- Conditions A (control experiment): $\left[\mathrm{NaN}_{3}\right]=25 \mathrm{mM},[\mathrm{NaI}]=25 \mathrm{mM}, 45^{\circ} \mathrm{C} .200 \mu \mathrm{L}$ of solution 1 and $200 \mu \mathrm{L}$ of solution 2.

- Conditions B (increased concentration): $\left[\mathrm{NaN}_{3}\right]=75 \mathrm{mM},[\mathrm{NaI}]=75 \mathrm{mM}, 45^{\circ} \mathrm{C} .65 \mu \mathrm{L}$ of solution 3 and 65 $\mu$ Lof solution 4.

- Conditions C (lithium counter-ion): $\left[\mathrm{LiN}_{3}\right]=25 \mathrm{mM},[\mathrm{LiI}]=25 \mathrm{mM}, 45^{\circ} \mathrm{C} .2 .45 \mu \mathrm{L}$ of solution 5 and $397.5 \mu \mathrm{L}$ of solution 6 .

- Conditions D (increased equivalence): $\left[\mathrm{NaN}_{3}\right]=125 \mathrm{mM},[\mathrm{NaI}]=125 \mathrm{mM}, 45^{\circ} \mathrm{C} .200 \mu \mathrm{L}$ of solution 7 and 200 $\mu \mathrm{L}$ of solution 8 .

- Conditions E (increased temperature): $\left[\mathrm{NaN}_{3}\right]=25 \mathrm{mM},[\mathrm{NaI}]=25 \mathrm{mM}, 65^{\circ} \mathrm{C} .200 \mu \mathrm{L}$ of solution 1 and $200 \mu \mathrm{L}$ of solution 2 . 


\section{HPLC-profile of crude 3 '- $\mathrm{N}_{3}$-pre-miR-21}

\section{Conditions A (control experiment)}

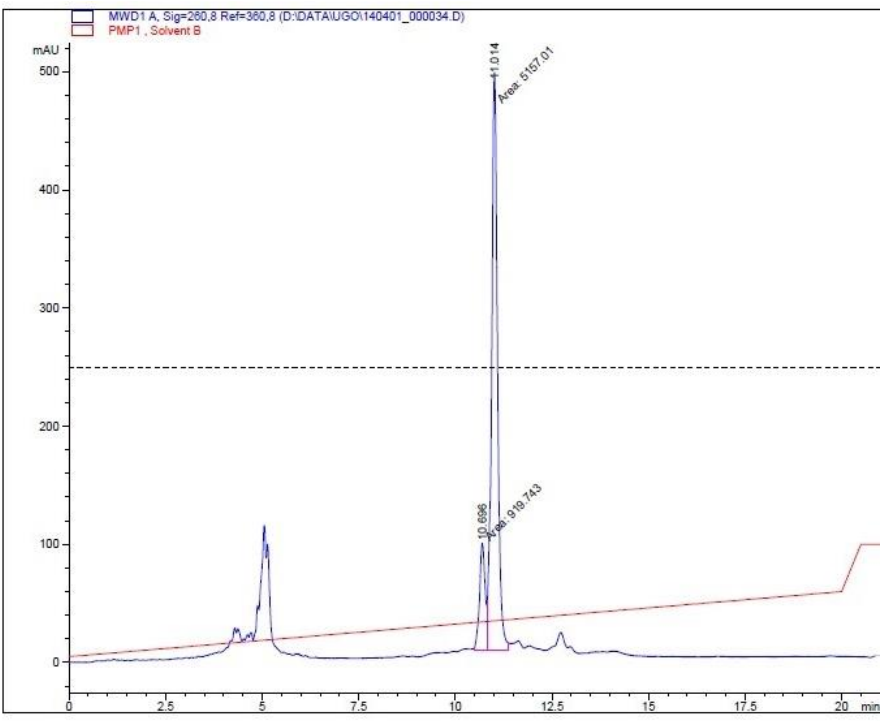

Signal 1: MND1 A, Sig $=260,8$ Ref $=360,8$

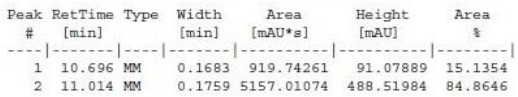

2 . 11.014 Mat 0.175

\section{Conditions C (lithium counter-ion)}

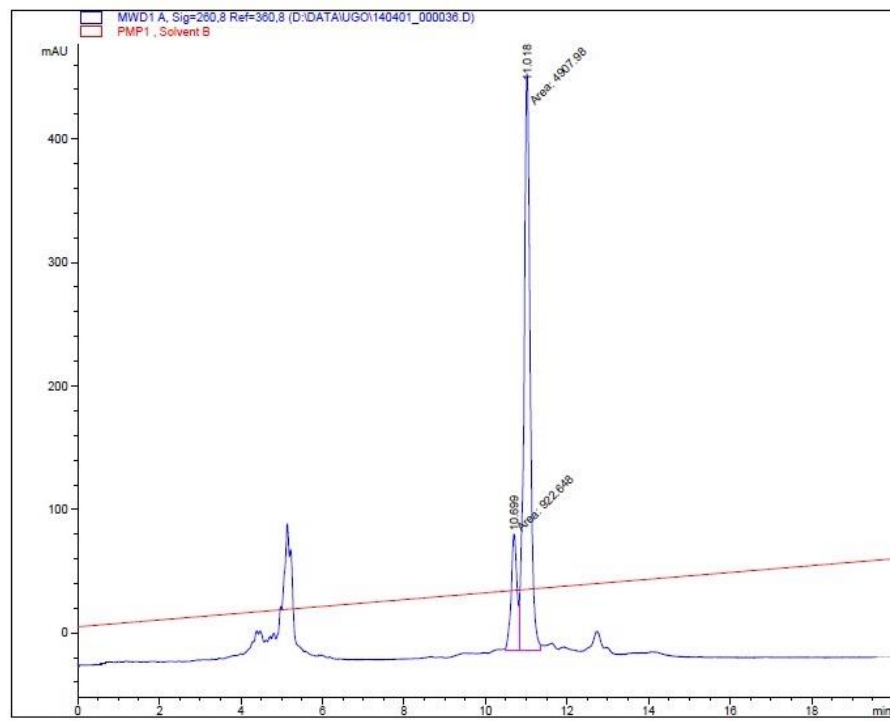

Signal 1: MND1 A, Sig $=260,8$ Ref $=360,8$

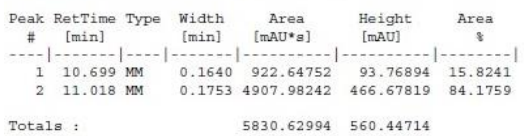

Conditions B (increased concentration)

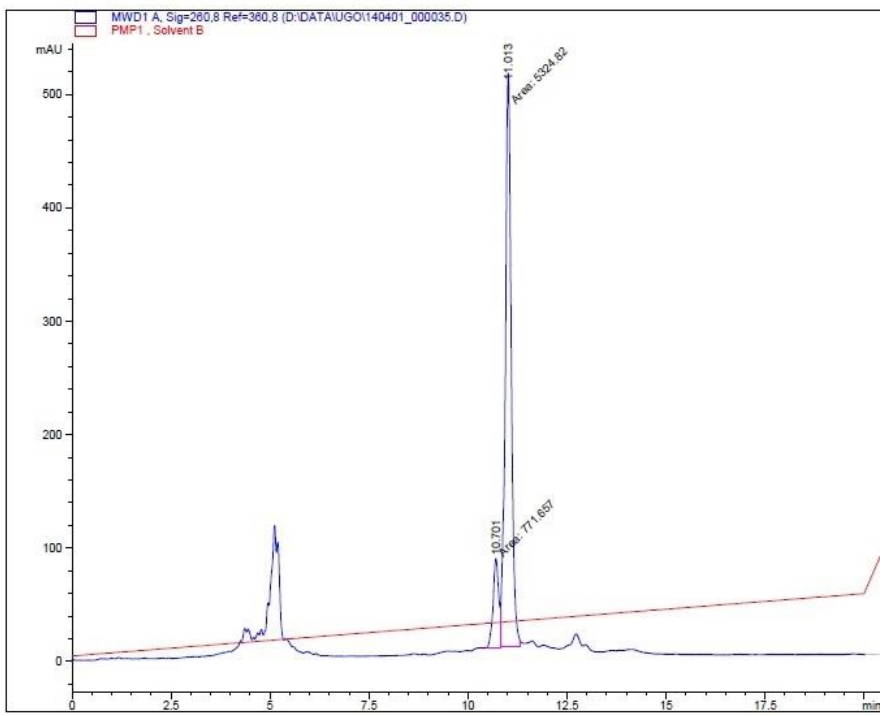

Signal 1: MWD1 A, Sig $=260,8$ Ref $=360,8$

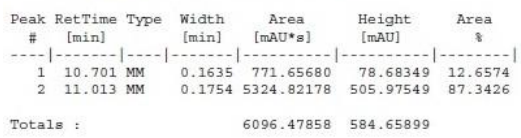

Tota1s : $\quad 6096.47858 \quad 584.65899$

\section{Conditions D (increased equivalence)}

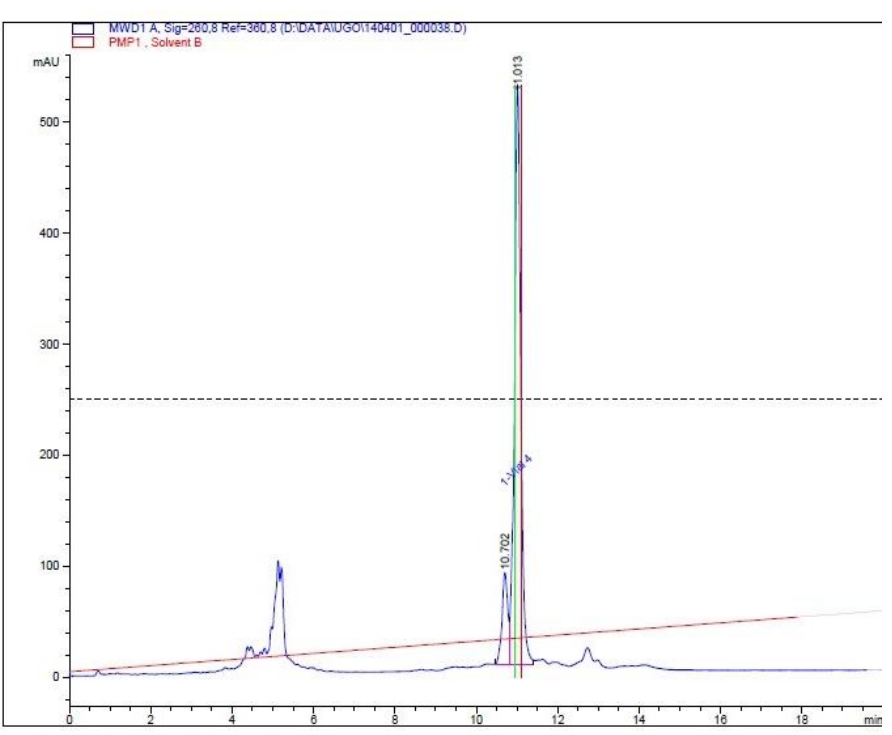

Signal 1: MWD1 A, Sig $=260,8$ Ref $=360,8$

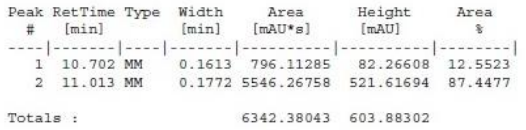


Conditions E (increased temperature)
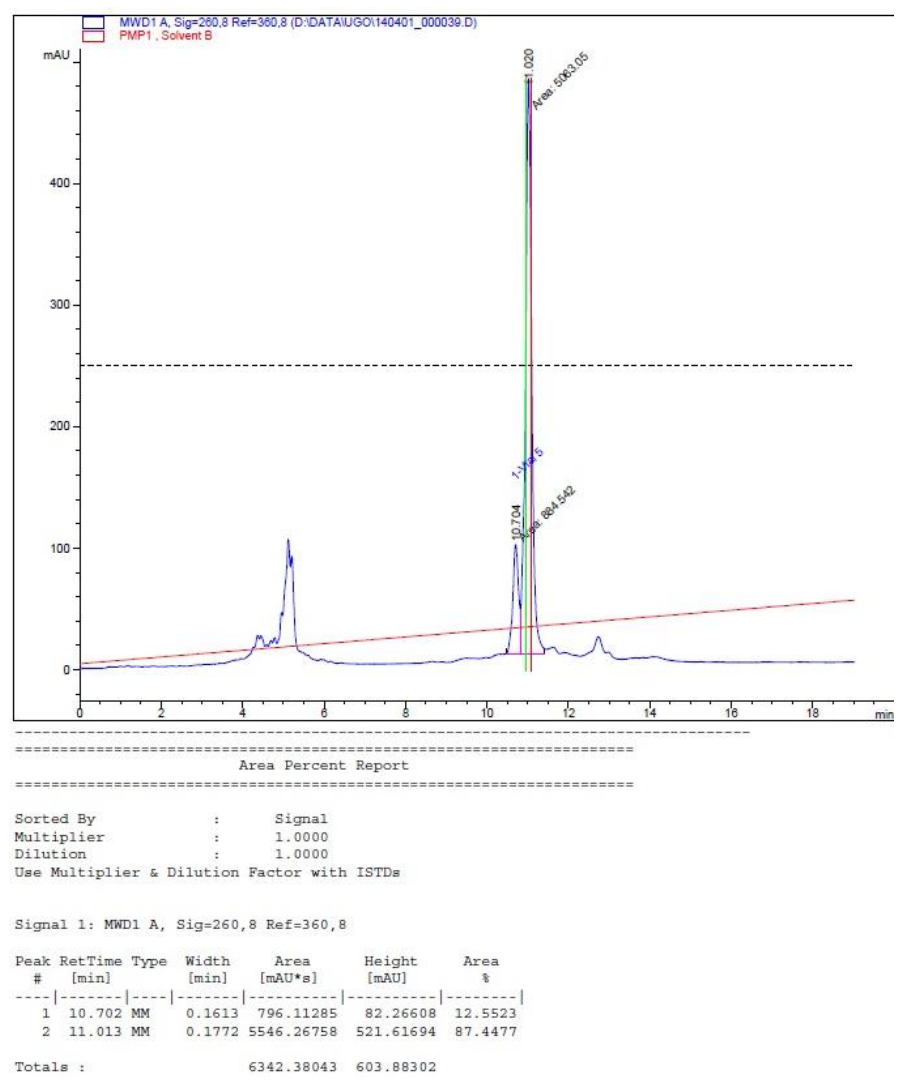

6342.38043603 .88302

10 


\subsection{Azidation of 3'-Br-pre-miR-21 with and without NaI}

\section{Experimental procedure}

2 solutions were prepared for these experiments directly prior use:

- Solution 1: $2.6 \mathrm{mg}$ of $\mathrm{NaN}_{3}$ in $440 \mu \mathrm{L}$ of DMF.

- $\quad$ Solution 2: $6 \mathrm{mg}$ of $\mathrm{NaI}$ in $80 \mu \mathrm{L}$ of DMF.

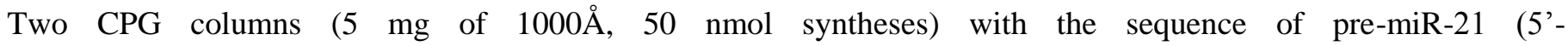
CAGCUUAUCAGACUGAUGUUGACUGUUGAAUCUCAUGGCAACACCAGUCGAUGGGCUGUC $\left.\mathrm{Br}_{\mathrm{Br}}\right)\left(\mathrm{C}_{\mathrm{Br}}: 2^{\prime}-\right.$ $O$-methylenetriazolo-bromobutane) were prepared. CPGs were combined and mixed in an Eppendorf tube before being equally redistributed into 4 Eppendorf tubes. Sodium azide $\left(110 \mu \mathrm{L}\right.$ of solution 1 , final $\left.\left[\mathrm{NaN}_{3}\right]=75 \mathrm{mM}\right)$ was added to both samples while sodium iodide $(20 \mu \mathrm{L}$ of solution 2 , final $[\mathrm{NaI}]=75 \mathrm{mM})$ was only added to one sample. The reaction mixture was shaken vigorously for $3 \mathrm{~h}$ at $45^{\circ} \mathrm{C}$ on an Eppendorf shaker. Solution were added a second time as described previously, the reaction mixtures shaken vigorously for $3 \mathrm{~h}$ at $45^{\circ} \mathrm{C}$ and the CPGs filtered and washed successively with $1 \mathrm{~mL}$ of DMF and acetonitrile. After cleavage from the solid support and RNA deprotection (aq. $\mathrm{MeNH}_{2} / \mathrm{NH}_{4} \mathrm{OH}$, TEA.HF), the crude solution was evaluated by integration of peaks in the HPLC chromatograms (see following spectra).

\section{HPLC-profile of crude 3'-N ${ }_{3}$-pre-miR-21}

With NaI
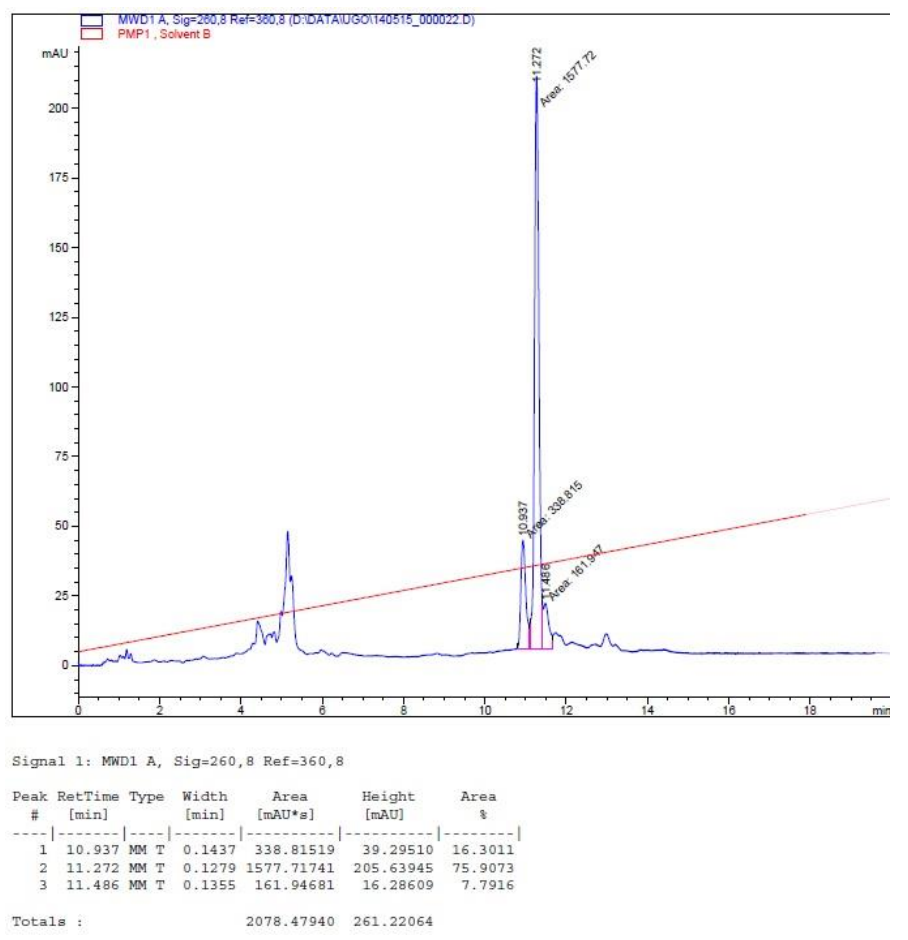

Without NaI

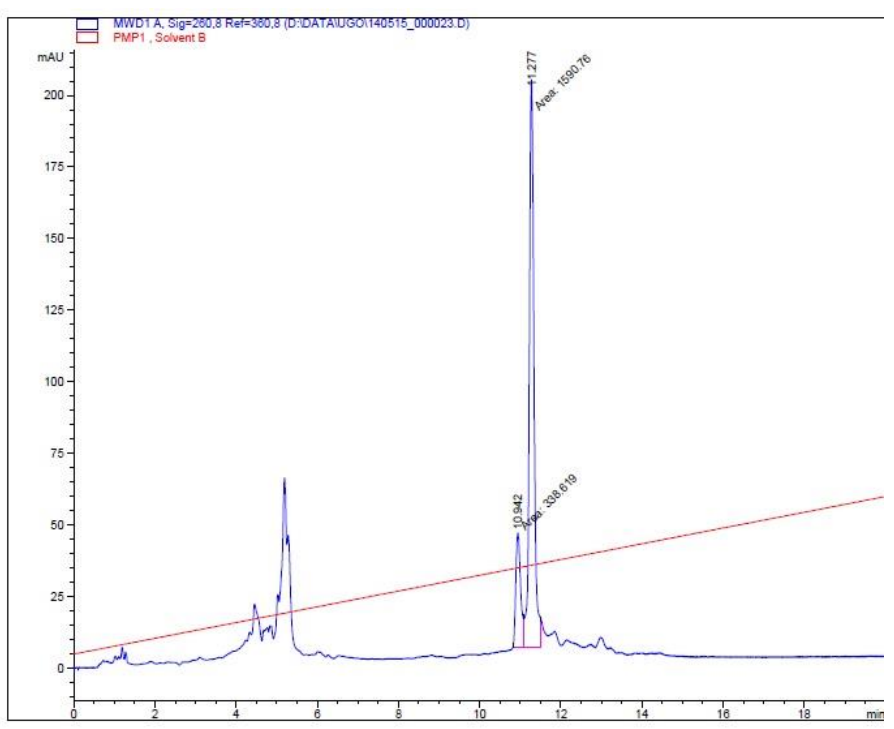

Signal 1: MND1 A, Sig $=260,8$ Ref $=360,8$

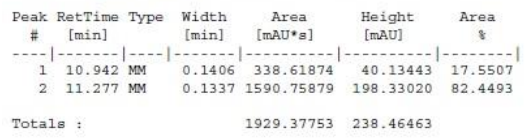




\subsection{Azidation of 3'-Br-pre-miR-21 in various solvents}

\section{Experimental procedure}

3 solutions were prepared for these experiments directly prior use:

- Solution 1: $0.65 \mathrm{mg}$ of $\mathrm{NaN}_{3}$ in $110 \mu \mathrm{L}$ of THF.

- Solution 2: $0.65 \mathrm{mg}$ of $\mathrm{NaN}_{3}$ in $110 \mu \mathrm{L}$ of DMSO.

- Solution 3: $0.65 \mathrm{mg}$ of $\mathrm{NaN}_{3}$ in $110 \mu \mathrm{L}$ of EtOH.

2 CPG columns (5 mg of 1000A, $50 \mathrm{nmol}$ syntheses) with the sequence of pre-miR-21 (5'CAGCUUAUCAGACUGAUGUUGACUGUUGAAUCUCAUGGCAACACCAGUCGAUGGGCUGUC $\left.\mathrm{Br}_{\mathrm{Br}}\right)\left(\mathrm{C}_{\mathrm{Br}}: 2^{\prime}-\right.$ $O$-methylenetriazolo-bromobutane) were prepared. CPGs were combined and mixed in an Eppendorf tube before being equally redistributed into 3 Eppendorf tubes. Sodium azide solutions $\left(110 \mu \mathrm{L}\right.$, end $\left.\left[\mathrm{NaN}_{3}\right]=75 \mathrm{mM}\right)$ were added. The reaction mixture was shaken vigorously for $6 \mathrm{~h}$ at $45^{\circ} \mathrm{C}$ on an Eppendorf shaker, filtered and washed successively with $1 \mathrm{~mL}$ of DMF and acetonitrile. After cleavage from the solid support and RNA deprotection (aq. $\mathrm{MeNH}_{2} / \mathrm{NH}_{4} \mathrm{OH}$, TEA.HF), the composition of the crude solution was evaluated by integration of peaks in the HPLC chromatograms (see following spectra). 
HPLC-profile of crude 3 '-N $\mathrm{N}_{3}$-pre-miR-21

In THF

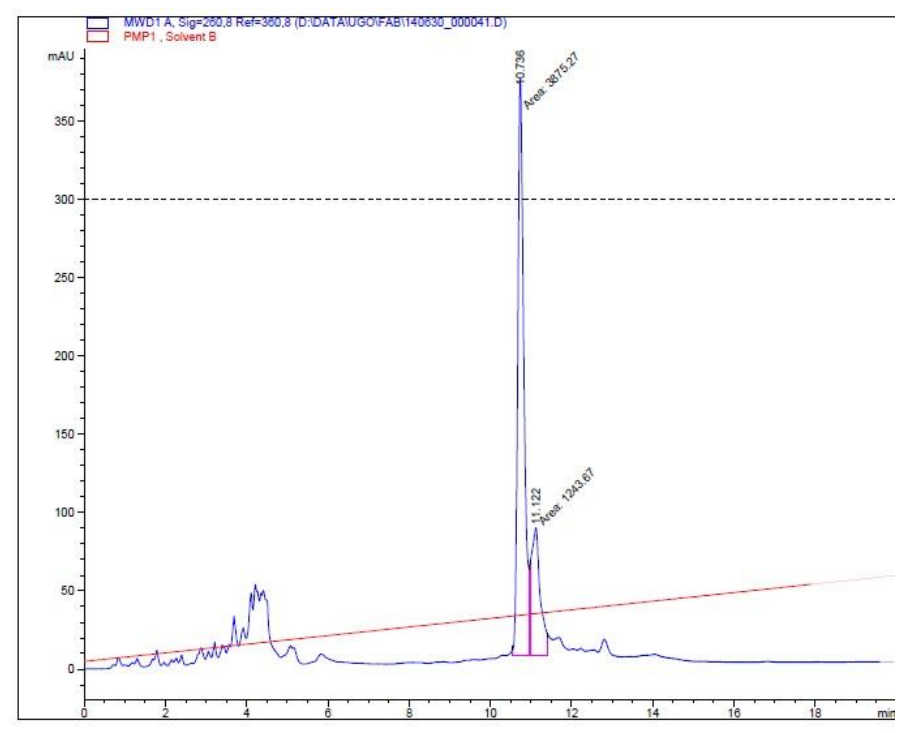

Signal 1: MWD1 A, Sig $=260,8$ Ref $=360,8$

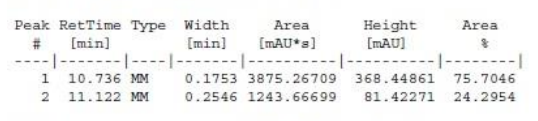

Totals : $\quad 5118.93408 \quad 449.87132$

In $\mathrm{EtOH}$

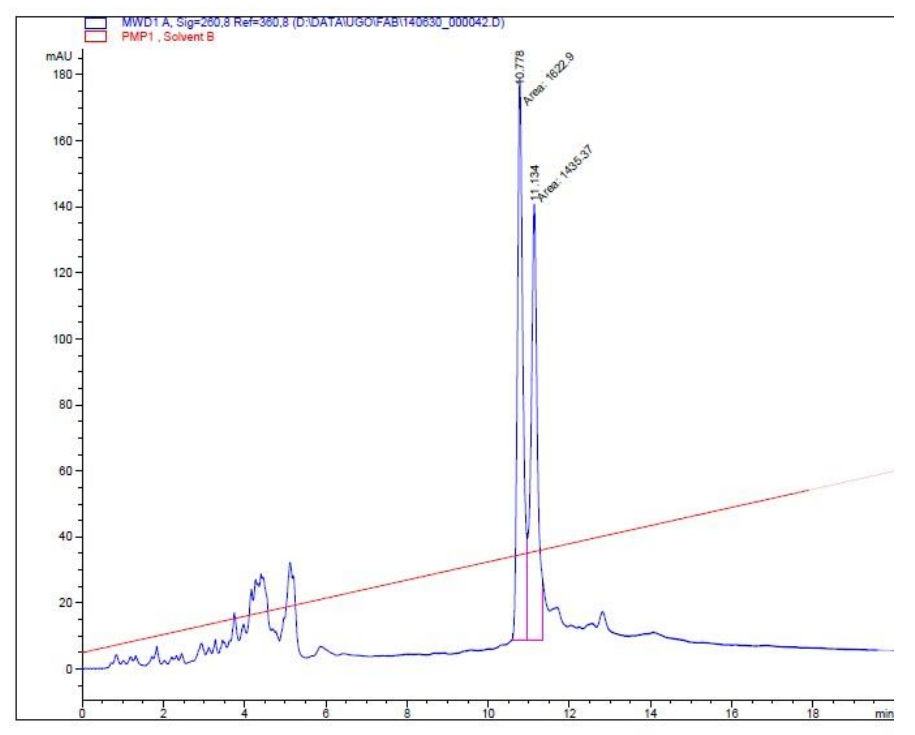

Signa1 1: MWD1 A, Sig $=260,8$ Ref $=360,8$

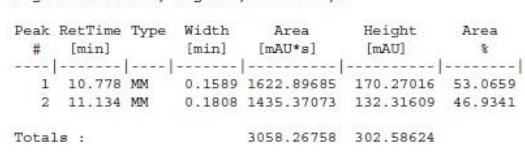

In DMSO
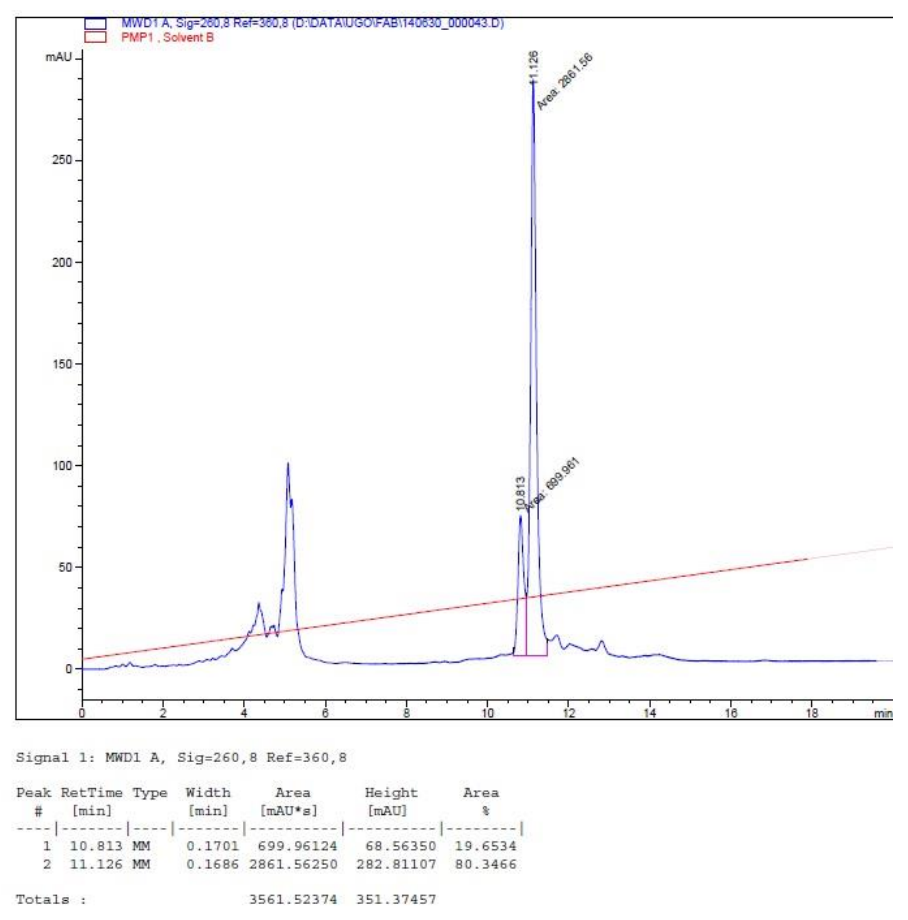

13 


\section{Optimization of reverse-click reaction in solution phase on pre-miR-21}

\section{Experimental procedure}

4 solutions were prepared for these experiments directly prior use:

- Solution 1: THPTA [50mM]: $1.1 \mathrm{mg}$ of THPTA in $50 \mu \mathrm{L}$ of water.

- Solution 2: Cy5 alkyne [20mM]: $1.18 \mathrm{mg}$ of Cy5 alkyne in $100 \mu \mathrm{L}$ of DMF.

- Solution 3: $\mathrm{CuSO}_{4} .5 \mathrm{H}_{2} \mathrm{O}[20 \mathrm{mM}]: 5 \mathrm{mg}$ of $\mathrm{CuSO}_{4} .5 \mathrm{H}_{2} \mathrm{O}$ in $1 \mathrm{~mL}$ of water.

- Solution 4: $\mathrm{Na}$ ascorbate [100mM]: $20 \mathrm{mg}$ of $\mathrm{Na}$ ascorbate in $1 \mathrm{~mL}$ of water.

To a water solution of $5^{\prime}$ - $\mathrm{N}_{3}$-pre-miR-21 (10 $\left.\mu \mathrm{L}, 1 \mathrm{nmol}\right)$ with the sequence (5'$\mathrm{C}_{\mathrm{N} 3}$ CAGCUUAuCAGACUGAUGUUGACUGUUGAaUCUCAUGGCAACACCAGUCGAUGGGCUGU) (C $\mathrm{C}_{\mathrm{N} 3}$ : 2'$O$-methylenetriazolo-azidobutane) was successively added water $(15 \mu \mathrm{L})$, PBS buffer $(\mathrm{pH}=7.4,28.5 \mu \mathrm{L})$, THPTA (solution 1, $2.5 \mu \mathrm{L}$, end [2.1mM]), Cy5 alkyne (solution 2, $1.25 \mu \mathrm{L}$, end [0.8mM]), $\mathrm{CuSO}_{4} .5 \mathrm{H}_{2} \mathrm{O}$ (solution 3, $1.25 \mu \mathrm{L}$, end $[0.8 \mathrm{mM}]$ ) and $\mathrm{Na}$ ascorbate (solution $4,2.5 \mu \mathrm{L}$, end $[4.2 \mathrm{mM}]$ ). After incubation of the reaction mixture for the reported time and at the reported temperature, the solution was cooled down to room temperature. Water $(150 \mu \mathrm{L})$ was added and the solution extracted three times with $200 \mu \mathrm{L}$ of EtOAc. NaOAC ( $25 \mu \mathrm{L}$ of a $3 \mathrm{M}$ solution) and 800 $\mu \mathrm{L}$ of a 2:1 EtOH/iPrOH mixture were added and RNA was precipitated for $30 \mathrm{~min}$ at $-80^{\circ} \mathrm{C}$ (alternatively, $-20^{\circ} \mathrm{C}$ can be used for $12 \mathrm{~h}$ ). After centrifugation (10min, 14000rpm), supernatant was removed and the RNA pellets dissolved in water $(200 \mu \mathrm{L})$ for HPLC purification (see following spectra).

\section{HPLC profiles of crude 5'-Cy5-pre-miR-21}

$1 \mathrm{~h}$ at $25^{\circ} \mathrm{C}$

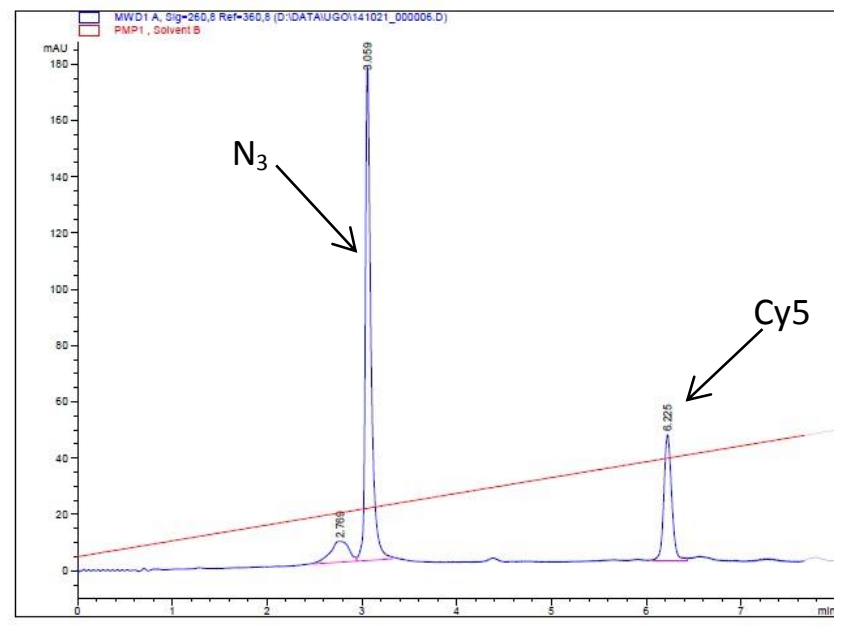

Signal 1: MWD1 A, Sig $=260,8$ Ref $=360,8$

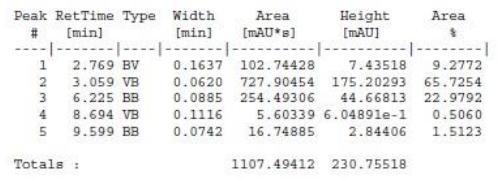

$3 \mathrm{~h}$ at $25^{\circ} \mathrm{C}$
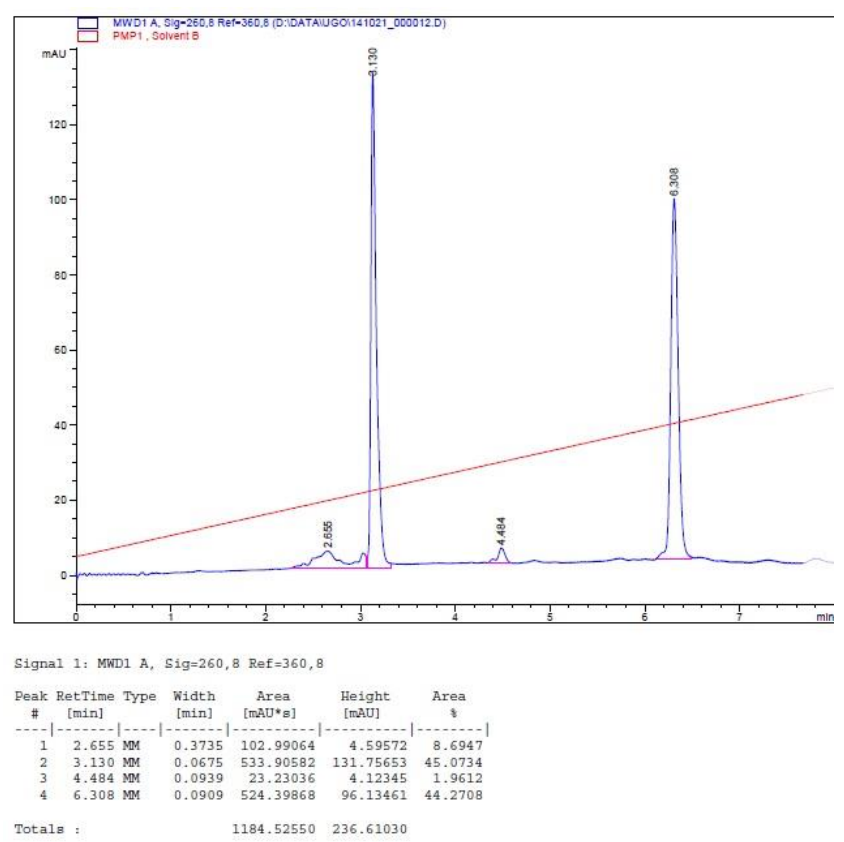
$1 \mathrm{~h}$ at $45^{\circ} \mathrm{C}$

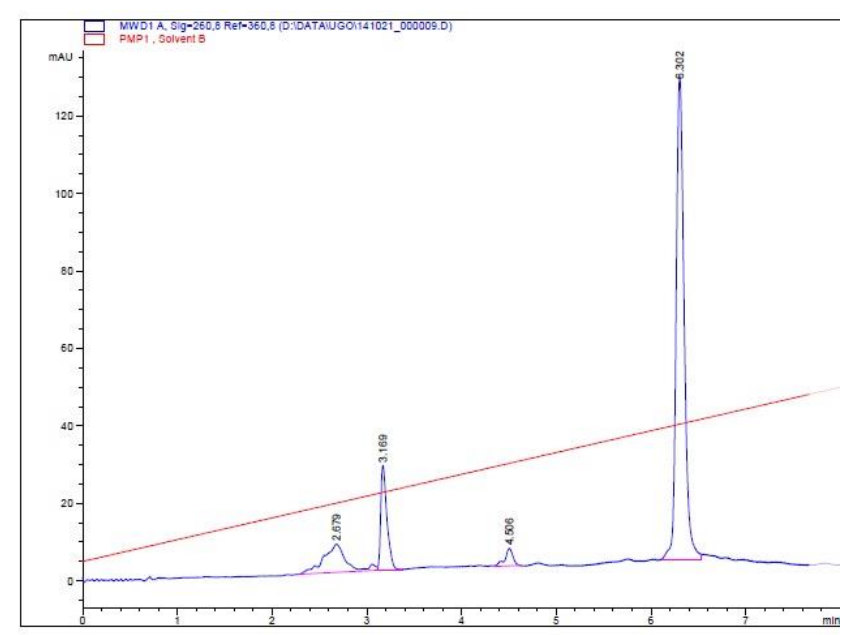

Signa1 1: MWD1 A, Sig $=260,8$ Ref $=360,8$

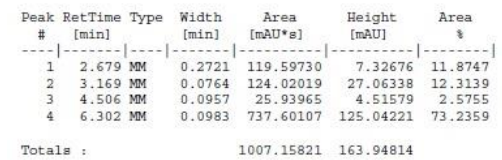

\section{HPLC profiles of crude 3'-Cy5-pre-miR-21}

$2 \mathrm{~h}$ at $45^{\circ} \mathrm{C}$

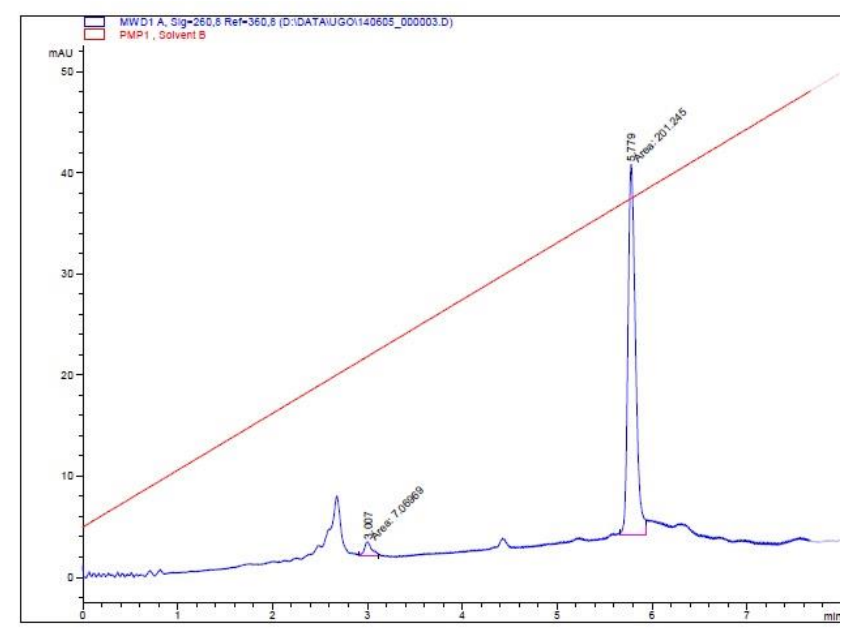

Signa1 1: MWD1 A, Sig $=260,8$ Ref $=360,8$

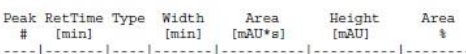

$\begin{array}{lllllll}1 & 3.007 \mathrm{MM} & 0.0881 & 7.06969 & 1.33799 & 3.3938 \\ 2 & 5.779 \mathrm{MM} & 0.0916 & 201.24489 & 36.61101 & 96.6062\end{array}$

Totals : $\quad 208.31458 \quad 37.94901$
$2 \mathrm{~h}$ at $45^{\circ} \mathrm{C}$

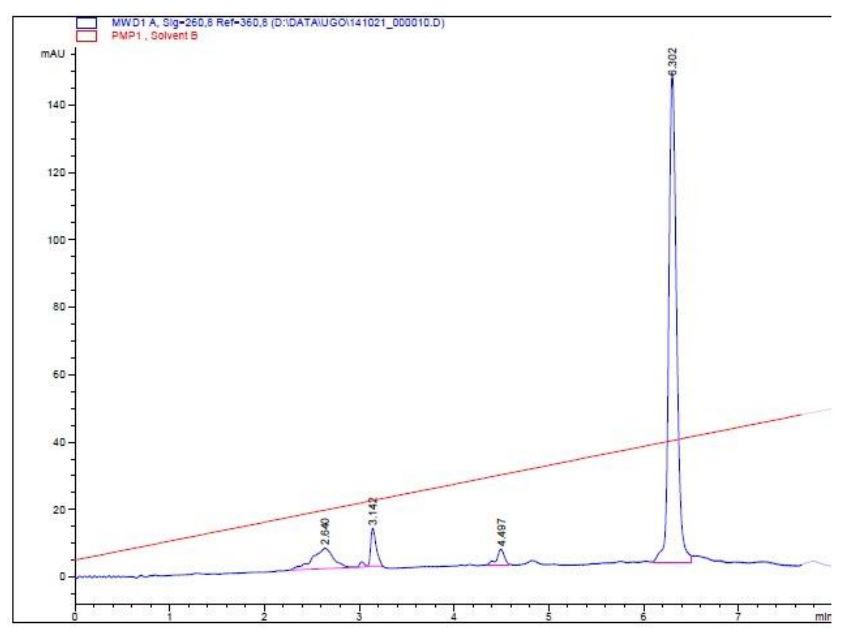

Signa1 1: MWD1 A, Sig=260, 8 Ref $=360,8$

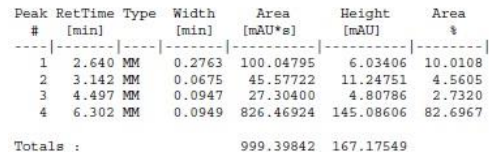

Tota1s :

$999.39842 \quad 167.17549$ 


\section{Evaluation of reverse-click reaction on solid support on pre-miR-21 in different conditions}

\section{Experimental procedure}

7 solutions were prepared for these experiments directly prior use:

- Solution 1: $\mathrm{CuSO}_{4} .5 \mathrm{H}_{2} \mathrm{O}[5 \mathrm{mM}]$ in $\mathrm{H}_{2} \mathrm{O}: 12.5 \mathrm{mg}$ of $\mathrm{CuSO}_{4} .5 \mathrm{H}_{2} \mathrm{O}$ in $10 \mathrm{~mL}$ of water.

- Solution 2: $\mathrm{Na}$ ascorbate $[50 \mathrm{mM}]$ in $\mathrm{H}_{2} \mathrm{O}: 10 \mathrm{mg}$ of $\mathrm{Na}$ ascorbate in $1 \mathrm{~mL}$ of water.

- $\quad$ Solution 3: TBTA [50 mM] in DMF: $2.7 \mathrm{mg}$ of TBTA in $100 \mu \mathrm{L}$ of DMF.

- Solution 4: THPTA [50 mM] in DMF: $2.2 \mathrm{mg}$ of THPTA in $100 \mu \mathrm{L}$ of DMF.

- Solution 5: $\mathrm{H}_{2} \mathrm{O} / \mathrm{MeOH}(1: 1): 5 \mathrm{~mL}$ of $\mathrm{H}_{2} \mathrm{O}, 5 \mathrm{~mL}$ of $\mathrm{MeOH}$.

- Solution 6: PBS buffer/MeOH (1:1): $5 \mathrm{~mL}$ of PBS buffer, $5 \mathrm{~mL}$ of MeOH.

- $\quad$ Solution 7: Cy3 alkyne [50 mM] in DMF: $3.4 \mathrm{mg}$ of Cy3 azide in $120 \mu \mathrm{L}$ of DMF.

- Solution 8: Tris base [1M] in water: $121 \mathrm{mg}$ of Tris in $1 \mathrm{~mL}$ of water

- Solution 9: $\mathrm{NaN}_{3}[400 \mathrm{mM}]: 4.55 \mathrm{mg}$ of $\mathrm{NaN}_{3}$ in $770 \mu \mathrm{L}$ of DMF.

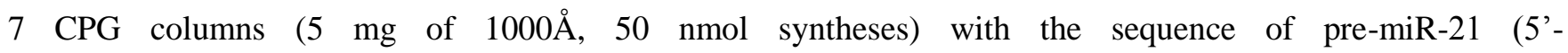
$\mathrm{C}_{\mathrm{Br}}$ AgCuUAuCAGACUGAUGUUGACUGUUGAAUCUCAUGGCAACACCAGUCGAUGGGCUGUC) were prepared. CPGs were transferred into 7 Eppendorf tubes and were suspended in a DMF solution of sodium azide (110 $\mu \mathrm{L}$ of solution 9). The reaction mixture was shaken vigorously for $6 \mathrm{~h}$ at $45^{\circ} \mathrm{C}$ on an Eppendorf shaker. The CPG was filtered and washed successively with $1 \mathrm{~mL}$ of DMF and acetonitrile. CPGs were combined and mixed in an Eppendorf tube before being equally redistributed into 7 Eppendorf tubes and successfully added solvent $\left(\mathrm{H}_{2} \mathrm{O} / \mathrm{MeOH}\right.$ or PBS buffer/MeOH), DMF, ligand (TBTA or THPTA), Cy3 alkyne, Na ascorbate and copper sulfate. The reaction mixture was shaken vigorously for $16 \mathrm{~h}$ on an Eppendorf shaker and the CPGs filtered and washed successively with $1 \mathrm{~mL}$ of DMF, 0.1N aq. EDTA pH 8, DMF, and acetonitrile. After cleavage from the solid support and RNA deprotection (aq. $\mathrm{MeNH}_{2} / \mathrm{NH}_{4} \mathrm{OH}$, TEA.HF), the composition of the crude solution was evaluated by integration of peaks in the HPLC chromatograms (see following spectra).

Conditions:

- Condition A (Control): $10 \mu \mathrm{L}$ of solution $1,10 \mu \mathrm{L}$ of solution $2,10 \mu \mathrm{L}$ of solution $3,300 \mu \mathrm{L}$ of solution 5, 20 $\mu \mathrm{L}$ of solution $7,50 \mathrm{uL}$ of DMF.

- Condition B (Catalyst /5): $2 \mu \mathrm{L}$ of solution $1,2 \mu \mathrm{L}$ of solution $2,2 \mu \mathrm{L}$ of solution $3,300 \mu \mathrm{L}$ of solution 5,20 $\mu \mathrm{L}$ of solution 7, 50uL of DMF.

- Condition C (TBTA x5): $10 \mu \mathrm{L}$ of solution $1,10 \mu \mathrm{L}$ of solution 2, $50 \mu \mathrm{L}$ of solution 3, $300 \mu \mathrm{L}$ of solution 5 , $20 \mu \mathrm{L}$ of solution $7,50 \mathrm{uL}$ of DMF. 
- Condition D (THPTA): $10 \mu \mathrm{L}$ of solution $1,10 \mu \mathrm{L}$ of solution $2,50 \mu \mathrm{L}$ of solution $4,300 \mu \mathrm{L}$ of solution 5,20 $\mu \mathrm{L}$ of solution $7,50 \mathrm{uL}$ of DMF.

- Condition E (PBS buffer): $10 \mu \mathrm{L}$ of solution $1,10 \mu \mathrm{L}$ of solution $2,10 \mu \mathrm{L}$ of solution $3,300 \mu \mathrm{L}$ of solution 6 , $20 \mu \mathrm{L}$ of solution 7, 50uL of DMF.

- Condition F (TRIS base): $10 \mu \mathrm{L}$ of solution $1,10 \mu \mathrm{L}$ of solution $2,10 \mu \mathrm{L}$ of solution $3,300 \mu \mathrm{L}$ of solution 5 , $20 \mu \mathrm{L}$ of solution $7,10 \mu \mathrm{L}$ of solution $8,50 \mu \mathrm{L}$ of DMF.

\section{HPLC profiles of crude 5'-Cy3-pre-miR-21}

\section{Condition A (control)}
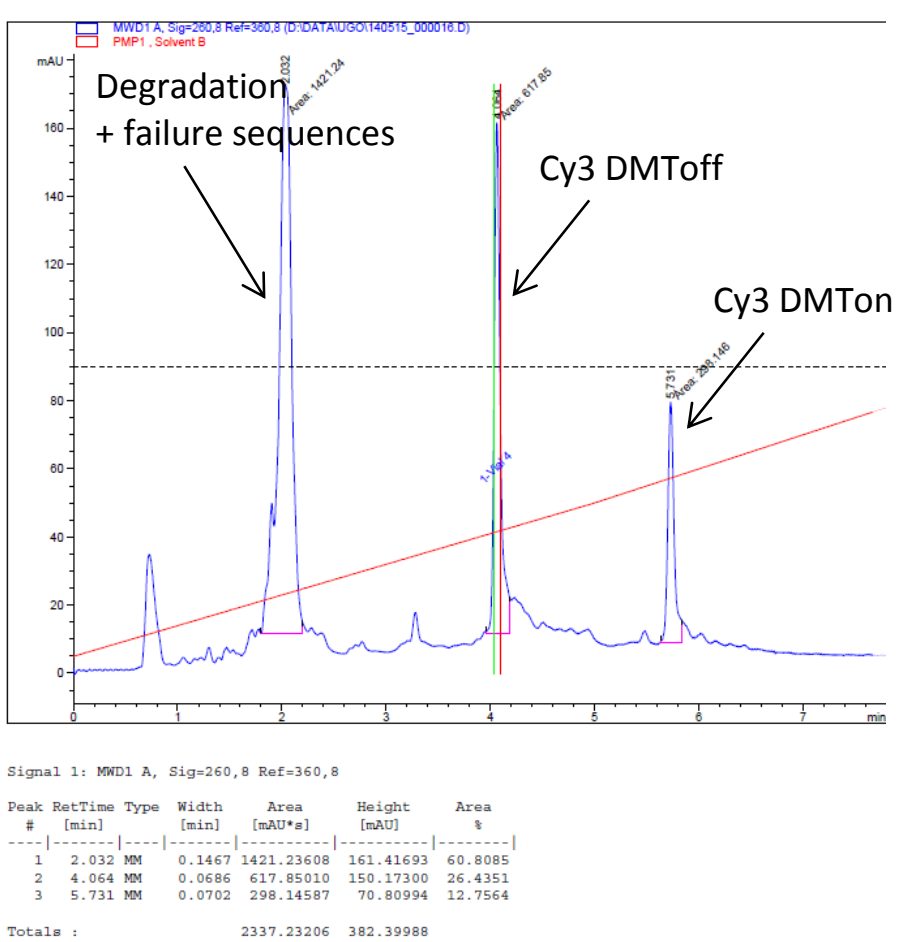

\section{Condition B (Catalyst /5)}
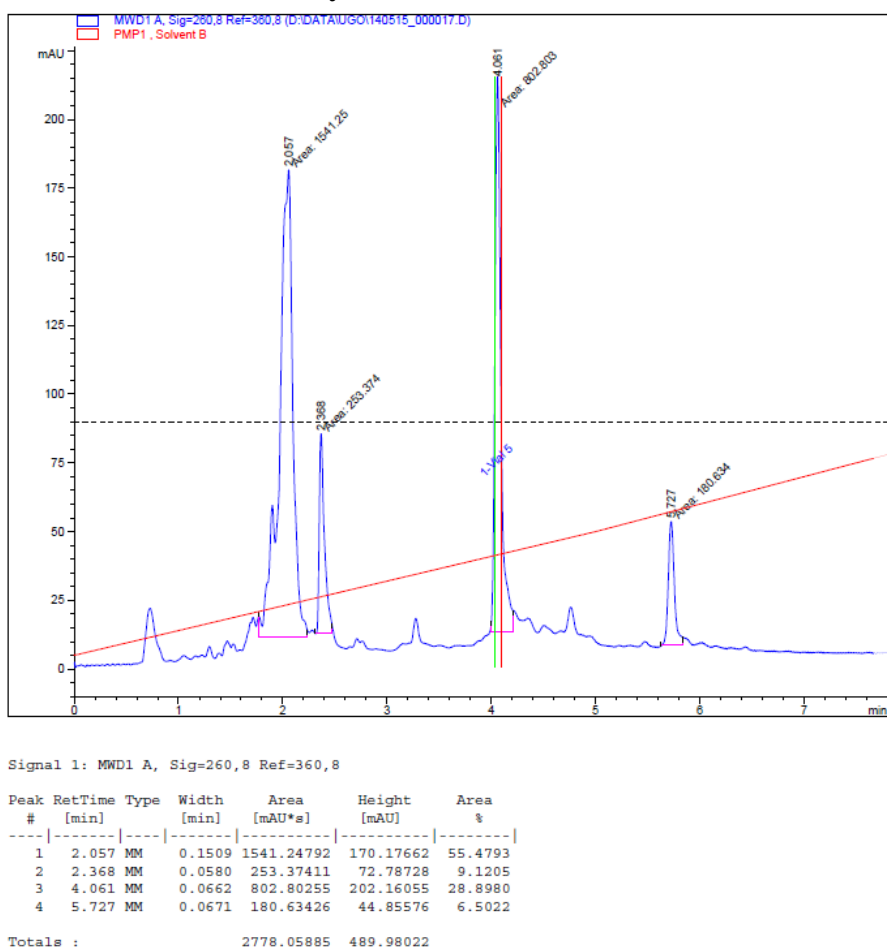


\section{Condition C (TBTA x5)}

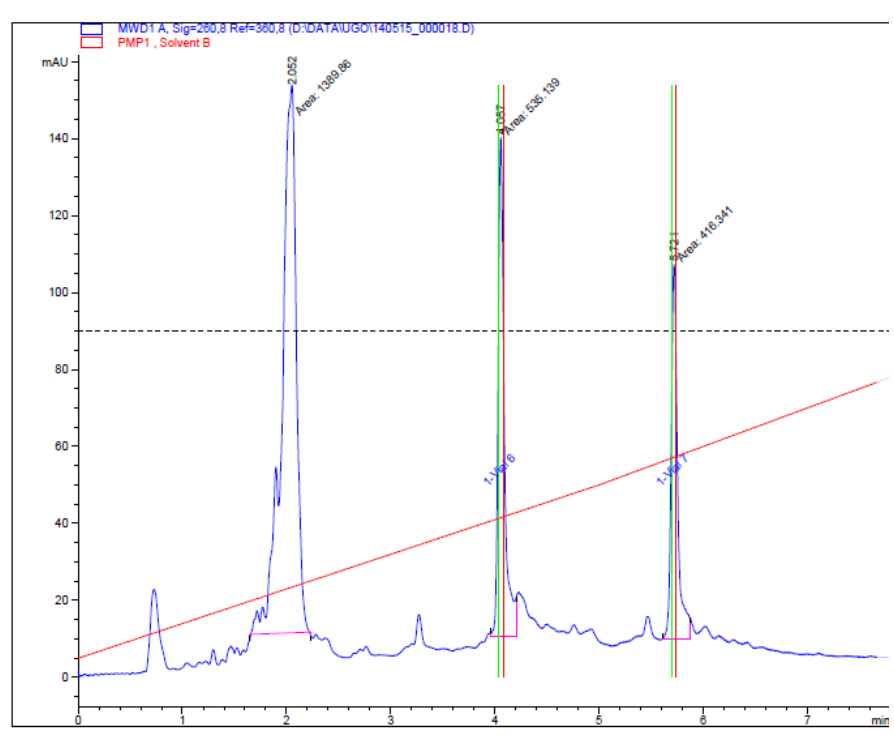

Signa1 1: MWD1 A, Sig $=260,8$ Ref $=360,8$

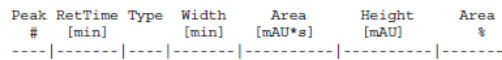

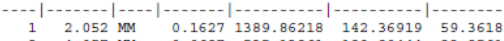

$\begin{array}{lllllll}4.057 & & 0.1627 & 0.0687 & 535.13861 & 129.80444 & 22.8561\end{array}$

Totals : $\quad 2341.34229 \quad 369.46851$

\section{Condition E (PBS buffer)}

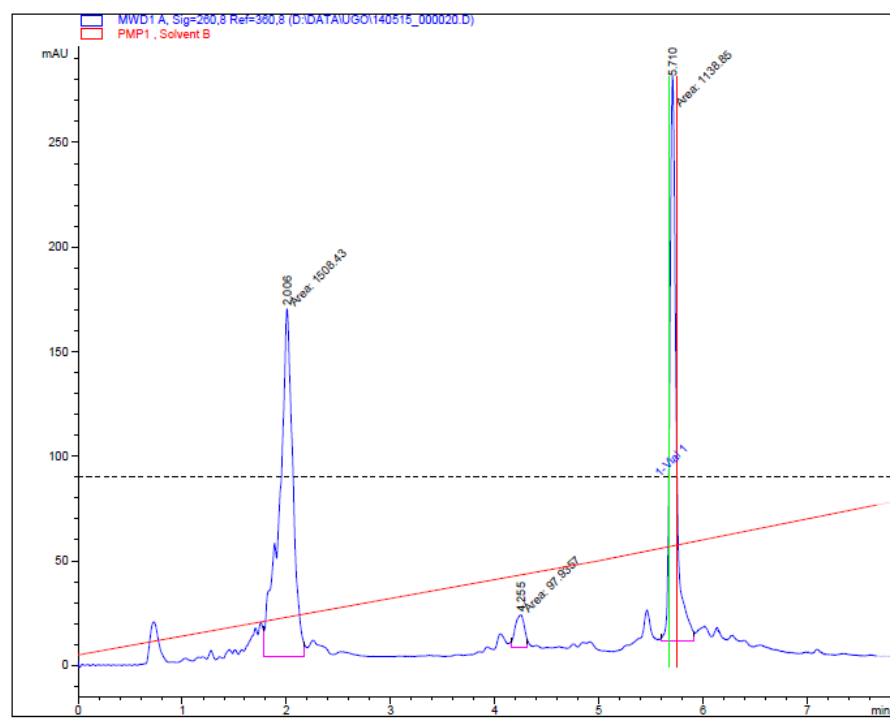

Signa1 1: MWD1 A, Sig $=260,8$ Ref $=360,8$

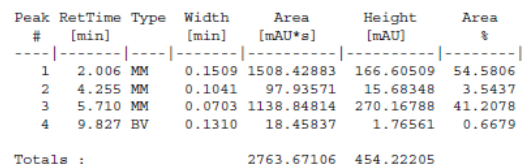

Condition D (THPTA)

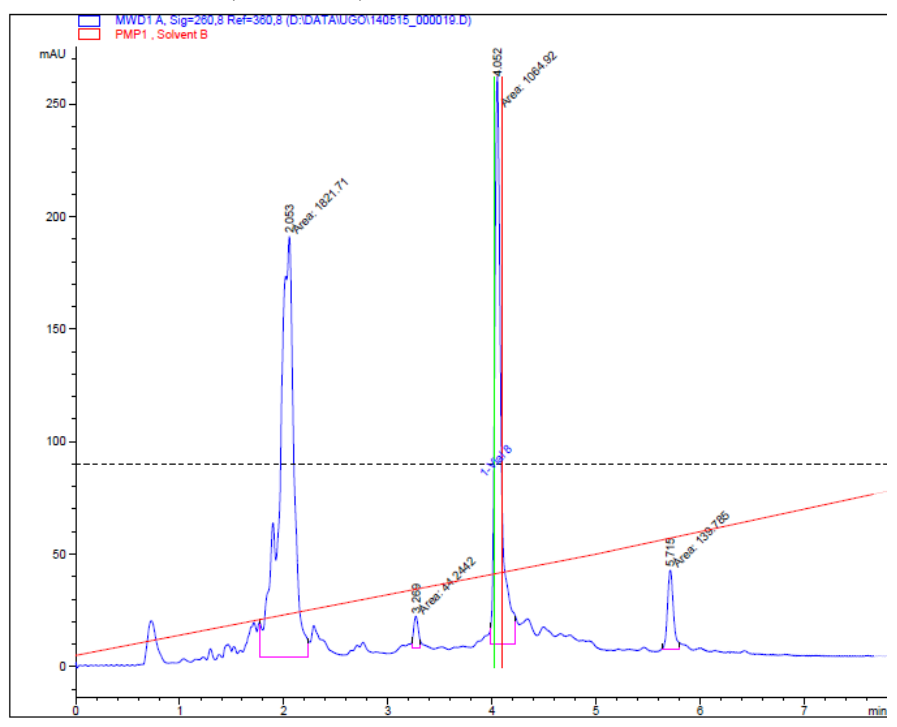

Signa1 1: MND1 A, Sig $=260,8$ Ref $=360,8$

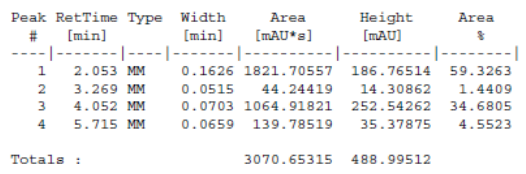

Condition F (TRIS base)

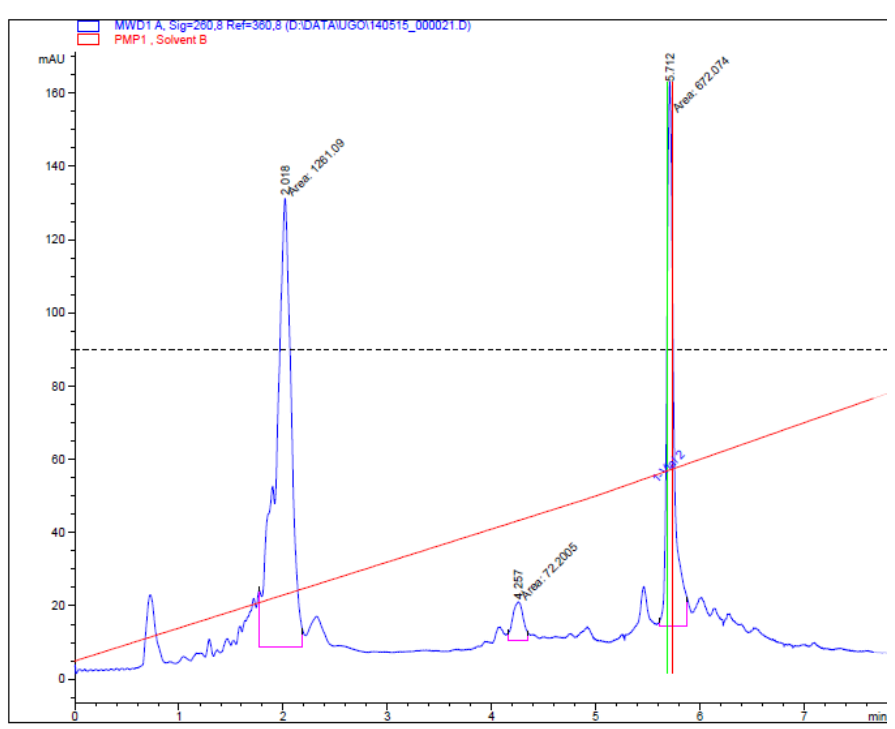

Signa1 1: MND1 A, Sig $=260,8$ Ref $=360,8$

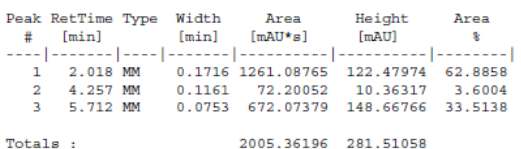




\section{Evaluation of click/reverse-click protocol on pre-miR-21}

\section{Experimental procedure}

Compounds were prepared following the reported procedure in section 2 .

\section{HPLC profiles of crude DMTon $\mathrm{Cy} 3 / \mathrm{N}_{3}$-pre-miR-21}

ORN3-Cy3/N 3 DMTon

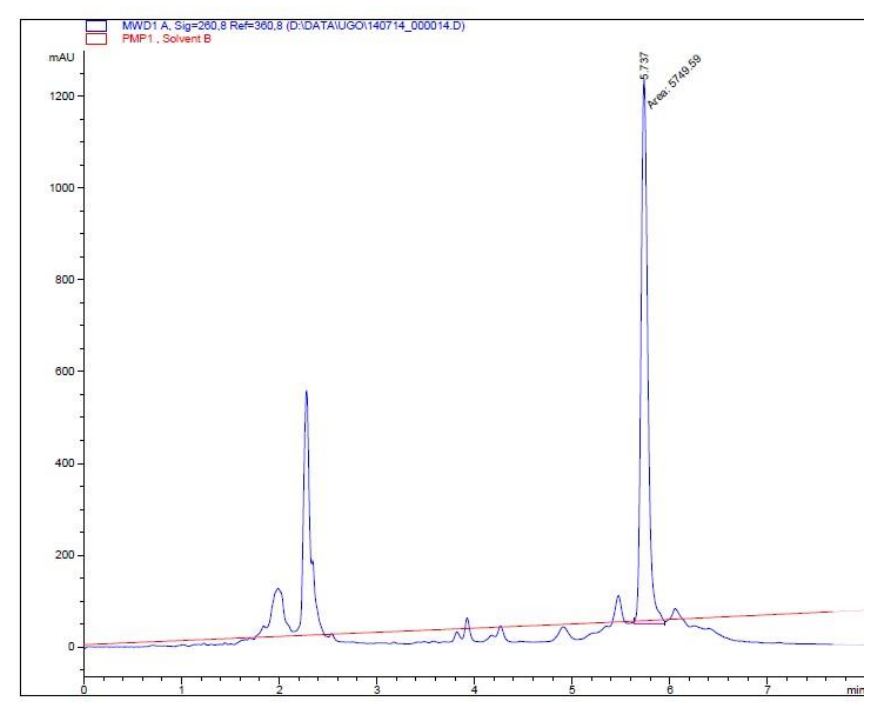

Signal 1: MWD1 A, Sig $=260,8$ Ref $=360,8$

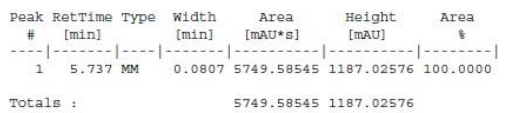

Totals :

5749.585451187 .02576

\section{ORN5-Cy3/ $\mathrm{N}_{3}$ DMTon}

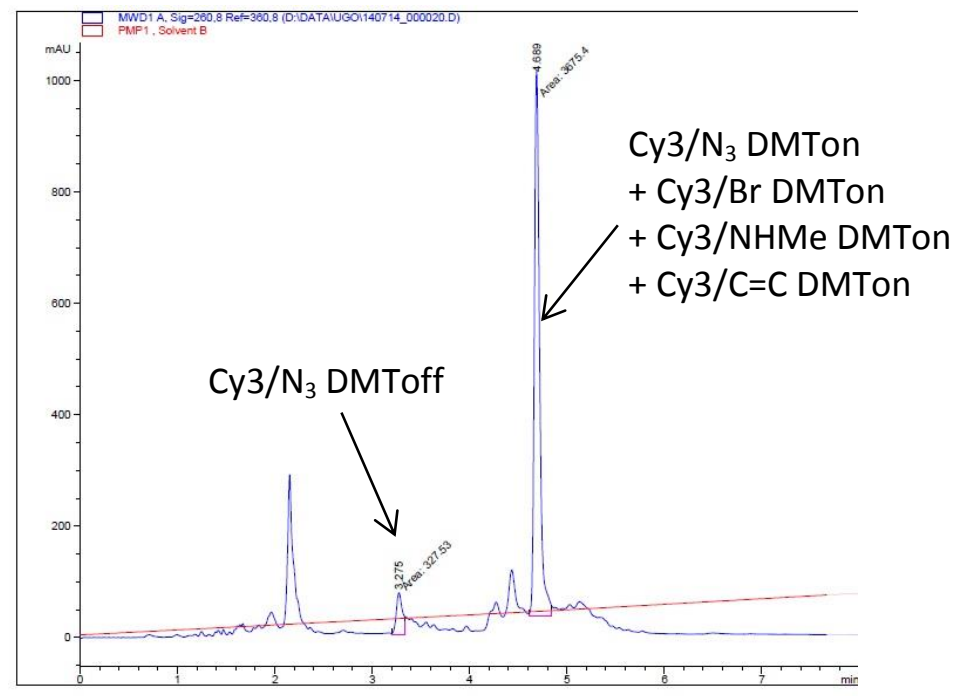

Signal 1: MND1 A, Sig=260, 8 Ref $=360,8$

Peak Retrime Type width
\# [min] $\underset{[m i n]}{\begin{array}{c}\text { Area } \\ \text { [mAU*s] }\end{array}} \begin{gathered}\text { Height } \\ \text { [mAU] }\end{gathered}$ Area

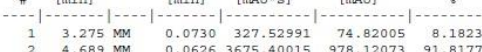

Totals : $\quad 4002.930051052 .94077$
ORN4-Cy3/N 3 DMTon

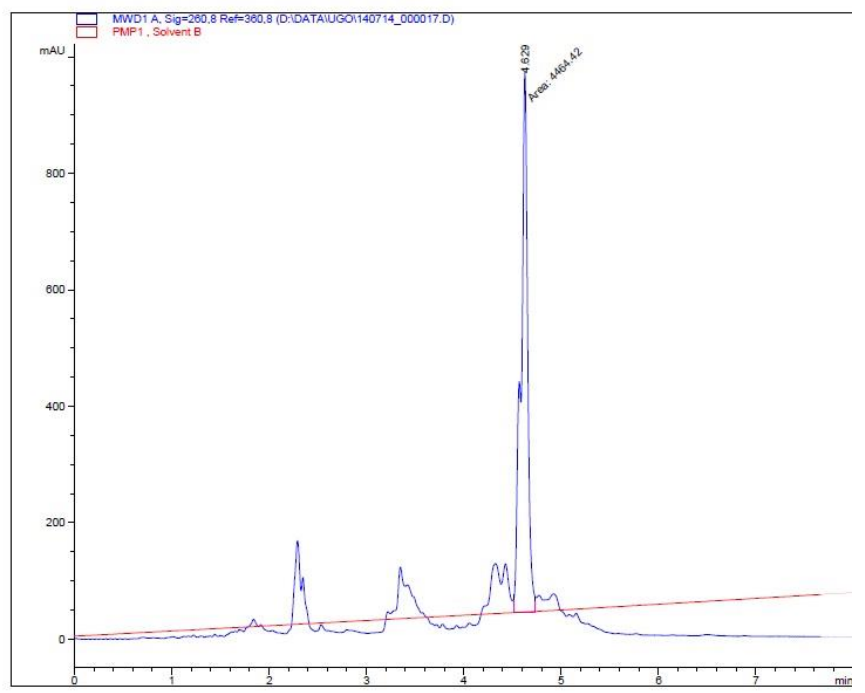

Signal 1: MWD1 A, Sig $=260,8$ Ref $=360,8$

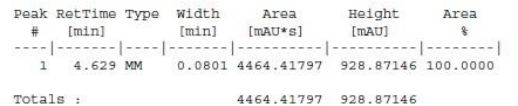

ORN6-Cy3/ $\mathrm{N}_{3}$ DMTon

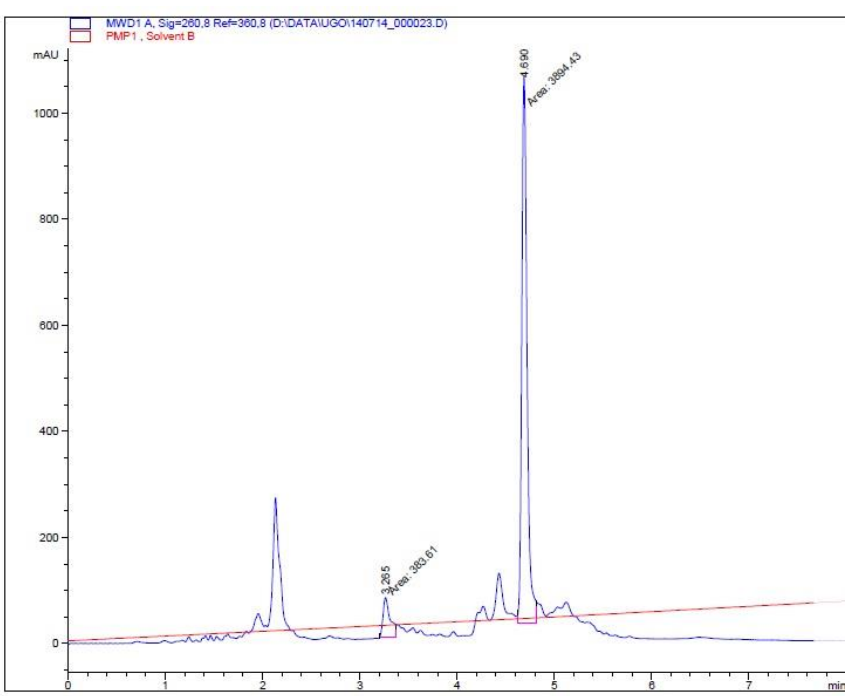

Signal 1: MND1 A, Sig $=260,8$ Ref $=360,8$

Peak RetTime Type width Area Height Area

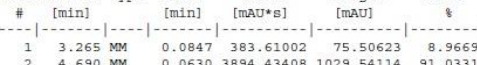

Totals : $\quad 4278.044101105 .04737$ 
HPLC profiles of crude DMToff $\mathrm{Cy} 3 / \mathrm{N}_{3}$-pre-miR-21

\section{ORN3-Cy3/ $\mathrm{N}_{3}$}

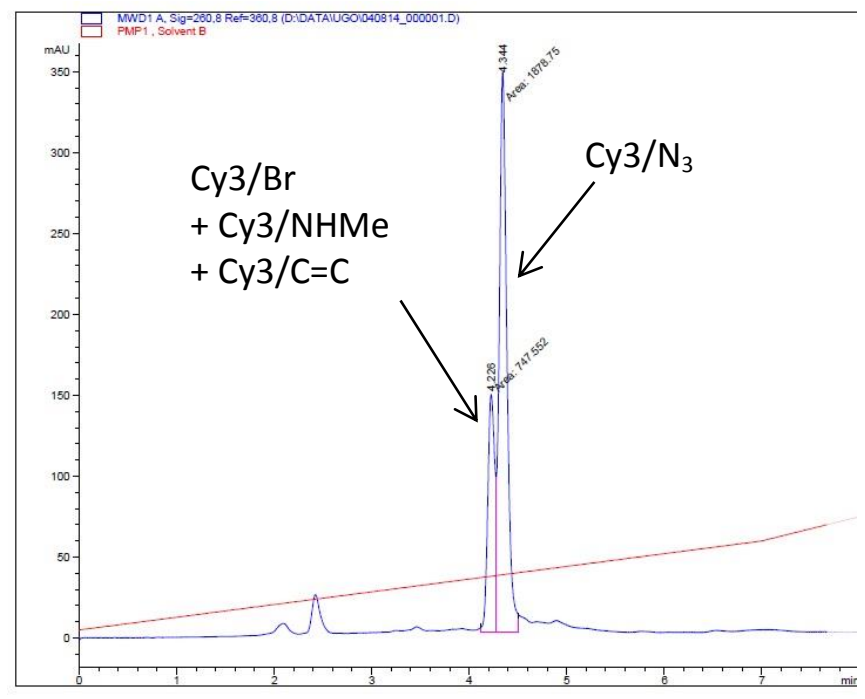

Signal 1: MND1 A, Sig=260, 8 Ref $=360,8$

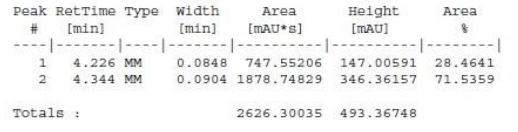

\section{ORN5-Cy3/ $\mathrm{N}_{3}$}

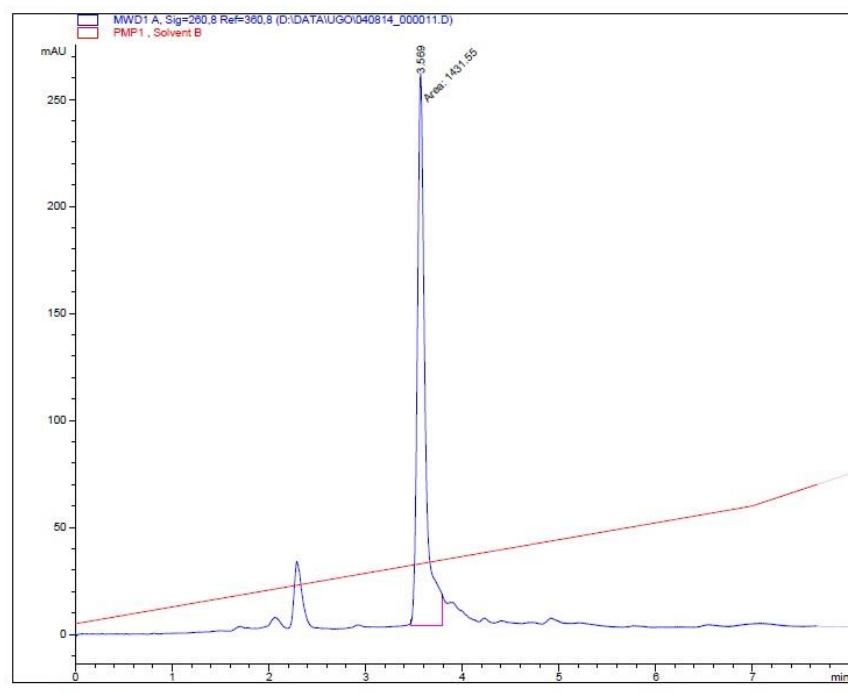

Signa1 1: MWD1 A, Sig $=260,8$ Ref $=360,8$

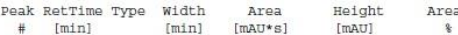

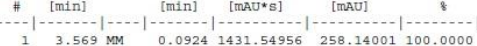

Totals :

$1431.54956 \quad 258.14001$
ORN4-Cy3/ $\mathrm{N}_{3}$

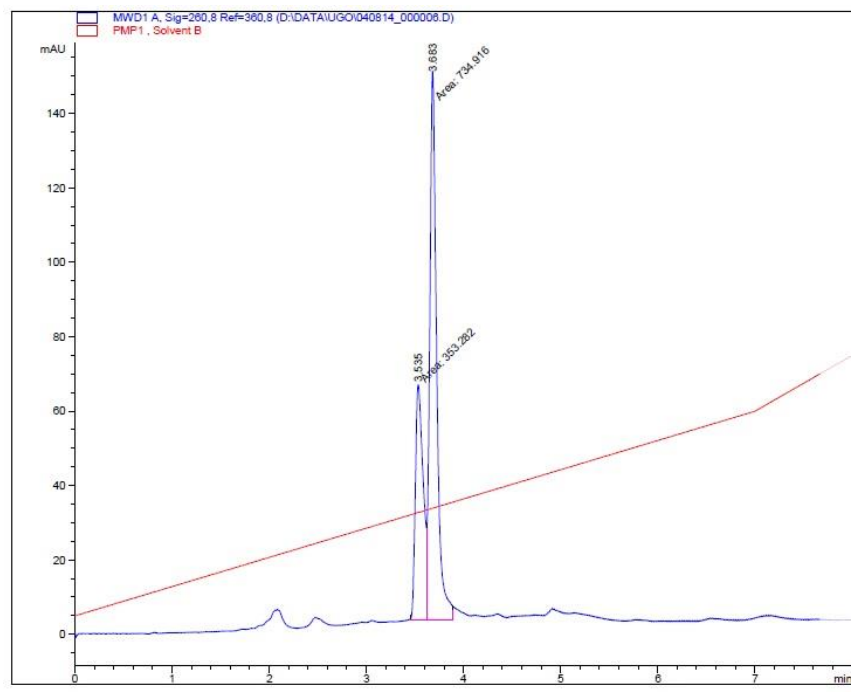

Signal 1: MWD1 A, Sig $=260,8$ Ref $=360,8$

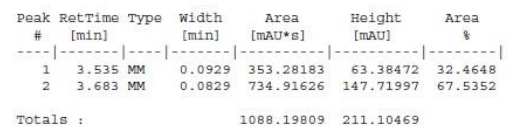

ORN6-Cy3/ $\mathrm{N}_{3}$

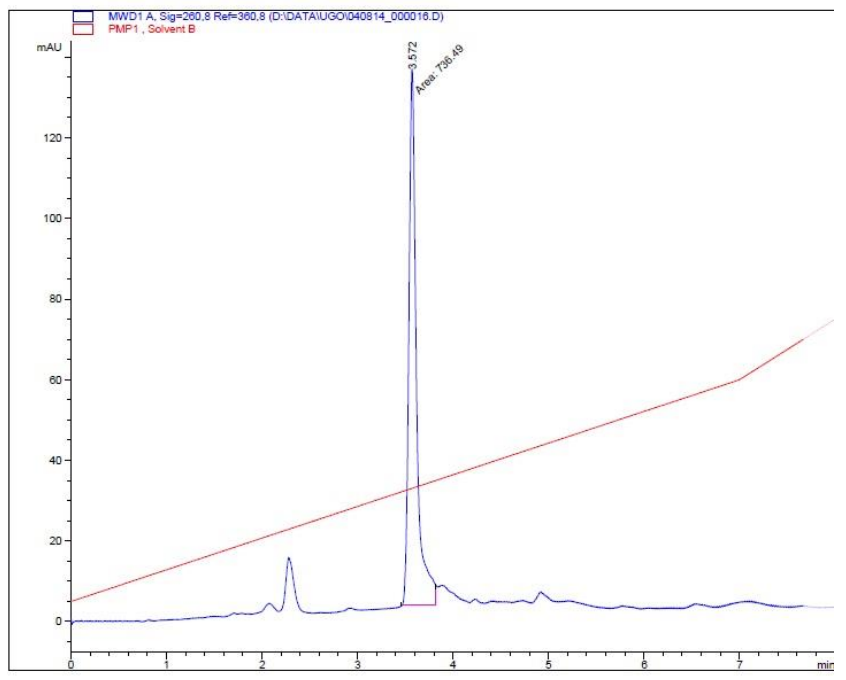

Signal 1: MND1 A, $S 1 g=260,8$ Ref $=360,8$

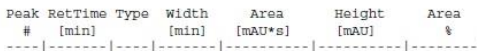

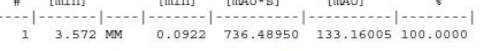

Totals : 
HPLC profiles of crude Cy3/Cy5-pre-miR-21

\section{ORN3-Cy3/Cy5}

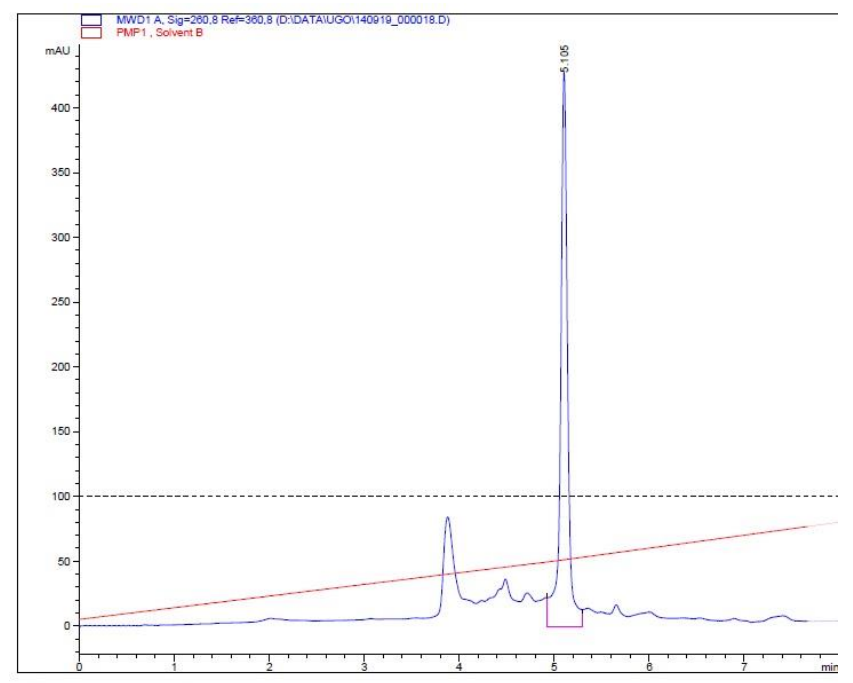

Signa1 1: MND1 A, Sig=260, 8 Ref $=360,8$

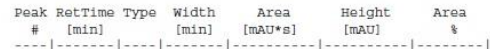

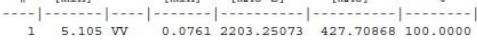

Totals :

\section{ORN5-Cy3/Cy5}

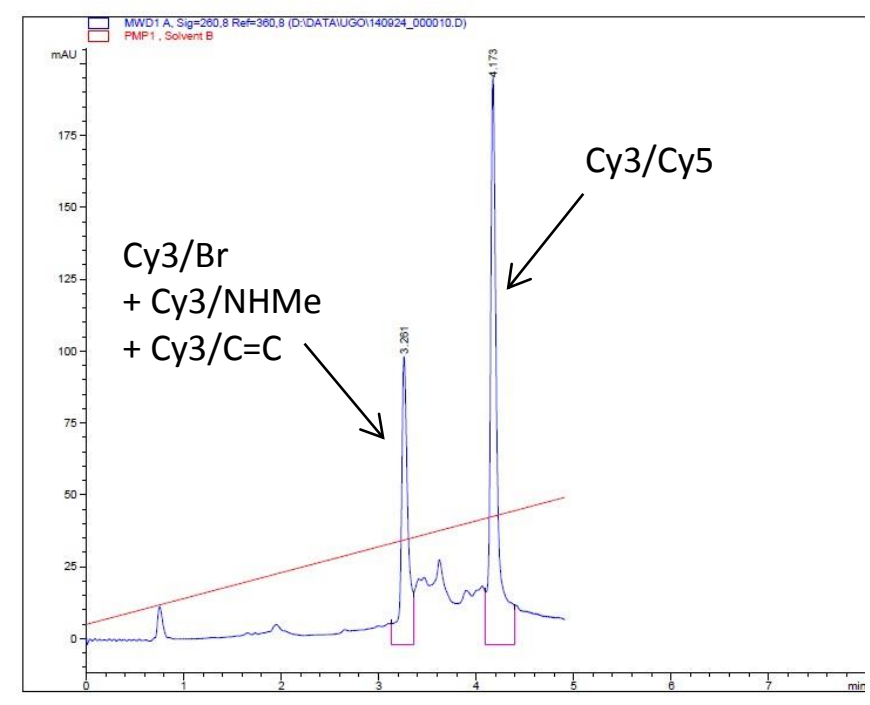

Signal 1: MND1 A, Sig $=260,8$ Ref $=360$, 8

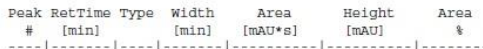

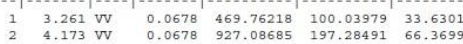

Totals :

$1396.84903 \quad 297.32470$
ORN4-Cy3/Cy5

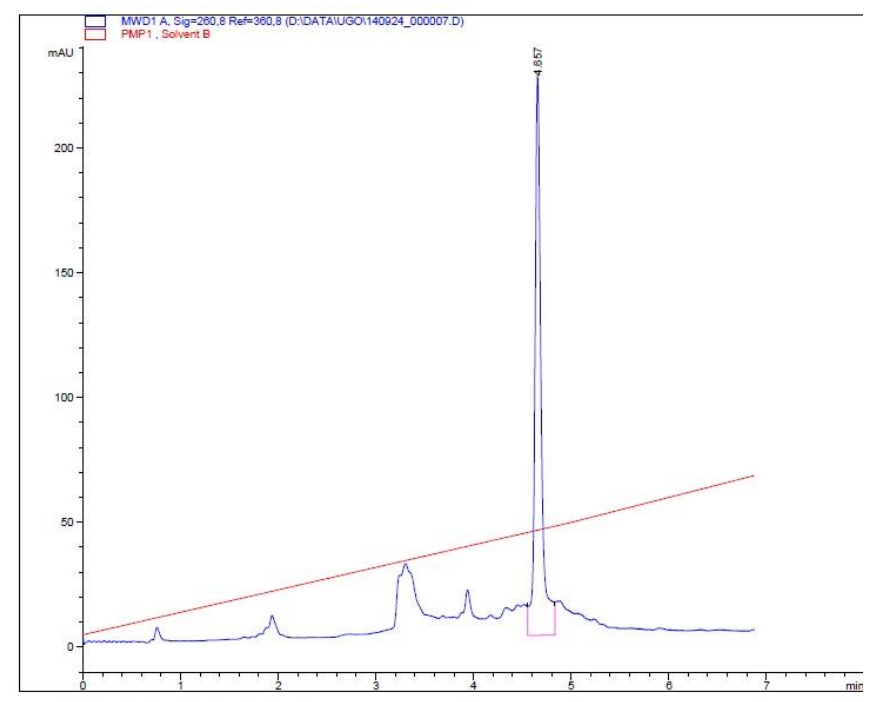

Signa1 1: MWD1 A, Sig $=260,8$ Ref $=360,8$

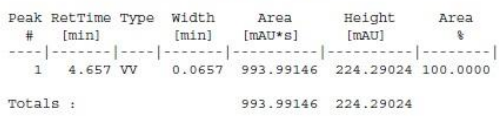

ORN6-Cy3/Cy5

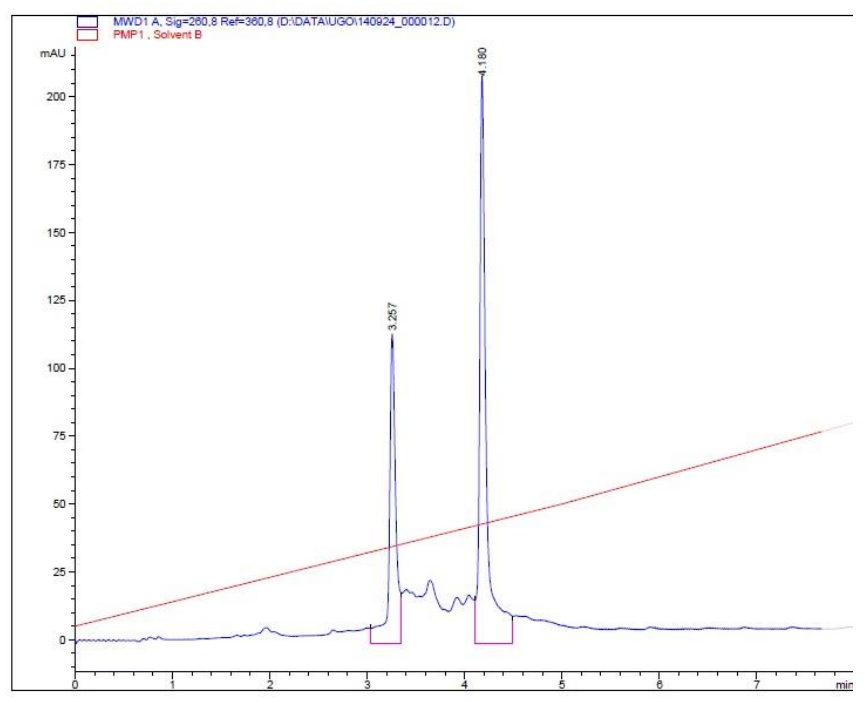

Signal 1: MND1 A, Sig $=260,8$ Ref $=360,8$

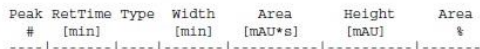

\# [min]

$\begin{array}{rrrrrr}1 & 3.257 \mathrm{VV} & 0.0677 & 533.77521 & 113.91133 & 34.7489 \\ 2 & 4.180 \mathrm{VV} & 0.0690 & 1002.31683 & 208.97122 & 65.2511\end{array}$

Totals : $\quad 1536.09204 \quad 322.88255$ 


\section{Synthesis of reagents}

\subsection{2'-O-methylenetriazolobutylbromide cytidine phosphoramidite}

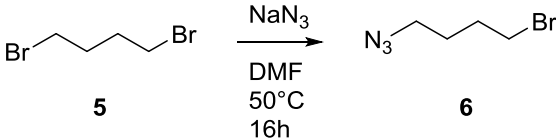

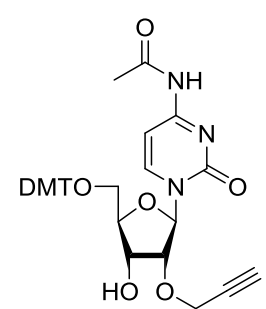

7

$\mathrm{CuSO}_{4} \cdot 5 \mathrm{H}_{2} \mathrm{O}$

$\mathrm{Na}$ ascorbate

$\mathrm{H}_{2} \mathrm{O} / \mathrm{tBuOH} / \mathrm{THF}$

$1 \mathrm{~h}$, r.t.

$80 \%$

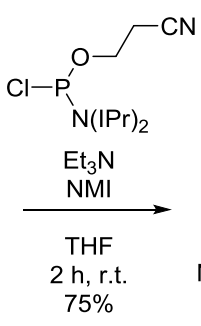

$75 \%$
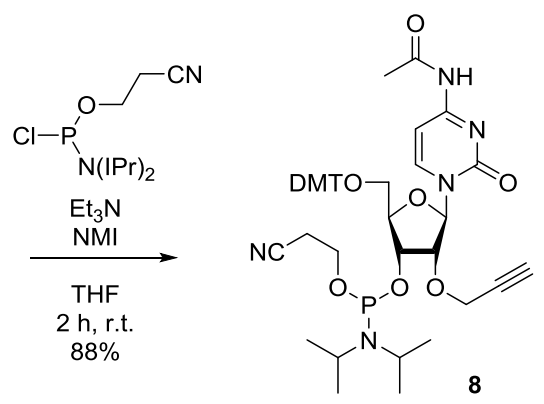

$88 \%$
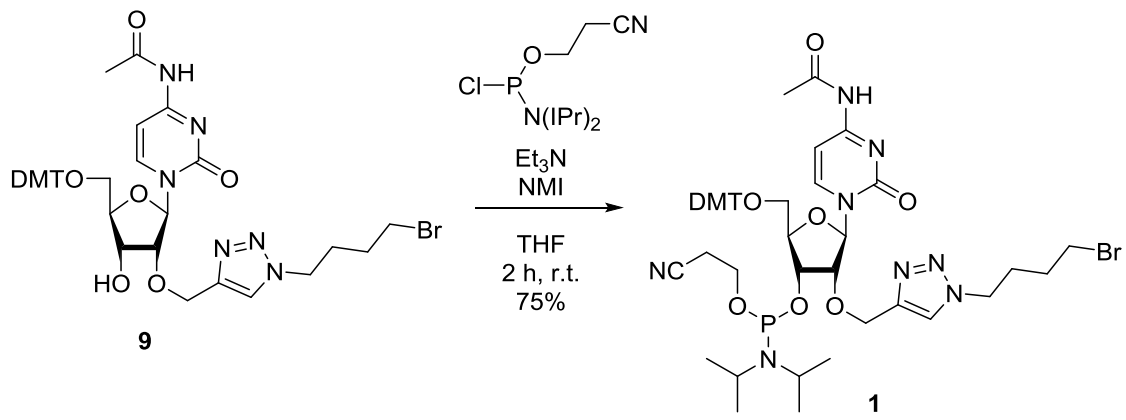

\section{Synthetic procedures}

\section{4-Azido-1-bromobutane 6 (CAS 116114-55-7)}

4-Azido-1-bromobutane was prepared following the protocol of Agnew et al. ${ }^{1}$

To a solution of 1,4-dibromobutane 5 (2 g, $9.26 \mathrm{mmol}, 2$ equiv.) in DMF (15mL) was added sodium azide (300 mg, $4.63 \mathrm{mmol})$. The reaction mixture was stirred at $50{ }^{\circ} \mathrm{C}$ for $16 \mathrm{~h}$ and partitioned between water $(100 \mathrm{~mL})$ and $\mathrm{CH}_{2} \mathrm{Cl}_{2}$ $(200 \mathrm{~mL})$. The organic layer was washed three times with water, once with brine and dried over $\mathrm{Na}_{2} \mathrm{SO}_{4}$. After filtration and evaporation of the volatiles, the crude residue was purified by silica gel column chromatography (up to $10 \% \mathrm{CH}_{2} \mathrm{Cl}_{2}$ in hexanes, TLC revelation with $\left.\mathrm{KMnO}_{4}\right)$ to give compound $6(680 \mathrm{mg}, 3.84 \mathrm{mmol}, 83 \%$ yield) as a clear oil.

\footnotetext{
${ }^{1}$ Agnew, H.D., Rohde, R.D.; Millward, S.W.; Nag, A.; Yeo, W.-S.; Hein, J.E.; Pitram, S.M.; Tariq, A.; Burns, V.M.; Krom, R.J.; Fokin, V.V.; Sharpless, K.B.; Heath, J.R. Angew. Chem. Int. Ed. 2009, 48, 4944-4948
} 


\section{2'-O-propargyl-5'-dimethoxytrityl- $N^{4}$-acetyl-cytidine 7}

For a detailed synthesis in three steps starting from cytidine, see our previous report. ${ }^{2}$

\section{2'-O-propargyl-5'-dimethoxytrityl- $N^{4}$-acetyl-cytidine phosphoramidite 8}

For a detailed synthesis in three steps starting from cytidine, see our previous report. ${ }^{2}$

\section{2'-O-methylenetriazolobutylbormide-5'-dimethoxytrityl- $N^{4}$-acetyl-cytidine 9}

To a solution of compound $7(1.5 \mathrm{~g}, 2.4 \mathrm{mmol})$ dissolved in a mixture of water $(5 \mathrm{~mL})$, tBuOH $(5 \mathrm{~mL})$, and THF (5 $\mathrm{mL}$ ) at room temperature were successively added azidobutylbromide 6 ( $850 \mathrm{mg}, 4.8 \mathrm{mmol}, 2$ equiv.), $\mathrm{CuSO}_{4} .5 \mathrm{H}_{2} \mathrm{O}$ (60 mg, $0.24 \mathrm{mmol}, 0.1$ equiv.) and sodium ascorbate $(95 \mathrm{mg}, 0.48 \mathrm{mmol}, 0.2$ equiv.). After $1 \mathrm{~h}$ stirring at room temperature, the reaction mixture was partitioned between EtOAc $(250 \mathrm{~mL})$ and water $(250 \mathrm{~mL})$. The organic phase was washed twice with water, once with brine and dried over $\mathrm{Na}_{2} \mathrm{SO}_{4}$. After filtration and evaporation of the volatiles, the crude residue was purified by silica gel column chromatography (up to 5\% $\mathrm{MeOH}$ in EtOAc to give compound 9 (1.544 g, $1.92 \mathrm{mmol}, 80 \%$ yield) as a white amorphous solid. 1H-NMR (400 MHz, $\left.\mathrm{CDCl}_{3}\right) \delta=9.57(\mathrm{~s}, 1 \mathrm{H}), 8.45(\mathrm{~d}, \mathrm{~J}$ $=7.3 \mathrm{~Hz}, 1 \mathrm{H}), 7.57(\mathrm{~s}, 1 \mathrm{H}), 7.32(\mathrm{~d}, \mathrm{~J}=7.2 \mathrm{~Hz}, 2 \mathrm{H}), 7.34-7.14(\mathrm{~m}, 8 \mathrm{H}), 7.04(\mathrm{br}, 1 \mathrm{H}), 6.76(\mathrm{dd}, \mathrm{J}=8.9,1.6 \mathrm{~Hz}, 4 \mathrm{H})$, $5.93(\mathrm{~s}, 1 \mathrm{H}), 5.05(\mathrm{~d}, \mathrm{~J}=12.7 \mathrm{~Hz}, 1 \mathrm{H}), 4.97(\mathrm{~d}, \mathrm{~J}=12.7 \mathrm{~Hz}, 1 \mathrm{H}), 4.39(\mathrm{br}, 1 \mathrm{H}), 4.25(\mathrm{t}, \mathrm{J}=6.8 \mathrm{~Hz}, 2 \mathrm{H}), 4.07(\mathrm{~d}, \mathrm{~J}=$ $9.1 \mathrm{~Hz}, 1 \mathrm{H}), 4.00(\mathrm{~d}, \mathrm{~J}=4.6 \mathrm{~Hz}, 1 \mathrm{H}), 3.72(\mathrm{~s}, 3 \mathrm{H}), 3.71(\mathrm{~s}, 3 \mathrm{H}), 3.48(\mathrm{~s}, 2 \mathrm{H}), 3.30$ (t, J = 6.4 Hz, 2H), 2.16 (s, 3H), 1.99-1.91 (m, 2H), 1.78-1.71 (m, 2H). 13C-NMR (100 MHz, $\left.\mathrm{CDCl}_{3}\right) \delta=170.30,162.67,158.59,158.57,155.14$, $144.81,144.26,143.99,135.46,135.17,130.03,128.10,127.94,127.03,123.25,113.22,96.57,89.13,86.88,83.00$, 81.52,67.69, 63.25, 60.79, 55.16, 49.23, 32.44, 29.19, 28.56, 24.85. ESI-MS: negative mode 801.3 ([M-H]'). Calc.: 802.2.

\section{2'-O-methylenetriazolobutylbormide-5'-dimethoxytrityl- $N^{4}$-acetyl-cytidine phosphoramidite 1}

To a solution of 2'-O-methylenetriazolobutylbormide-5'-dimethoxytrityl- ${ }^{4}$-acetyl-cytidine 9 (1.15g, 1.43 mmol, 1 equiv.) in THF $(10 \mathrm{~mL})$ at $0{ }^{\circ} \mathrm{C}$ were added $\mathrm{Et}_{3} \mathrm{~N}(0.96 \mathrm{~mL}, 7.16 \mathrm{mmol}, 5$ equiv. $)$, 2-Cyanoethyl $\mathrm{N}, \mathrm{N}-$ diisopropylchlorophosphoramidite $\left(1.01 \mathrm{~g}, 4.29 \mathrm{mmol}, 3\right.$ equiv.). After $2 \mathrm{~h}$ stirring at $0{ }^{\circ} \mathrm{C}$, the reaction mixture was partitioned between a $5 \% \mathrm{NaHCO}_{3}$ aqueous solution $(100 \mathrm{~mL})$ and EtOAc $(100 \mathrm{~mL})$. The aqueous layer was extracted three times by EtOAc $(3 \times 30 \mathrm{~mL})$. The combined organic layer was washed twice with water $(2 \times 20 \mathrm{~mL})$ and once with brine $(20 \mathrm{~mL})$, dried over sodium sulfate, filtered and evaporated to dryness. The residue was purified by flash column chromatography with a gradient up to $2 \% \mathrm{MeOH}$ in $\mathrm{EtOAc}\left(0.5 \% \mathrm{Et}_{3} \mathrm{~N}\right)$ to afford phosphoramidite 1 (1.07 g, $1.07 \mathrm{mmol}, 75 \%$ yield) as a white foam. 31P-NMR (66 MHz, CDCl3) $\delta=150.39,149.87$. ESI-HRMS calculated for C48 H60 Br N8 Na O9 P positive mode ([M+Na]+) 1025.3291. Calc.:1025.3296.

\footnotetext{
${ }^{2}$ Pradère, U.; Brunschweiger, A.; Gebert, L.F.R.; Lucic, M.; Roos, M.; Hall, J. Angew. Chem. Int. Ed. 2013, 52, 12028-12032
} 


\section{NMR Spectras}

\section{2'-O-methylenetriazolobutylbormide-5'-dimethoxytrityl- $N^{4}$-acetyl-cytidine 9}

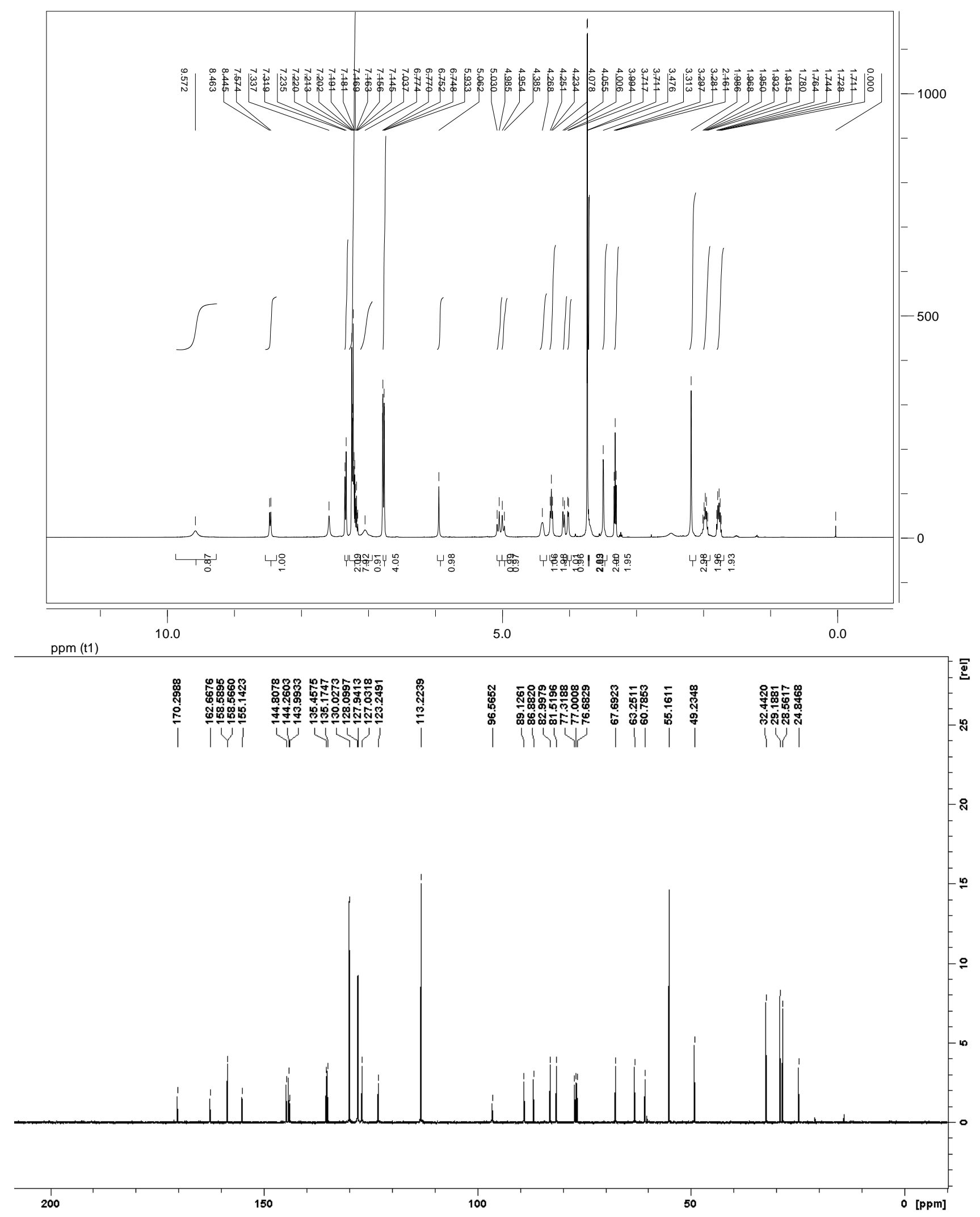


2'-O-methylenetriazolobutylbormide-5' -dimethoxytrityl- $N^{4}$-acetyl-cytidine phosphoramidite 1

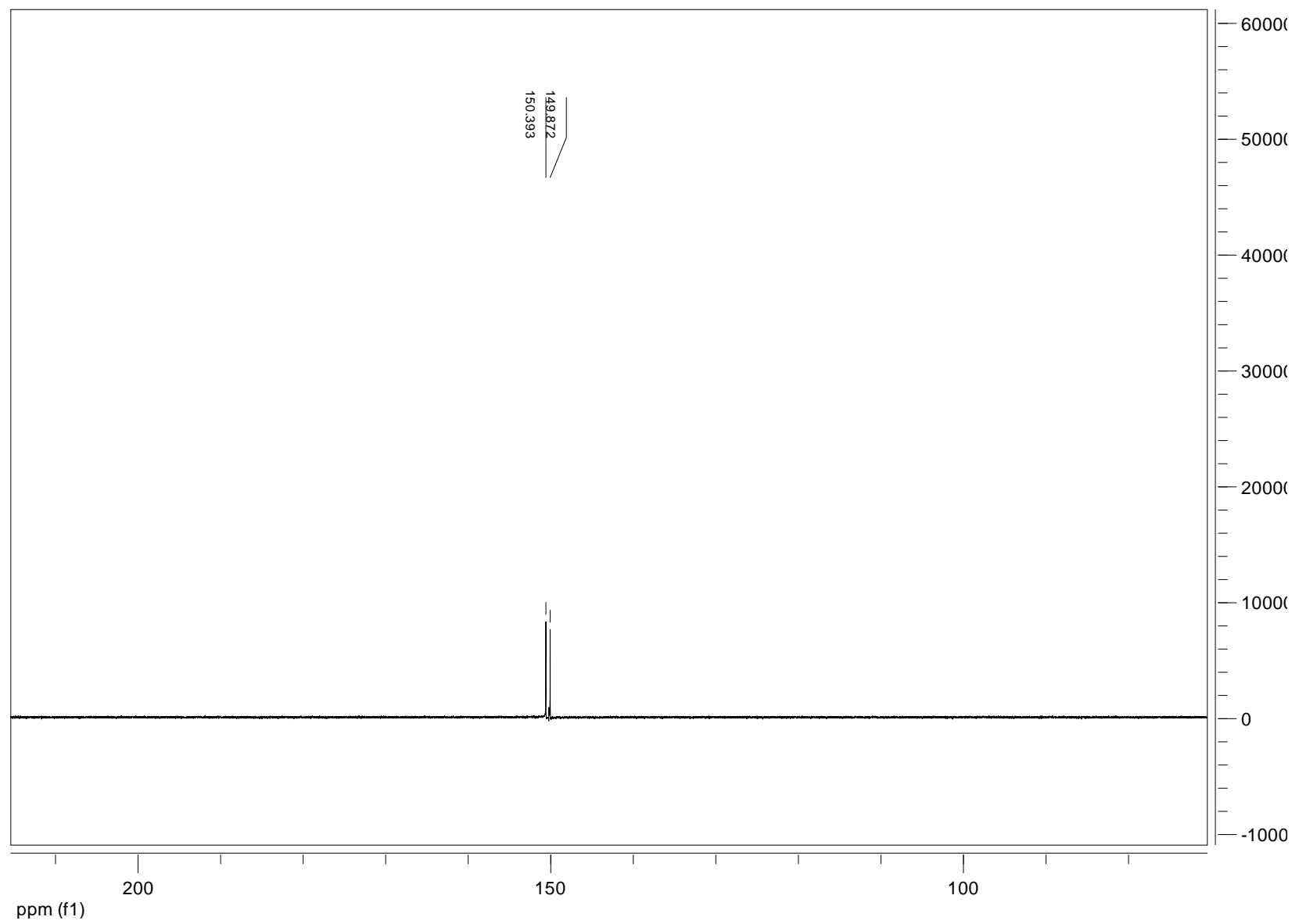




\subsection{Cy3 alkyne}

\section{Synthetic procedures}
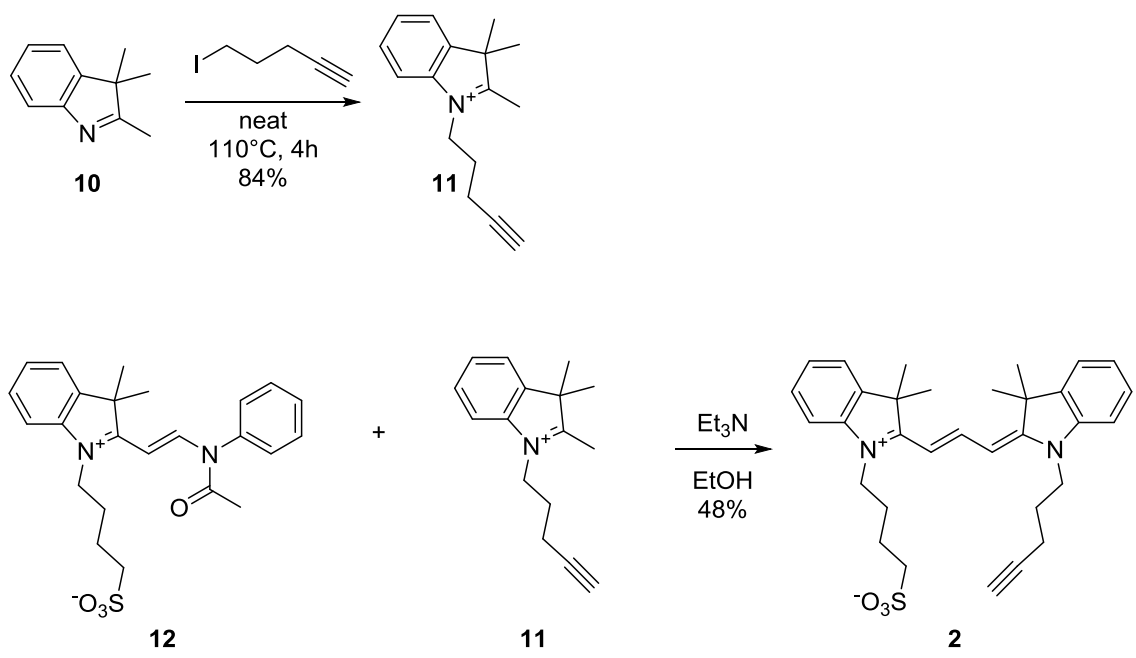

\section{5-iodopent-1-yne (CAS 2468-55-5)}

5-iodopent-1-yne was prepared following a modified procedure of Barber et al. ${ }^{3}$

\section{2,3,3-Trimethyl-1-(pent-4-yne)-3H-indolium 11 (CAS 1354932-44-7) ${ }^{4}$}

To a $5 \mathrm{~mL}$ round bottom flask were added 2,3,3-trimethylindolenine $\mathbf{1 0}$ (372mg, $2.34 \mathrm{mmol}, 1$ equiv.) and 5iodopent-1-yne (500 mg, $2.58 \mathrm{mmol}, 1.1$ equiv.). The reaction mixture was stirred at $110{ }^{\circ} \mathrm{C}$ for $4 \mathrm{~h}$, cooled to room temperature and diluted with $\mathrm{CH}_{2} \mathrm{Cl}_{2}(3 \mathrm{~mL})$ and $\mathrm{MeOH}(0.5 \mathrm{~mL})$. Precipitation in $\mathrm{Et}_{2} \mathrm{O}(75 \mathrm{~mL})$, filtration and washing with $\mathrm{Et}_{2} \mathrm{O}$ afforded compound 11 (440 mg, $\left.1.76 \mathrm{mmol}, 84 \%\right)$ as a purple solid.

\section{2-[2-(Acetylphenylamino)ethenyl]-3,3-dimethyl-1-(4-sulfobutyl)-3H-indolium 12}

For a detailed synthesis of 2-[2-(Acetylphenylamino)ethenyl]-3,3-dimethyl-1-(4-sulfobutyl)-3H-indolium 12 in three steps starting from 2,3,3-trimethylindolenine 10, see our previous report. ${ }^{2}$

\section{2-[3-[1,3-Dihydro-3,3-dimethyl-1-(4-sulfobutyl)-2H-indol-2-ylidene]-1-propen-1-yl]-3,3-dimethyl-1-(4- azidobutyl)-3H-Indolium 2 (Cy3 alkyne)}

To solution of hemicyanine 12 (454 mg, $1.03 \mathrm{mmol}, 1$ equiv.) and compound 11 (225 mg, $1.03 \mathrm{mmol}, 1$ equiv.) in EtOH $(20 \mathrm{~mL})$ was added triethylamine $\left(420 \mu \mathrm{L}, 3.09 \mathrm{mmol}, 3\right.$ equiv.). The reaction mixture was heated to $80{ }^{\circ} \mathrm{C}$ for $30 \mathrm{~min}$, cooled to room temperature and evaporated to dryness. The residue was partitioned between water $(50 \mathrm{~mL})$

\footnotetext{
${ }^{3}$ Barber, D.M.; Sanganee, H.J.; Dixon D.J. Org. Lett. 2012, 14, 5290-5293

${ }^{4}$ Gerowska, M.; Hall, L.; Richardson, J.; Shelbourne, M.; Brown, T. Tetrahedron 2012, 68, 857-864
} 
and $\mathrm{CH}_{2} \mathrm{Cl}_{2}(50 \mathrm{~mL})$. The organic phase was washed twice with water $(2 \mathrm{x} 25 \mathrm{~mL})$, dried over $\mathrm{Na}_{2} \mathrm{SO}_{4}$ and evaporated to dryness. The crude residue was purified by silica gel column chromatography (gradient up to $5 \% \mathrm{MeOH}$ in $\mathrm{CH}_{2} \mathrm{Cl}_{2}$ ) to afford Cy3 alkyne 2 (263 mg, $0.50 \mathrm{mmol}, 48 \%$ yield) as a dark purple solid. ${ }^{1} \mathrm{H}-\mathrm{NMR}\left(400 \mathrm{MHz}, \mathrm{CDCl}_{3}\right)$ $\delta=8.38(\mathrm{t}, \mathrm{J}=13.4 \mathrm{~Hz}, 1 \mathrm{H}), 7.45(\mathrm{~d}, \mathrm{~J}=13.5 \mathrm{~Hz}, 1 \mathrm{H}), 7.43-7.32(\mathrm{~m}, 4 \mathrm{H}), 7.24-7.13(\mathrm{~m}, 5 \mathrm{H}), 4.43(\mathrm{t}, \mathrm{J}=7.4 \mathrm{~Hz}, 2 \mathrm{H})$, $4.27(\mathrm{t}, \mathrm{J}=8.0 \mathrm{~Hz}, 2 \mathrm{H}), 3.06(\mathrm{t}, \mathrm{J}=7.7 \mathrm{~Hz}, 2 \mathrm{H}), 2.56(\mathrm{td}, \mathrm{J}=6.5,2.5 \mathrm{~Hz}, 2 \mathrm{H}), 2.27-2.19(\mathrm{~m}, 2 \mathrm{H}), 2.15-2.08(\mathrm{~m}, 3 \mathrm{H})$, 2.04-1.96 (m, 2H), 1.70 (s, 6H), 1.69 (s, 6H). ${ }^{13} \mathrm{C}-\mathrm{NMR}\left(100 \mathrm{MHz}, \mathrm{CDCl}_{3}\right) \delta=173.85,173.33,151.16,142.49,142.10$, 140.76, 140.53, 128.89, 128.74, 125.09, 124.78, 121.88, 111.13, 110.81, 105.80, 104.80, 84.14, 69.41, 51.08, 48.79, $48.65,44.65,43.13,29.65,28.18,28.07,26.52,26.14,22.94,15.86$. ESI-HRMS calculated for C32 H39 N2 O3 S positive mode ([M]+) 531.2671. Calc.: 531.2676. 
NMR Spectras of Cy3 alkyne 2

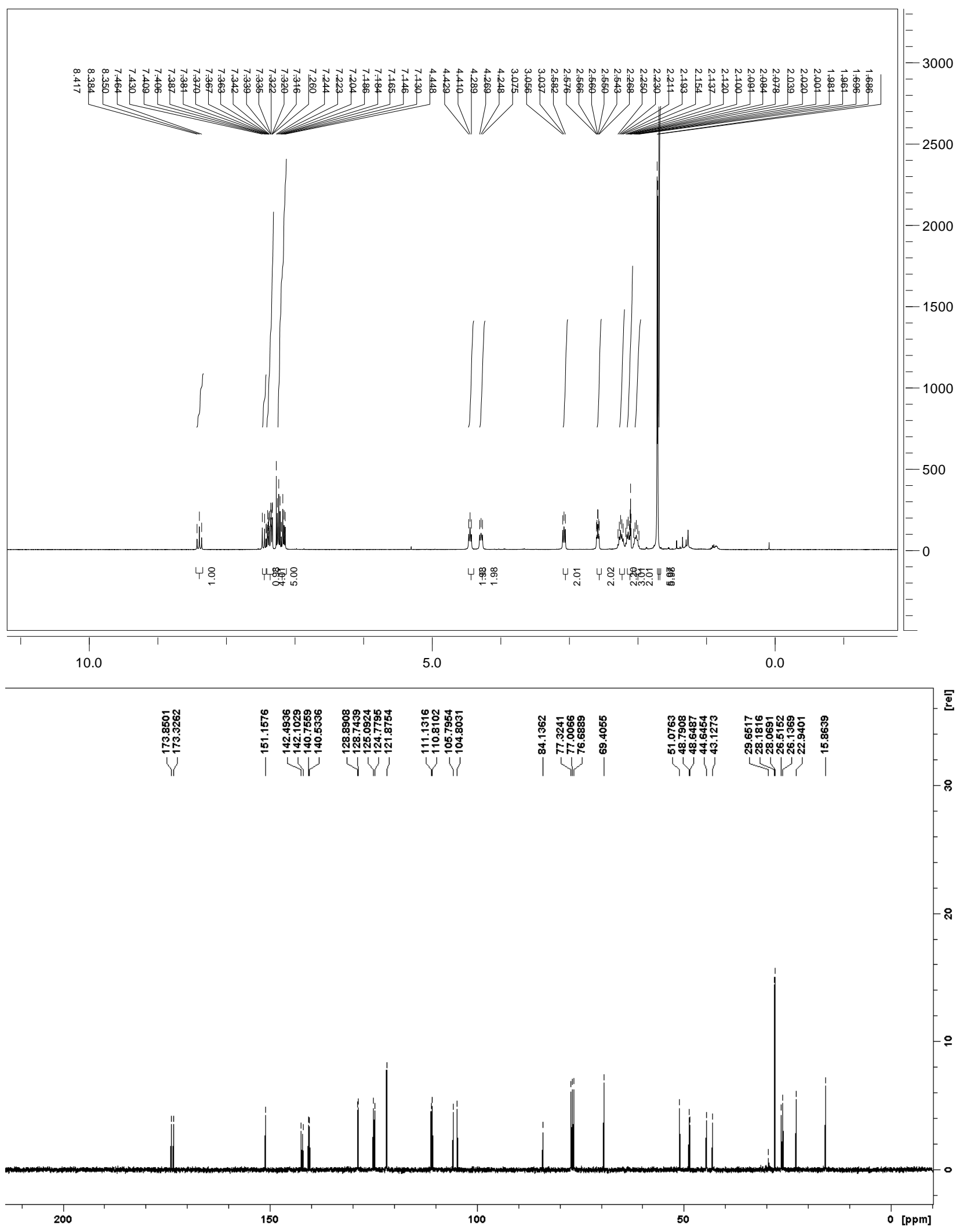




\subsection{Cy5 alkyne}

\section{Synthetic procedures}
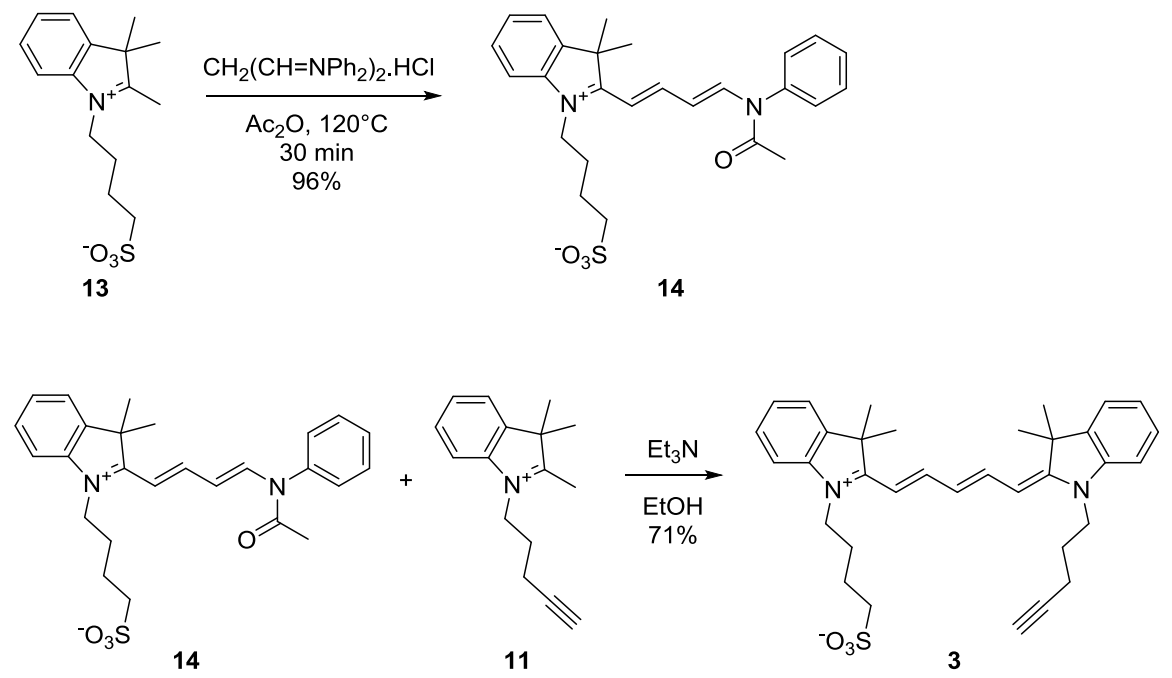

\section{2-[4-(acetylphenylamino)-1,3-butadien-1-yl]-3,3-dimethyl-1-(4-sulfobutyl)-3H-Indolium}

\section{5-11-3)}

Compound 13 was prepared following the procedure of Kvach et al. ${ }^{5}$

To a stirred solution of compound 13 (1.588 g, $5.38 \mathrm{mmol}, 1$ equiv.) in acetic anhydride (20 mL) was added malonaldehyde bis(phenylimine) hydrochloride (1.805 g, $7.0 \mathrm{mmol}, 1.3$ equiv.). After $30 \mathrm{~min}$ stirring at $120^{\circ} \mathrm{C}$, the reaction mixture was evaporated to dryness and dissolved in dichloromethane $(2 \mathrm{~mL})$. Ether $(50 \mathrm{~mL})$ was added and the resulting gum was filtered. The gum was dissolved in dichloromethane $(2 \mathrm{~mL})$ and precipitated by addition of ether (100 mL) affording hemicyanine $14(675 \mathrm{mg}, 1.52 \mathrm{mmol}, 86 \%$ yield $)$ as a light brown solid.

\section{2-[5-[1,3-dihydro-1-(4-sulfobutyl)-3,3-dimethyl-2H-indol-2-ylidene]-1,3-pentadien-1-yl]-3,3-dimethyl- 1-(4-pentenyl)-3H-Indolium 3 (Cy5 alkyne)}

To solution of hemicyanine 14 ( $1 \mathrm{~g}, 2.14 \mathrm{mmol}, 1$ equiv.) and 11 (549 mg, 2.14 mmol, 1 equiv.) in EtOH (20 mL) was added triethylamine ( $864 \mu \mathrm{L}, 6.42 \mathrm{mmol}, 3$ equiv.). The reaction mixture was heated to $80{ }^{\circ} \mathrm{C}$ for $30 \mathrm{~min}$, cooled to room temperature and evaporated to dryness. The residue was partitioned between water (200 mL) and $\mathrm{CH}_{2} \mathrm{Cl}_{2}$ $(200 \mathrm{~mL})$. The organic phase was washed twice with water $(2 \times 50 \mathrm{~mL})$, dried over $\mathrm{Na}_{2} \mathrm{SO}_{4}$ and evaporated to dryness. The crude residue was purified by silica gel column chromatography (gradient up to $8 \% \mathrm{MeOH}$ in $\mathrm{CH}_{2} \mathrm{Cl}_{2}$ ) to afford Cy5 alkyne 3 (850 mg, $1.53 \mathrm{mmol}, 71 \%$ yield) as a dark blue solid. ${ }^{1} \mathrm{H}-\mathrm{NMR}\left(400 \mathrm{MHz}, \mathrm{CD}_{3} \mathrm{OD}\right) \delta=8.21(\mathrm{dt}, \mathrm{J}=$

5 Kvach, M.V.; Gontarev, S.V.; Prokhorenko, I.A.; Stepanova, I.A.; Shmanai, V.V.; Korshun, V.A. Russ. Chem. Bull. 2006, 55, 159-163. 
13.0, 7.5 Hz, 2H), $7.48(\mathrm{dd}, \mathrm{J}=7.0,5.0 \mathrm{~Hz}, 2 \mathrm{H}), 7.43-7.22(\mathrm{~m}, 6 \mathrm{H}), 6.64(\mathrm{t}, \mathrm{J}=12.4 \mathrm{~Hz}, 1 \mathrm{H}), 6.41(\mathrm{~d}, \mathrm{~J}=13.8 \mathrm{~Hz}$, $1 \mathrm{H}), 6.34(\mathrm{~d}, \mathrm{~J}=13.6 \mathrm{~Hz}, 1 \mathrm{H}), 4.21-4.14(\mathrm{~m}, 4 \mathrm{H}), 2.90(\mathrm{t}, \mathrm{J}=6.8 \mathrm{~Hz}, 2 \mathrm{H}), 2.54(\mathrm{t}, \mathrm{J}=2.6 \mathrm{~Hz}, 1 \mathrm{H}), 2.37(\mathrm{dt}, \mathrm{J}=6.6$, $2.6 \mathrm{~Hz}, 2 \mathrm{H}), 1.98$ (br, 6H), 1.71 (s, 12H). ${ }^{13} \mathrm{C}-\mathrm{NMR}\left(100 \mathrm{MHz}, \mathrm{CDCl}_{3}\right) \delta=175.27,174.16,155.93,155.16,143.60$, $143.42,142.77,142.48,129.83,129.68,127.05,126.44,126.00,123.39,123.36,112.34,111.66,105.10,104.02$, 83.79, 71.48, 51.68, 50.69, 50.38, 44.91, 43.60, 28.01, 27.89, 27.21, 23.50, 16.54. ESI-HRMS calculated for C34 H41 N2 O3 S positive mode ([M]+) 557.2836. Calc.: 557.2832. 


\section{NMR Spectras of Cy5 alkyne 3}

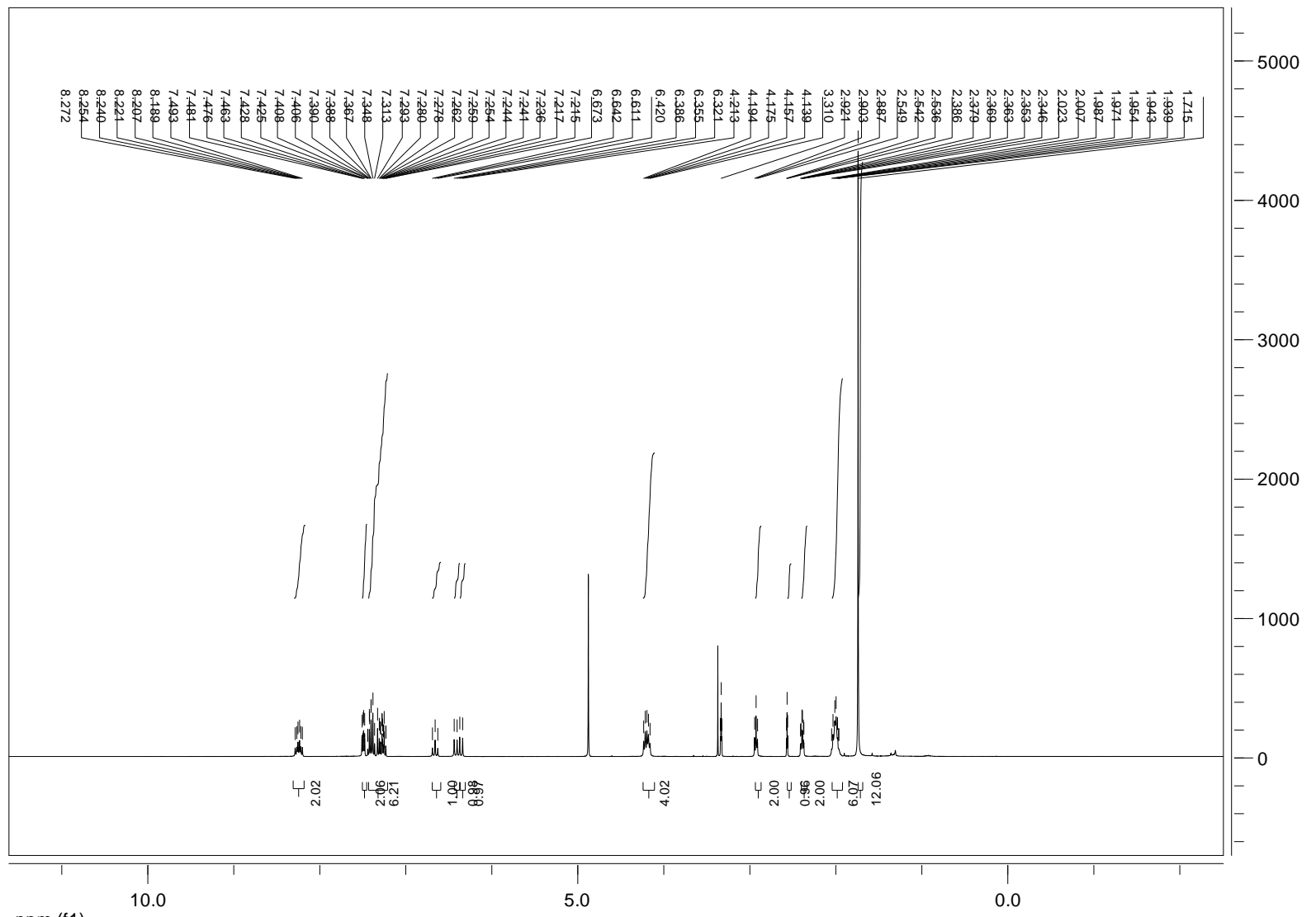

ppm (f1)
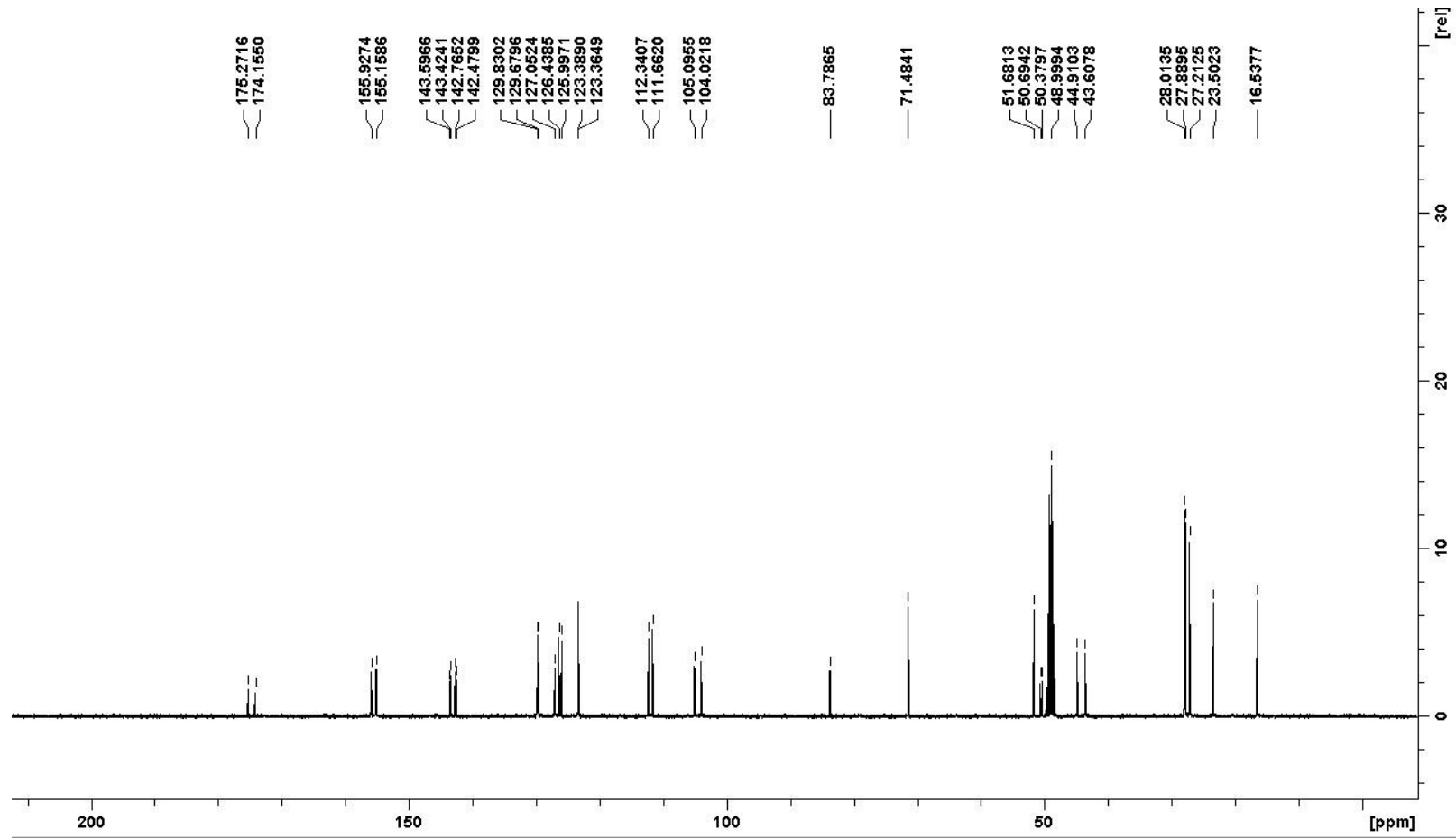


\subsection{THPTA}

\section{Synthetic procedures}
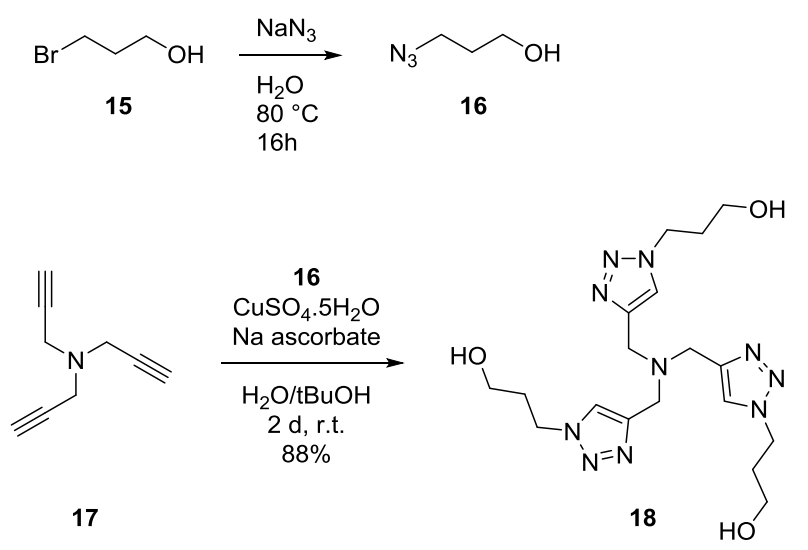

\section{3-azido-1-propanol 16 (CAS 72320-38-8)}

3-azido-1-propanol was prepared following the procedure of Chen et al. ${ }^{6}$

\section{THPTA 18 (CAS 760952-88-3)}

THPTA was prepared using a modified synthetic procedure of Peacock et al. ${ }^{7}$

To solution of tripropargylamine 17 (393 mg, 3 mmol, 1 equiv.) and 3-azido-1-propanol 16 (1.33 g, 12 mmol, 4 equiv.) in a 1:1 $\mathrm{H}_{2} \mathrm{O} / \mathrm{tBuOH}$ mixture $(6 \mathrm{~mL})$ was added $\mathrm{CuSO}_{4} .5 \mathrm{H}_{2} \mathrm{O}(75 \mathrm{mg}, 0.3 \mathrm{mmol}, 0.1$ equiv.) and sodium ascorbate (119 mg, $0.6 \mathrm{mmol}, 0.2$ equiv.). The reaction mixture was stirred at room temperature for 2 days, evaporated to dryness and purified by silica gel column chromatography (gradient up to $30 \% \mathrm{MeOH}$ in $\mathrm{CH}_{2} \mathrm{Cl}_{2}$, detection at $210 \mathrm{~nm})$ to afford THPTA $18(1.15 \mathrm{~g}, 2.64 \mathrm{mmol}, 88 \%$ yield $)$ as a yellow solid.

${ }^{6}$ Chen, P.; Li, C.; Liu, D.; Li, Z. Macromolecules 2012, 45, 9579-9584

${ }^{7}$ Peacock, H.; Maydanovych, O.; Beal, P.A. Org. Lett. 2010, 12, 1044-1047 


\section{Sequences of ORN1 to ORN14}

\begin{tabular}{|c|c|}
\hline ORN1, pre-miR-21 & $\begin{array}{l}\text { UAGCUUAUCAGACUGAUGUUGACUGUUGAAUCUCAUGGCAACACCAG } \\
\text { UCGAUGGGCUGU } \underline{\mathbf{C}}\end{array}$ \\
\hline ORN2, pre-miR-21 & $\begin{array}{l}\text { CAGCUUAUCAGACUGAUGUUGACUGUUGAAUCUCAUGGCAACACCAG } \\
\text { UCGAUGGGCUGUC }\end{array}$ \\
\hline ORN3, pre-miR-21 & $\begin{array}{l}\text { CAGCUUAUCAGACUGAUGUUGACUGUUGAAUCUCAUGGCAACACCAG } \\
\text { UCGAUGGGCUGU } \underline{\mathbf{C}}\end{array}$ \\
\hline ORN4, pre-miR-21 & $\begin{array}{l}\text { UAGCUUAUCAGACUGAUGUUGACUGUUGAAU } \underline{\mathbf{C} U C A U G G C A A C A C C A G} \\
\text { UCGAUGGGCUGU } \underline{\mathbf{C}}\end{array}$ \\
\hline ORN5, pre-miR-21 & 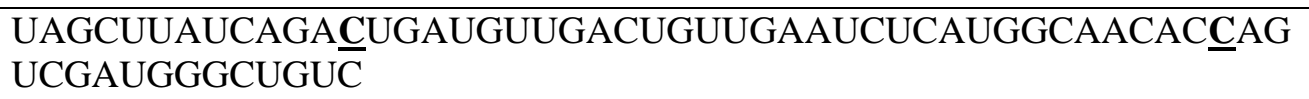 \\
\hline ORN6, pre-miR-21 & $\begin{array}{l}\text { UAGCUUAUCAGA } \underline{\mathbf{C} U G A U G U U G A C U G U U G A A U C U C A U G G C A A C A C C A G} \\
\text { UㅁAAUGGGCUGUC }\end{array}$ \\
\hline ORN7, pre-miR-106a & 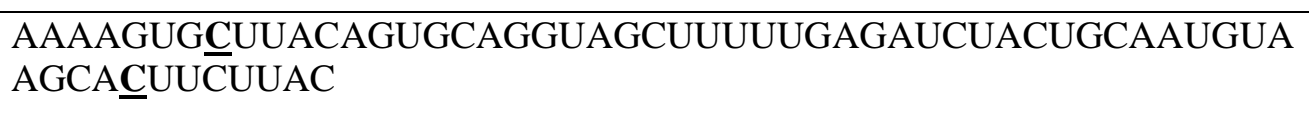 \\
\hline ORN8, pre-miR-106a & $\begin{array}{l}\text { AAAAGUG } \underline{\mathbf{C} U U A C A G U G C A G G U A G C U U U U U G A G A U \underline{\mathbf{C}} U A C U G C A A U G U A} \\
\text { AGCACUUCUUAC }\end{array}$ \\
\hline ORN9, pre-miR-124 & 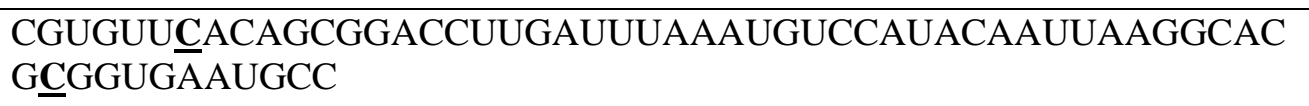 \\
\hline ORN10, pre-miR-124 & 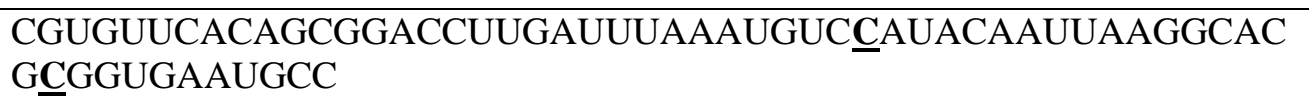 \\
\hline ORN11, pre-miR-20b & 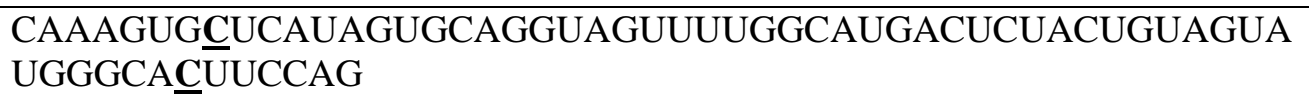 \\
\hline ORN12, pre-miR-20b & $\begin{array}{l}\text { CAAAGUG } \underline{\mathbf{C} U C A U A G U G C A G G U A G U U U U G G \underline{C} A U G A C U C U A C U G U A G U A} \\
\text { UGGGCACUUCCAG }\end{array}$ \\
\hline ORN13, pre-miR-122 & $\begin{array}{l}\text { UGGAGUGUGAㅁAAUGGUGUUUGUGUCUAAACUAUCAAACGCCAUUAU } \\
\text { CAㅡACUAAAUA }\end{array}$ \\
\hline ORN14, pre-miR-122 & 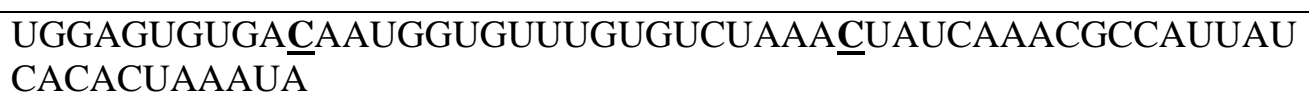 \\
\hline
\end{tabular}




\section{LCMS traces of ORN1 to ORN14}

\section{ORN1-N 3 , pre-miR-21}

UAGCUUAUCAGACUGAUGUUGACUGUUGAAUCUCAUGGCAACACCAGUCGAUGGGCUGU드

Mass calculated 19381.72, found 19379.63

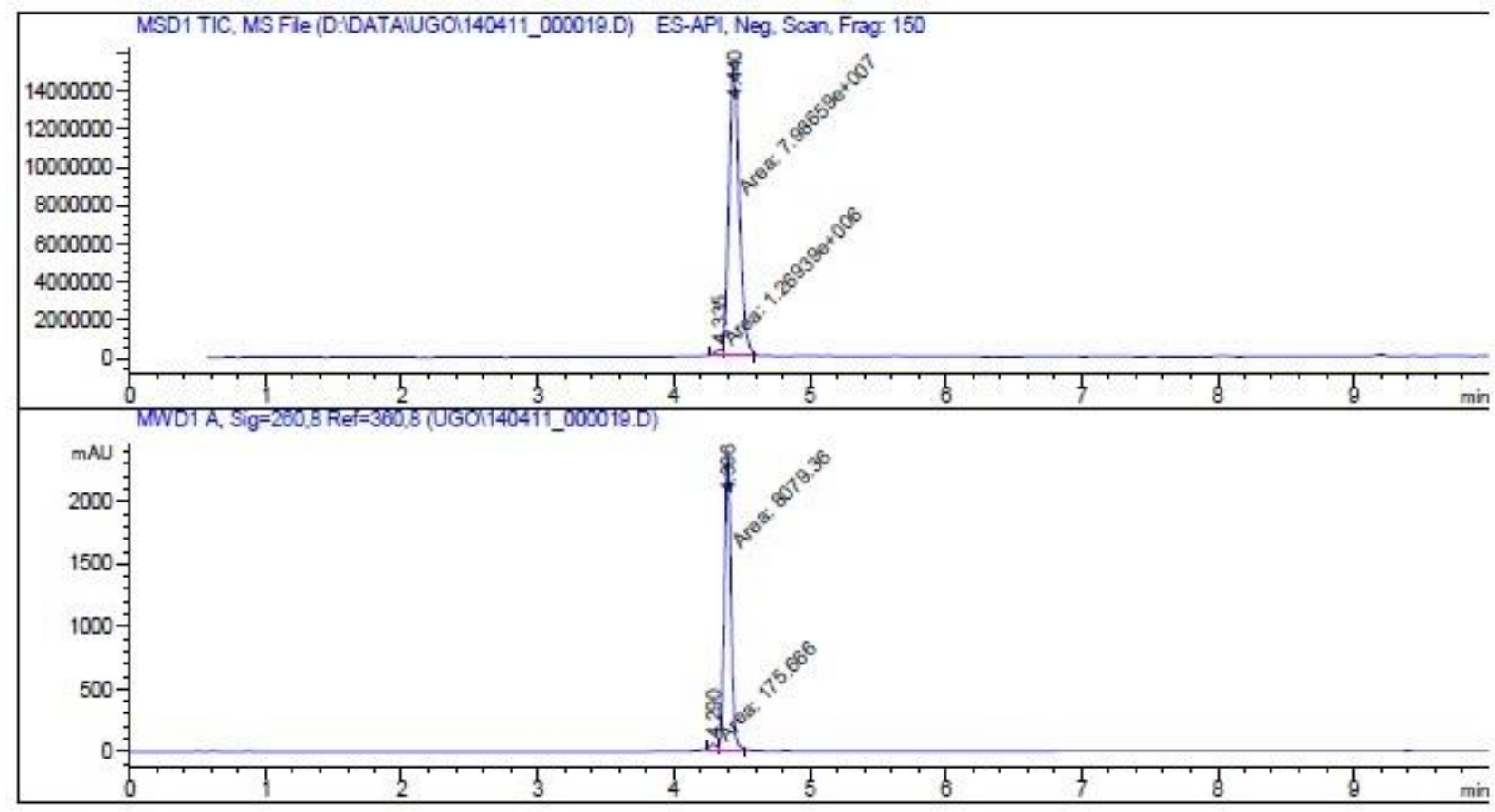

Signal 1: MSD1 TIC, MS File

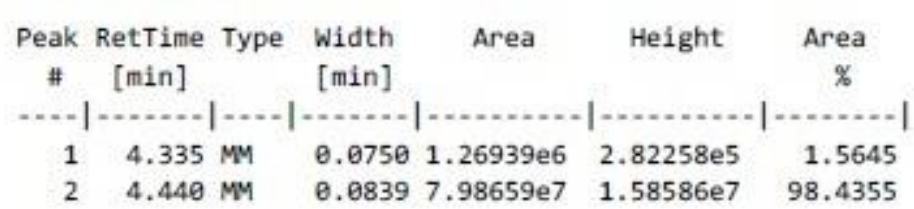

Totals :

$8.11353 \mathrm{e} 7 \quad 1.61408 \mathrm{e} 7$

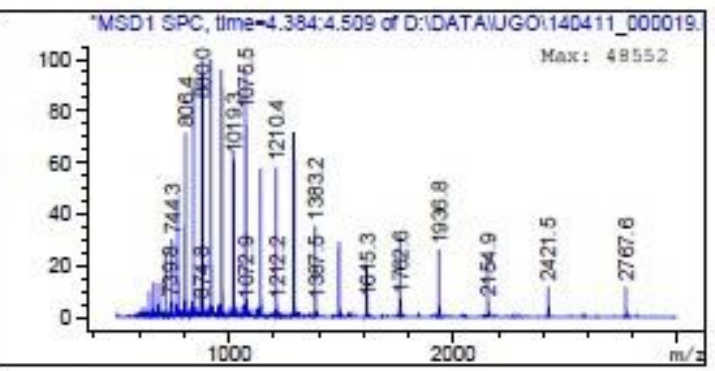

Signal 2: MWD1 A, Sig $=260,8 \quad \operatorname{Ref}=360,8$

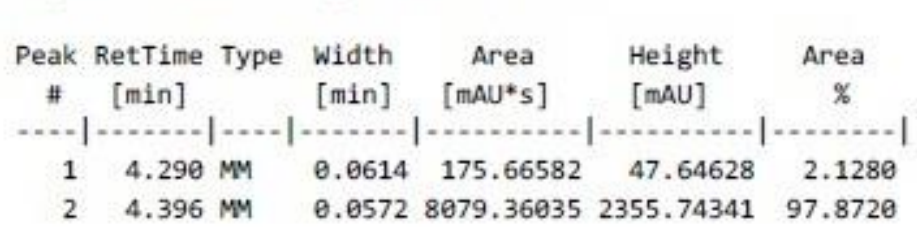

Totals :

$8255.02617 \quad 2403.38969$

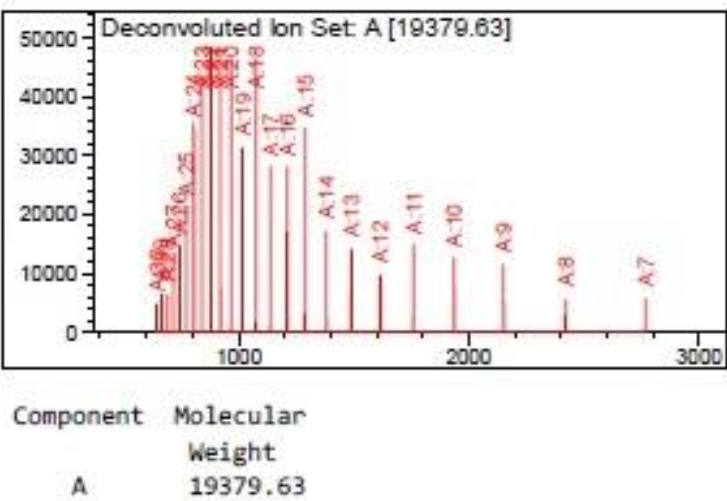


ORN1-Cy5, pre-miR-21

UAGCUUAUCAGACUGAUGUUGACUGUUGAAUCUCAUGGCAACACCAGUCGAUGGGCUGU $\underline{\mathbf{C}}$

Mass calculated 19938.48, found 19939.31

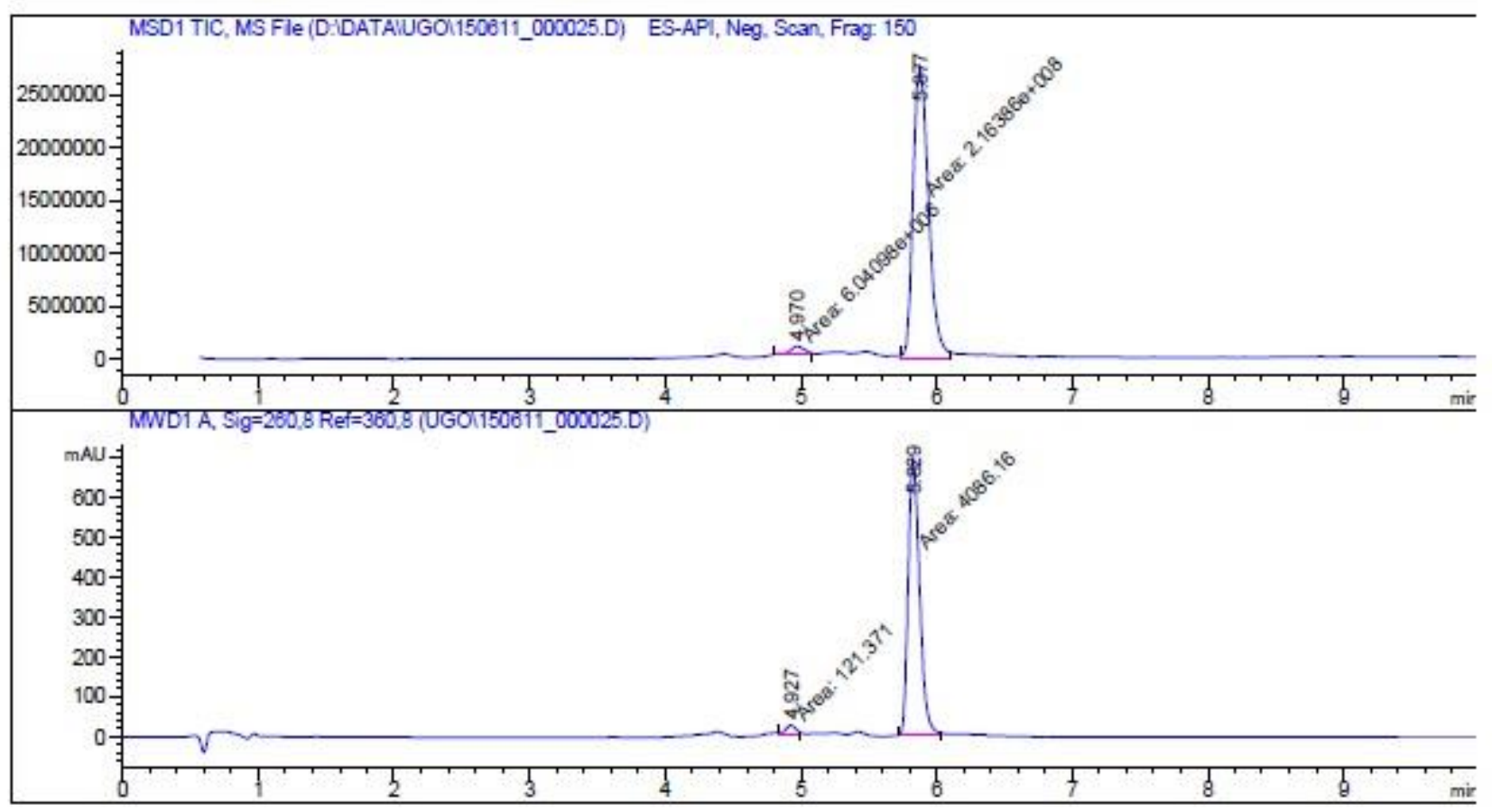

Signal 1: MSD1 TIC, MS File

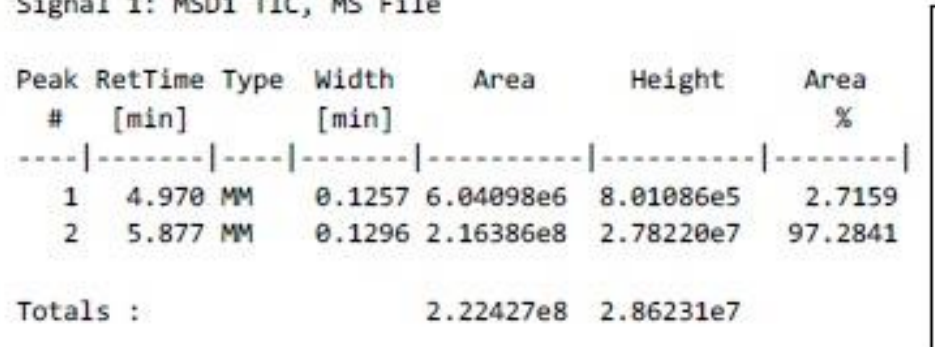

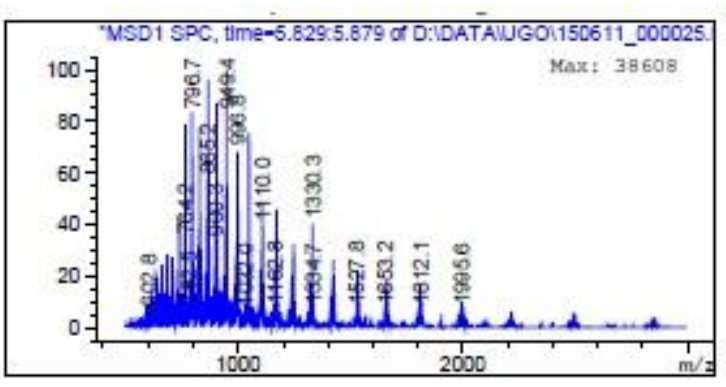

Signal 2: MWD1 A, $S i g=260,8$ Ref $=360,8$

\begin{tabular}{|c|c|c|c|c|c|c|}
\hline $\begin{array}{c}\text { Peak } \\
\#\end{array}$ & $\begin{array}{c}\text { RetTime } \\
\text { [min] }\end{array}$ & Type & $\begin{array}{l}\text { Width } \\
\text { [min] }\end{array}$ & $\begin{array}{c}\text { Area } \\
\text { [mAU*s] }\end{array}$ & $\begin{array}{l}\text { Height } \\
\text { [mAU] }\end{array}$ & $\begin{array}{c}\text { Area } \\
\%\end{array}$ \\
\hline & & & & & & . \\
\hline 1 & 4.927 & MM & 0.0877 & 121.37056 & 23.07008 & 2.8846 \\
\hline 2 & 5.829 & MM & 0.0980 & 4086.15991 & 694.84058 & 97.1154 \\
\hline
\end{tabular}

Totals :

$4207.53847 \quad 717.91066$

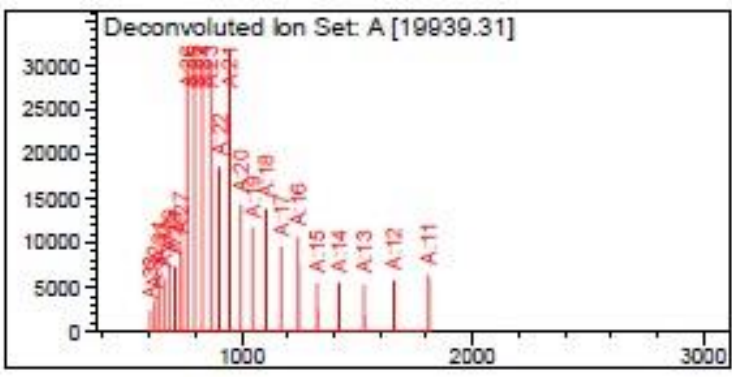

$\begin{array}{cl}\text { Component } & \begin{array}{c}\text { Molecular } \\ \text { Weight }\end{array} \\ \text { A } & 19939.31\end{array}$ 


\section{ORN2-N3, pre-miR-21}

CAGCUUAUCAGACUGAUGUUGACUGUUGAAUCUCAUGGCAACACCAGUCGAUGGGCUGUC

Mass calculated 19380.72, found 19379.85

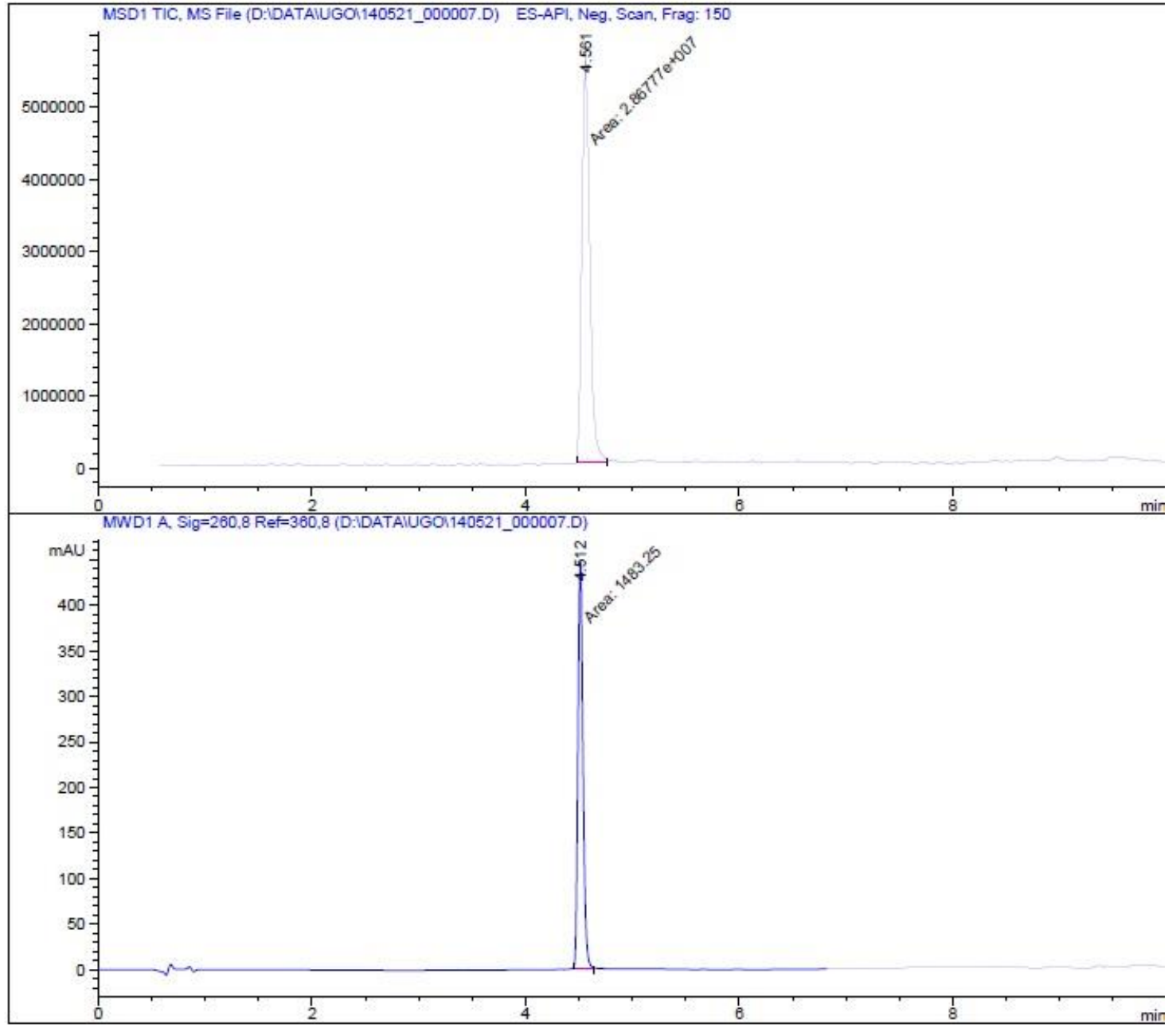

Signal 1: MSD1 TIC, MS File

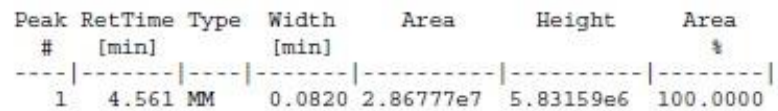

Totals : $\quad 2.86777 \mathrm{e} \quad 5.83159 \mathrm{e} 6$

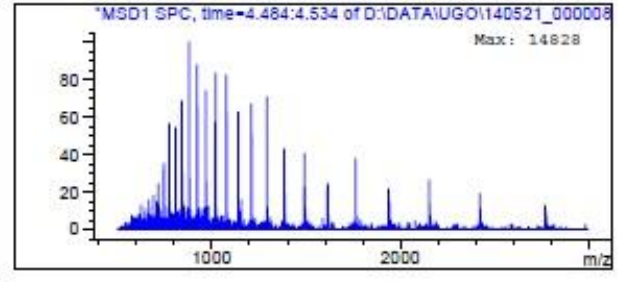

Signal 2: MWD1 A, $\operatorname{Sig}=260,8$ Ref $=360,8$
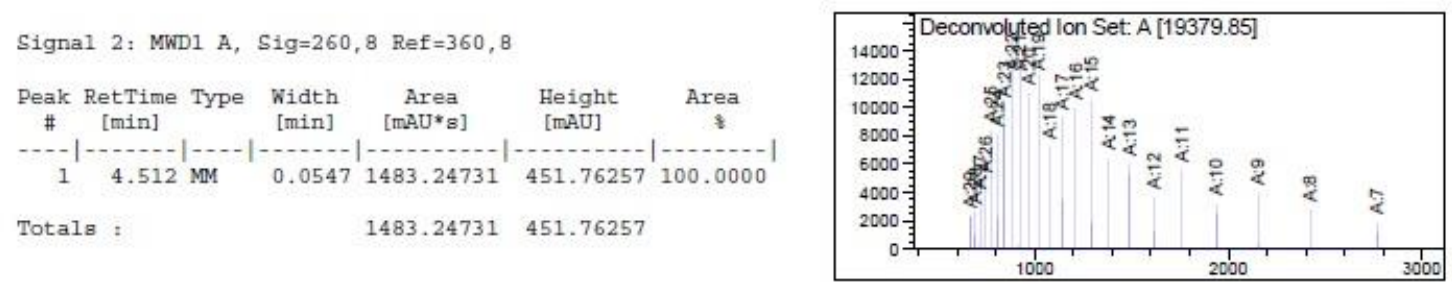

Component Molecular

A $\quad 19379.85$ 


\section{ORN2-Cy3, pre-miR-21}

CAGCUUAUCAGACUGAUGUUGACUGUUGAAUCUCAUGGCAACACCAGUCGAUGGGCUGUC

Mass calculated 19911.44, found 19910.22

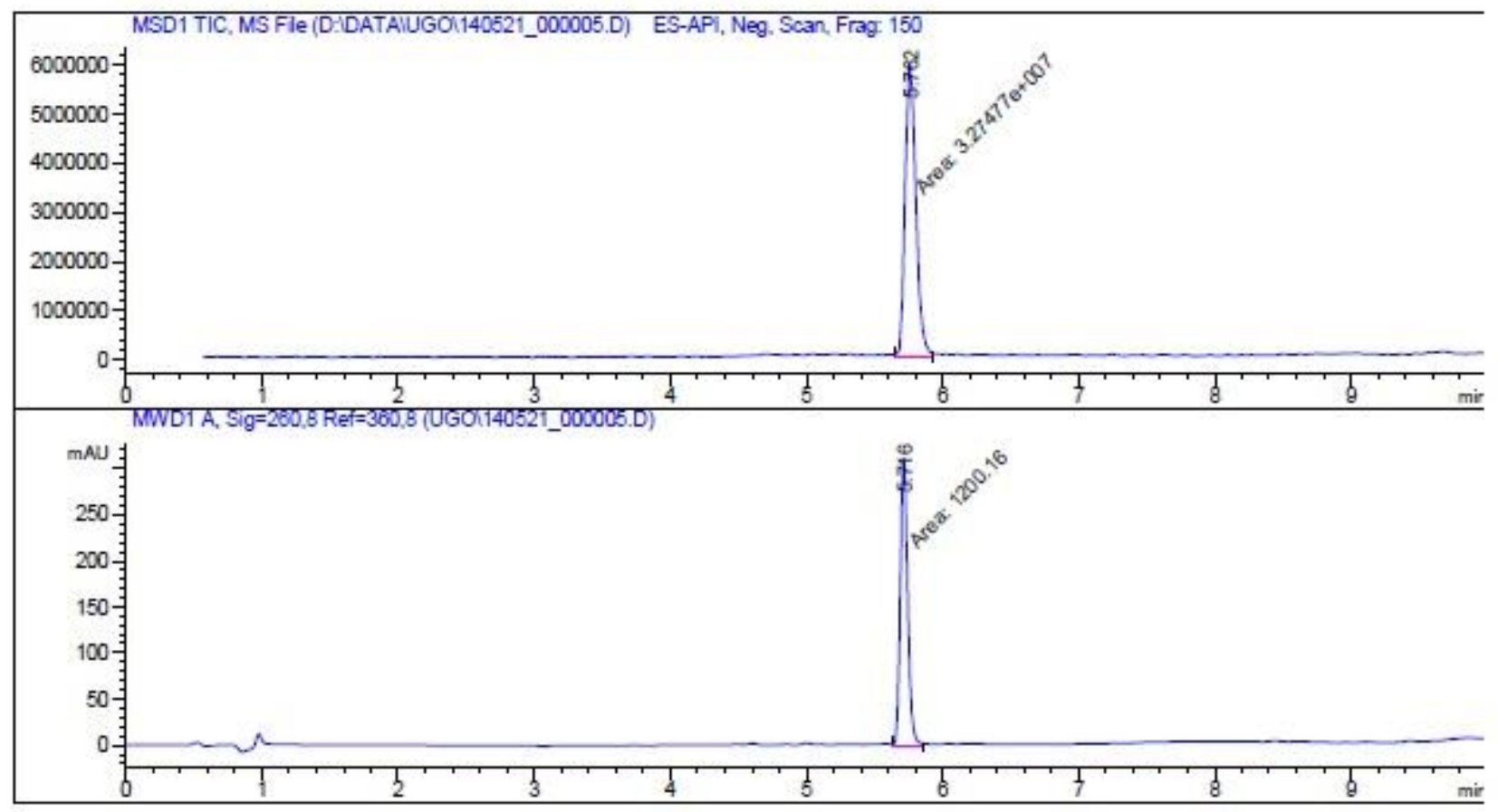

Signal 1: MSD1 TIC, MS File

Peak RetTime Type Width Area Height Area

\# [min] [min] $\%$

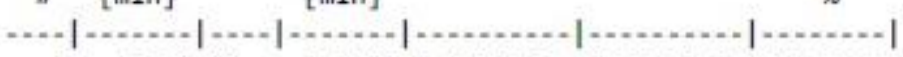

$\begin{array}{lllllll}1 & 5.762 & \text { MM } & 0.0878 & 3.27477 \mathrm{e} 7 & 6.21792 \mathrm{e} & 100.0000\end{array}$

Totals :

$3.27477 \mathrm{e} \quad 6.21793 \mathrm{e} 6$

Signal 2: MWD1 A, Sig=260,8 Ref $=360,8$

Peak RetTime Type width Area Height Area

\# [min] [min] [mAU*s] [mAU] $\%$

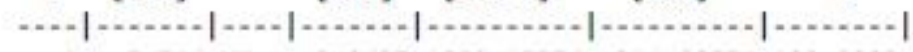

$\begin{array}{lllllll}1 & 5.716 \text { MM } & 0.0637 & 1200.15576 & 314.08551 & 100.0000\end{array}$

Totals :

$1200.15576 \quad 314.08551$
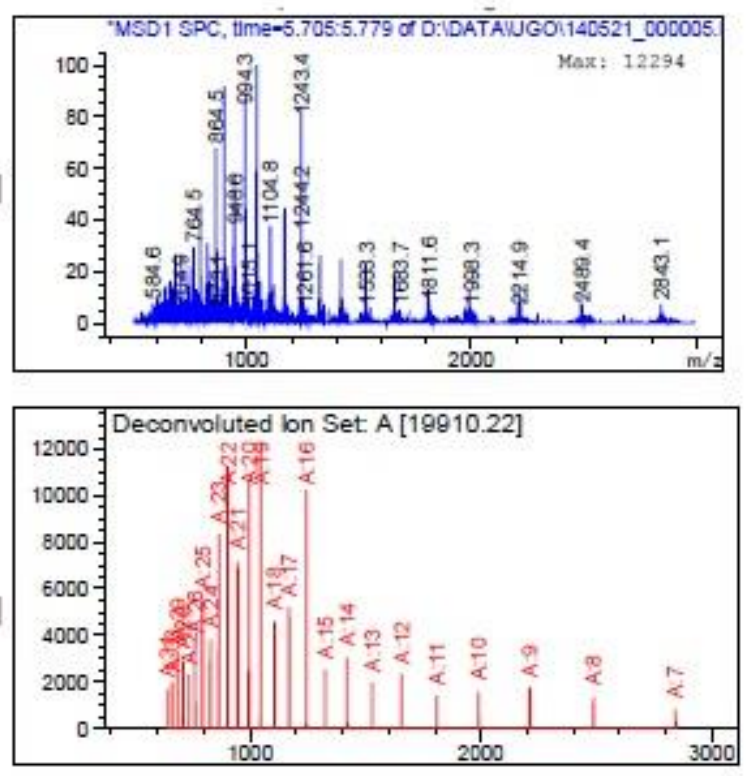

Component Molecular

Weight

A $\quad 19910.22$ 


\section{ORN2-Cy5, pre-miR-21}

CAGCUUAUCAGACUGAUGUUGACUGUUGAAUCUCAUGGCAACACCAGUCGAUGGGCUGUC

Mass calculated 19937.48, found 19936.63

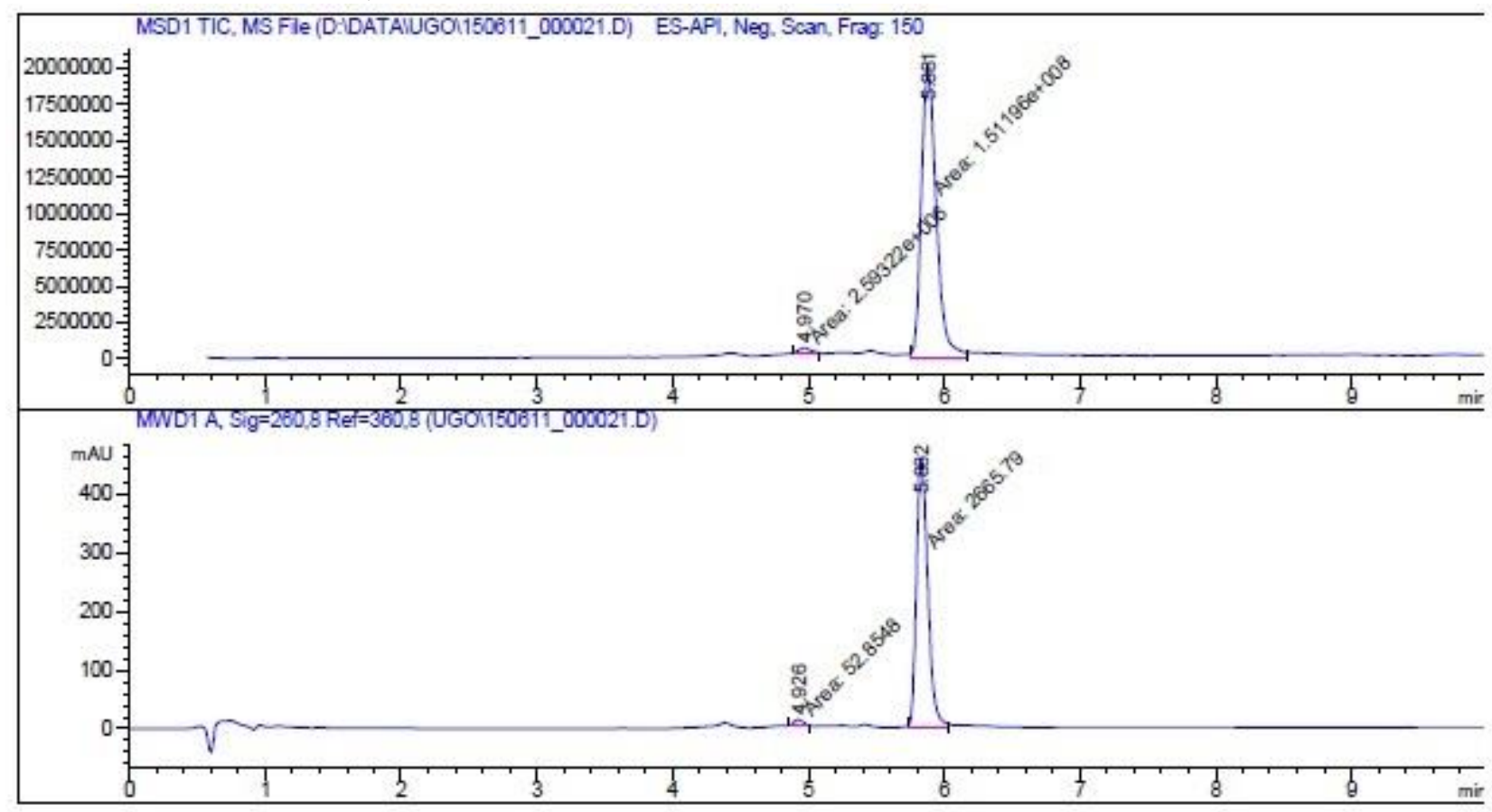

Signal 1: MSD1 TIC, MS File

\begin{tabular}{|c|c|c|c|c|c|c|}
\hline $\begin{array}{c}\text { Peak } \\
\#\end{array}$ & $\begin{array}{l}\text { RetTime } \\
\text { [min] }\end{array}$ & Type & $\begin{array}{l}\text { Width } \\
\text { [min] }\end{array}$ & Area & Height & $\begin{array}{c}\text { Area } \\
\%\end{array}$ \\
\hline$\cdots$ & |.... & & ........ & $\cdots$ & 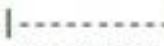 & $\ldots . . . .$. \\
\hline 1 & 4.970 & MM & 0.1088 & $2.59322 \mathrm{e} 6$ & $3.97135 \mathrm{e} 5$ & 1.6862 \\
\hline 2 & 5.881 & MM & 0.1240 & $1.51196 \mathrm{e} 8$ & $2.03205 \mathrm{e} 7$ & 98.3138 \\
\hline
\end{tabular}

Totals :

$$
1.53789 \mathrm{e} \quad 2.07176 \mathrm{e} 7
$$

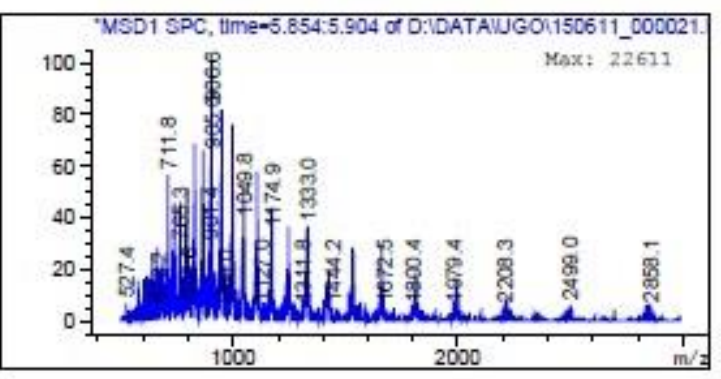

Signal 2: MWD1 A, Sig $=260,8$ Ref $=360,8$

\begin{tabular}{cccccc}
$\begin{array}{c}\text { Peak RetTime Type Width } \\
\text { \# } \begin{array}{l}\text { [min] } \\
\text { [min] }\end{array}\end{array}$ & $\begin{array}{c}\text { Area } \\
\text { [mAU*s] }\end{array}$ & $\begin{array}{l}\text { Height } \\
\text { [mAU] }\end{array}$ & \multicolumn{1}{c}{$\begin{array}{c}\text { Area } \\
\%\end{array}$} \\
\hline 1 & 4.926 MM & 0.0832 & 52.85483 & 10.59320 & 1.9442 \\
2 & 5.832 MM & 0.0970 & 2665.78882 & 457.91339 & 98.0558
\end{tabular}

Totals :

$2718.64365 \quad 468.50659$

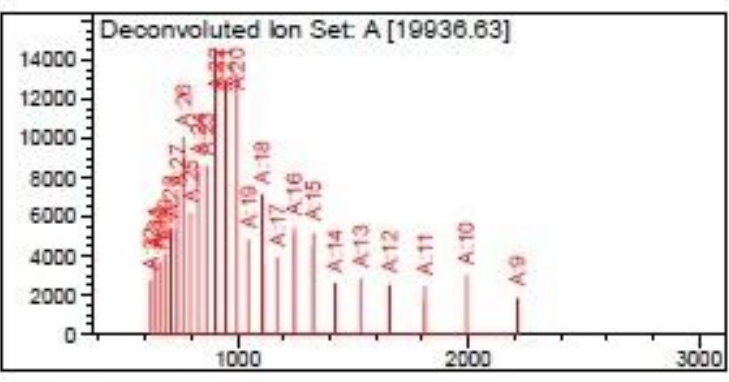

$$
\begin{array}{cl}
\text { Component } & \begin{array}{l}
\text { Molecular } \\
\text { Weight }
\end{array} \\
\text { A } & 19936.63
\end{array}
$$




\section{ORN3-Cy3/N 3 , pre-miR-21}

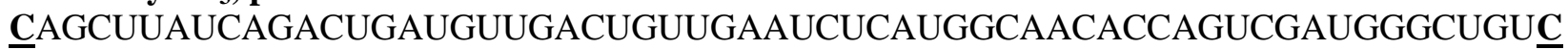

Mass calculated 19980.52, found 19980.11

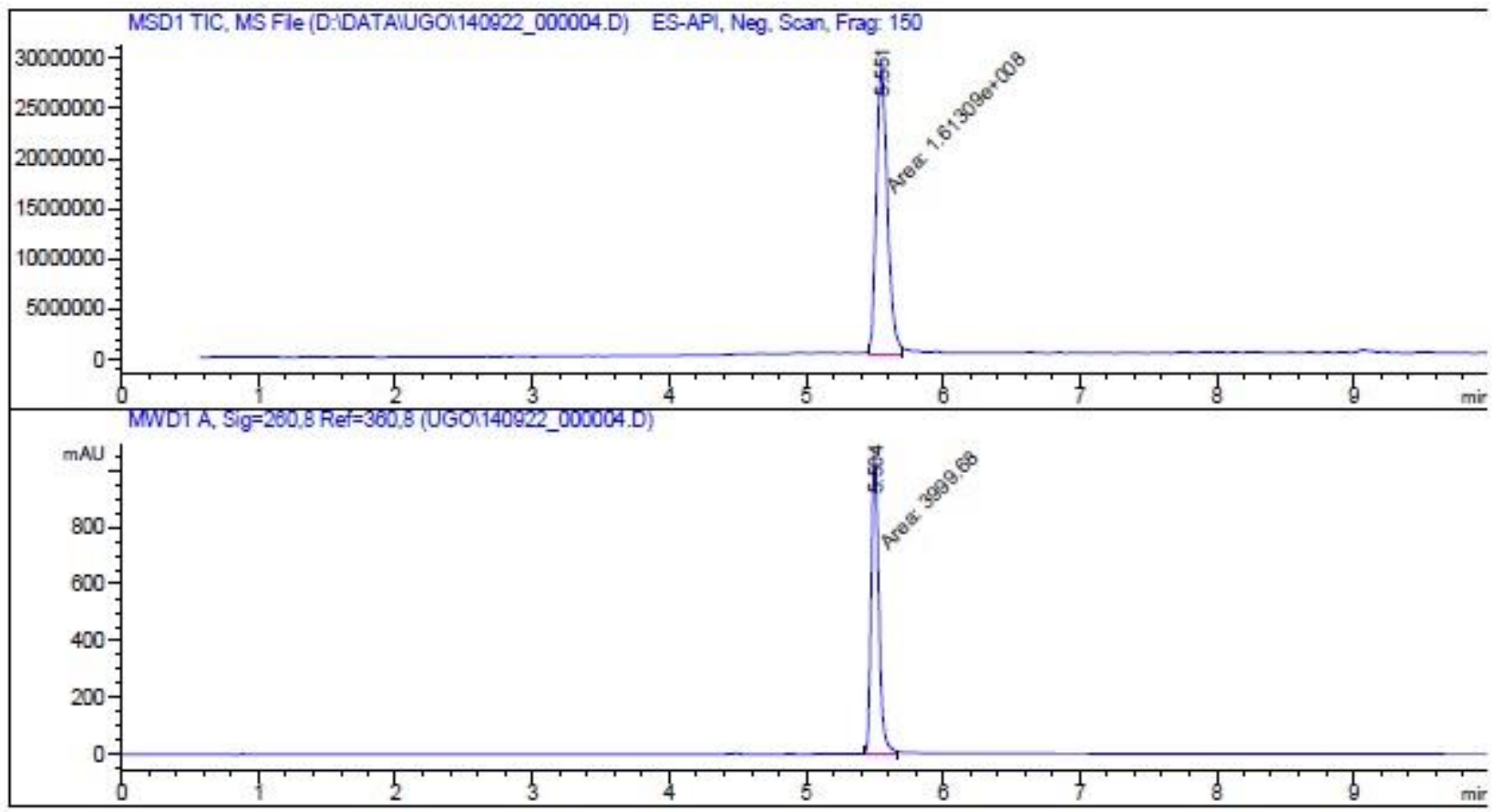

Signal 1: MSD1 TIC, MS File
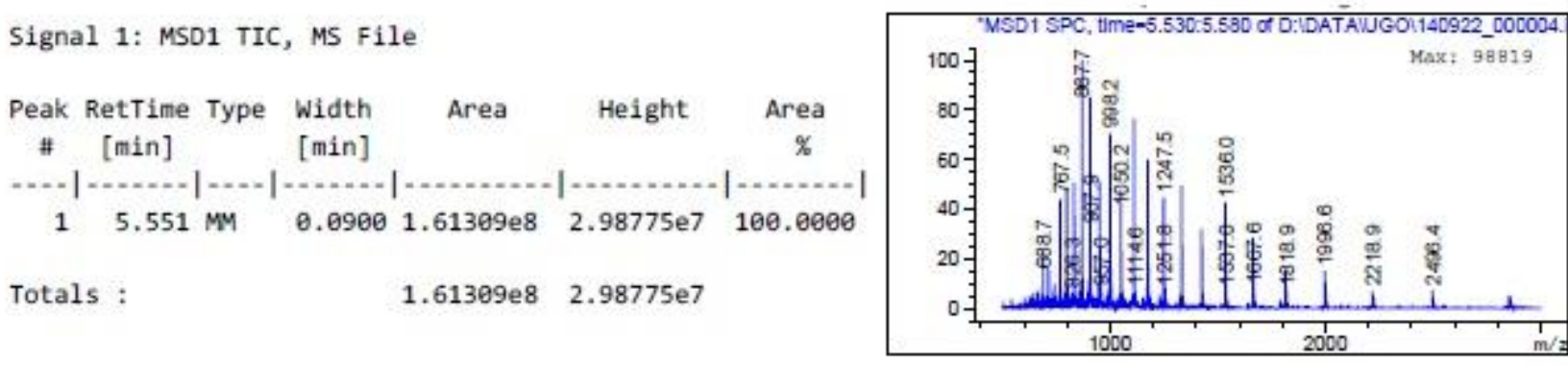

Signal 2: MWD1 A, Sig $=260,8$ Ref $=360,8$

\begin{tabular}{|c|c|c|c|c|c|}
\hline $\begin{array}{c}\text { Peak } \\
\#\end{array}$ & $\begin{array}{l}\text { RetTime Type } \\
\text { [min] }\end{array}$ & $\begin{array}{l}\text { Width } \\
\text { [min] }\end{array}$ & $\begin{array}{c}\text { Area } \\
\text { [mAU*s] }\end{array}$ & $\begin{array}{l}\text { Height } \\
\text { [mAU] }\end{array}$ & $\begin{array}{c}\text { Area } \\
\%\end{array}$ \\
\hline 1 & $-2-1=$ & a & 399968498 & 1943 & 199 \\
\hline
\end{tabular}

Totals :

3999.684081043 .41150

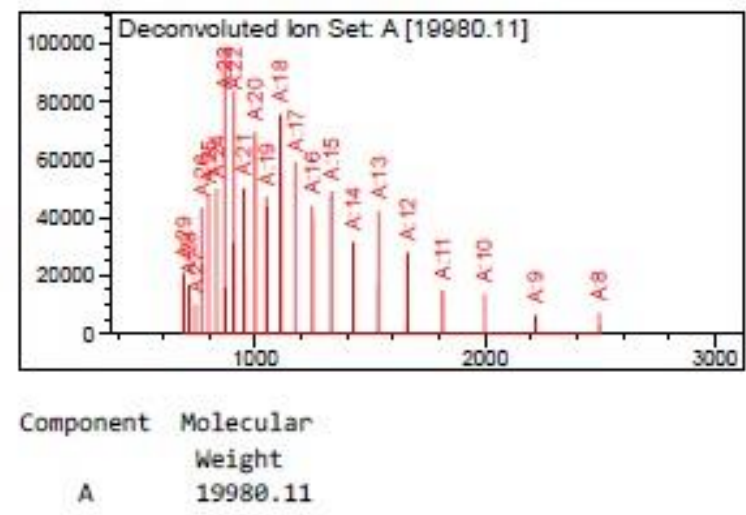




\section{ORN3-Cy3/Cy5, pre-miR-21}

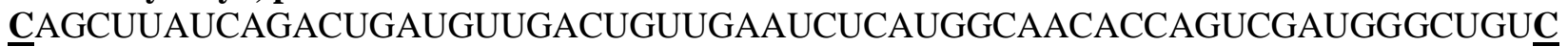

Mass calculated 20537.28, found 20537.65
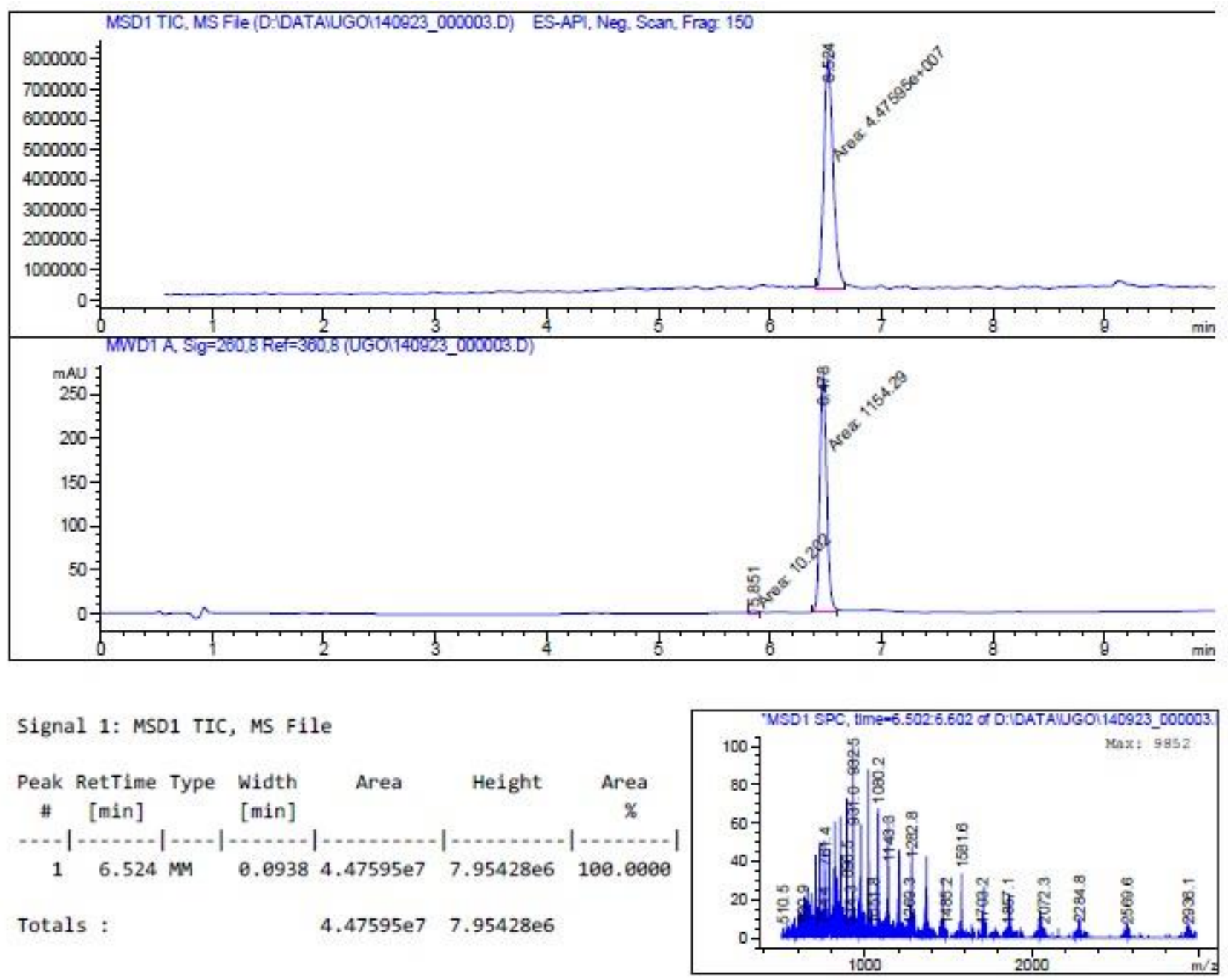

Signal 2: MWD1 A, $S i g=260,8$ Ref $=360,8$

\begin{tabular}{|c|c|c|c|c|c|c|}
\hline $\begin{array}{c}\text { Peak } \\
\#\end{array}$ & $\begin{array}{c}\text { RetTime } \\
\text { [min] }\end{array}$ & Type & $\begin{array}{l}\text { Width } \\
\text { [min] }\end{array}$ & $\begin{array}{c}\text { Area } \\
{\left[\mathrm{mAU}^{*} s\right]}\end{array}$ & $\begin{array}{l}\text { Height } \\
\text { [mAU] }\end{array}$ & $\begin{array}{c}\text { Area } \\
\%\end{array}$ \\
\hline & & & 3 & & & \\
\hline & 47 & & 7 & 10.20190 & & \\
\hline & 6.478 & & 112 & 1154.28833 & 270.01978 & 99.1239 \\
\hline
\end{tabular}

Totals :

$1164.49031 \quad 272.58550$

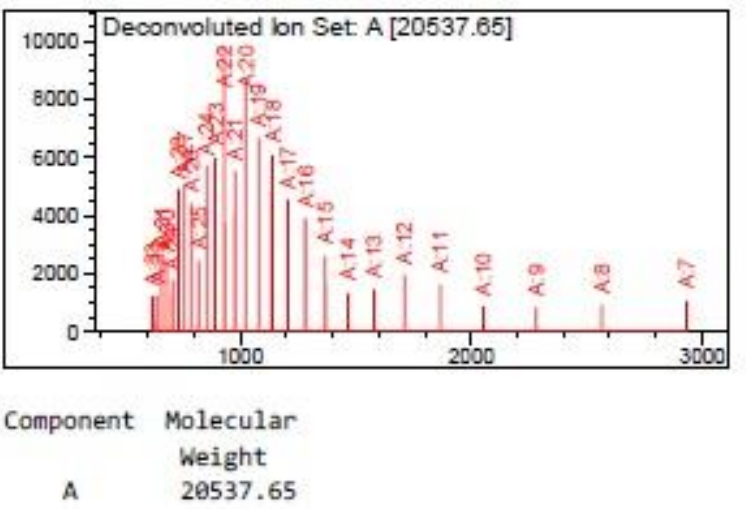


ORN4-Cy3/ $\mathbf{N}_{3}$, pre-miR-21

UAGCUUAUCAGACUGAUGUUGACUGUUGAAUCUCAUGGCAACACCAGUCGAUGGGCUGU므

Mass calculated 19981.52, found 19980.83

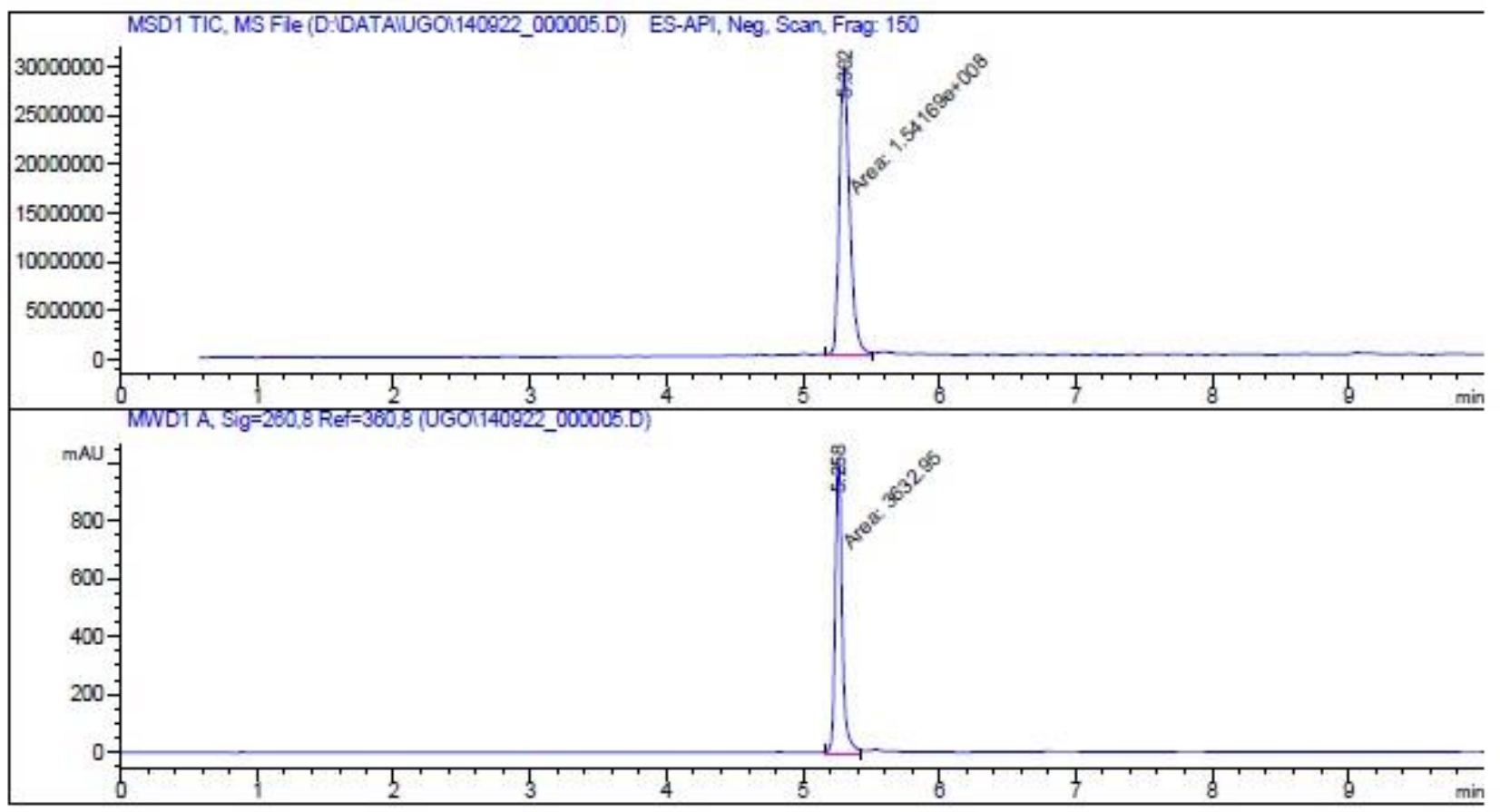

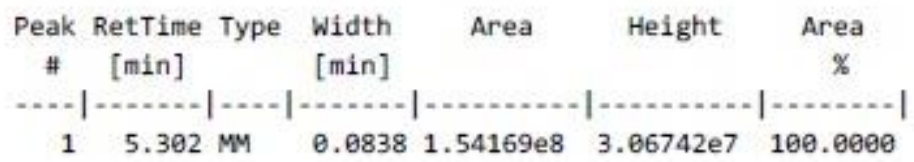

Totals :

$1.54169 \mathrm{e} \quad 3.06742 \mathrm{e} 7$

Signal 2: MWD1 A, Sig $=260,8$ Ref $=360,8$

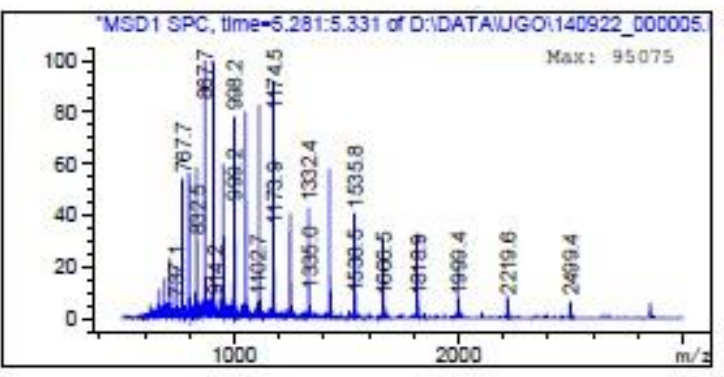

Peak RetTime Type Width Area Height Area \# [min] [min] [mAU*s] [mAU]

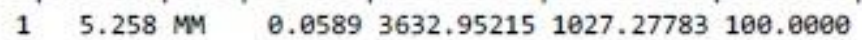

Totals :

3632.952151027 .27783

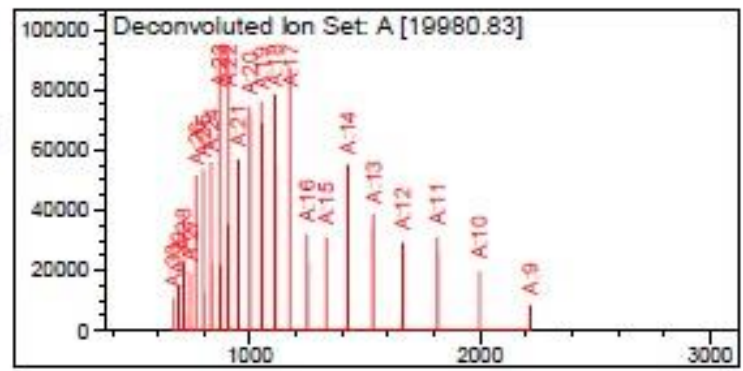

Component Molecular Weight

A $\quad 19980.83$ 


\section{ORN4-Cy3/Cy5, pre-miR-21}

UAGCUUAUCAGACUGAUGUUGACUGUUGAAUCUCAUGGCAACACCAGUCGAUGGGCUGU $\underline{\mathbf{C}}$

Mass calculated 20538.28, found 20538.48

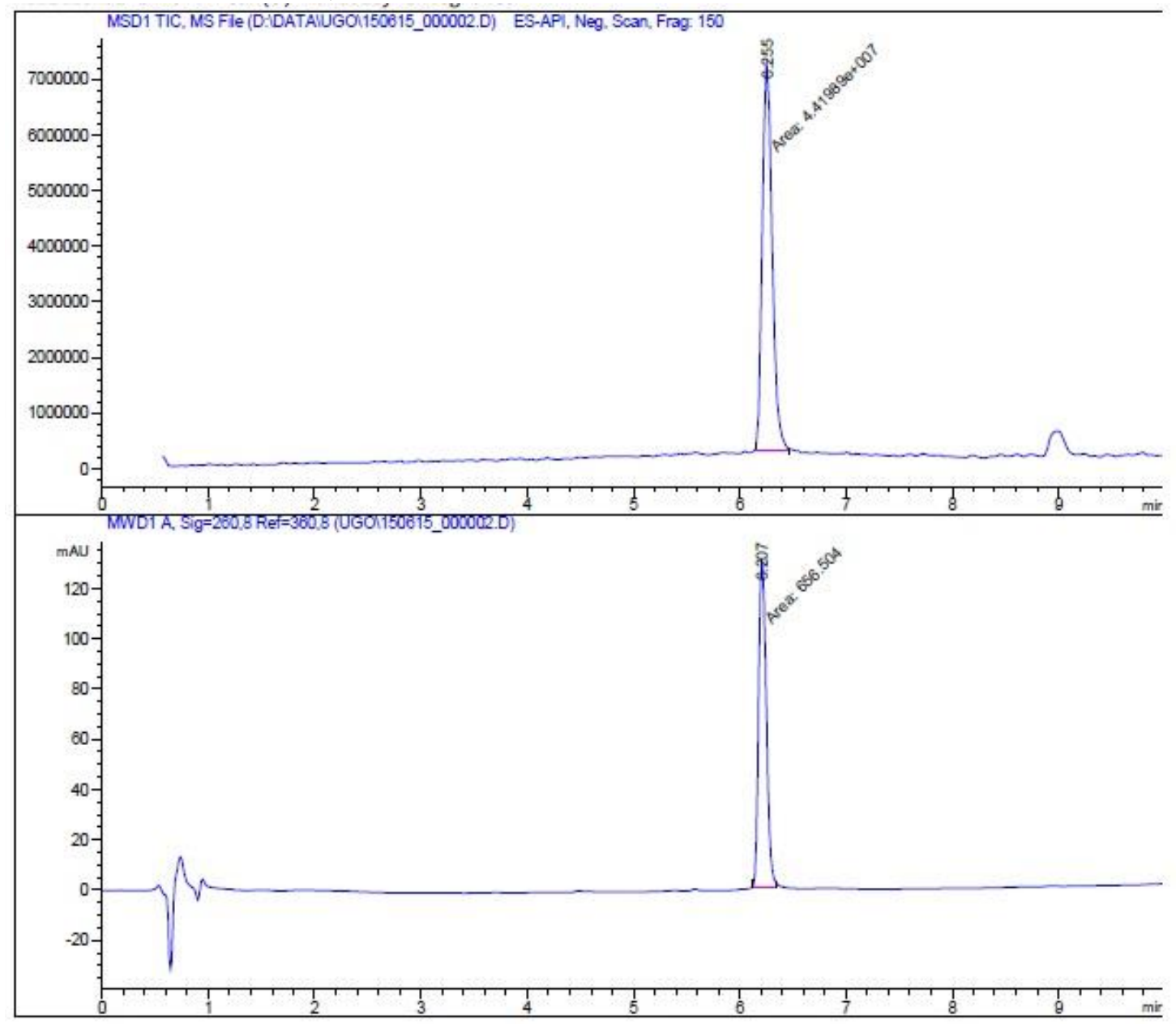

Signal 1: MSD1 TIC, MS File

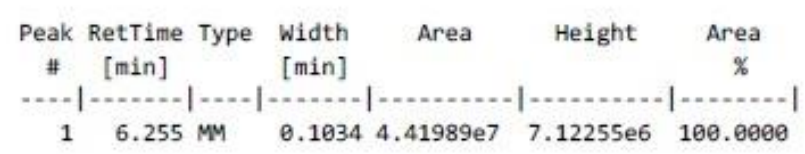

Totals :

$4.41989 \mathrm{e} 7 \quad 7.12255 \mathrm{e} 6$

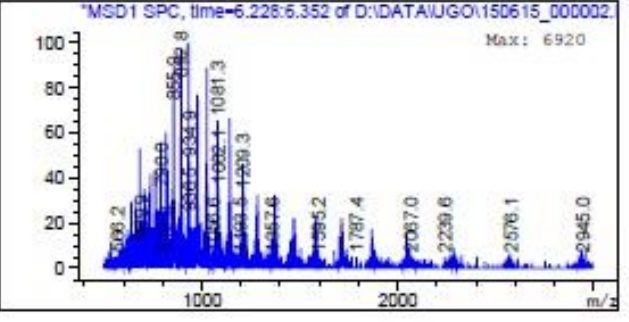

Signal 2: MWD1 A, Sig=260, 8 Ref $=360,8$

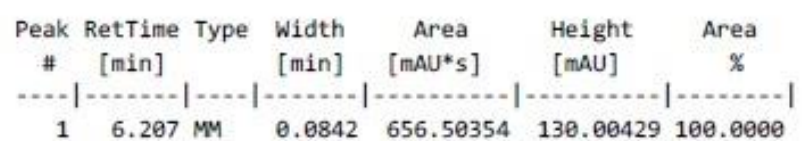

$\begin{array}{lllllll}1 & 6.207 & \text { MM } & 0.0842 & 656.50354 & 130.00429 & 100.0000\end{array}$

Totals :

656.50354130 .00429

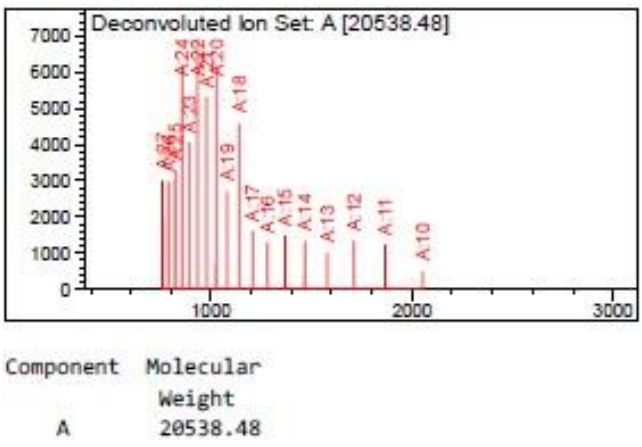




\section{ORN5-Cy3/N3, pre-miR-21}

UAGCUUAUCAGA $\underline{\mathbf{C} U G A U G U U G A C U G U U G A A U C U C A U G G C A A C A C \underline{C} A G U C G A U G G G C U G U C}$

Mass calculated 19981.52, found 19980.29

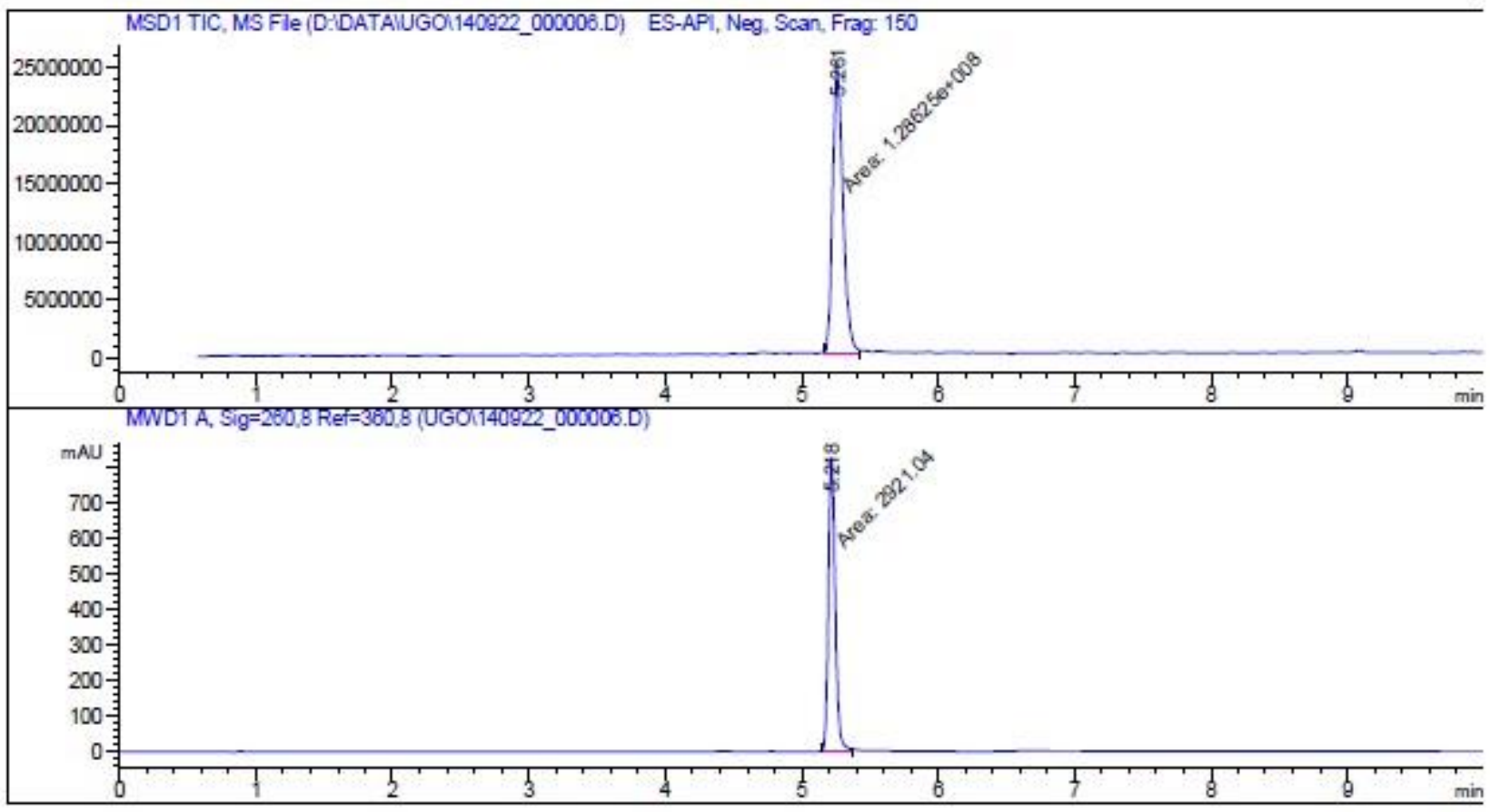

Signal 1: MSD1 TIC, MS File

$\begin{array}{cccc}\text { Peak RetTime Type width Area Height } & \text { Area } \\ \text { \# [min] } & {[\text { min] }} & & \%\end{array}$

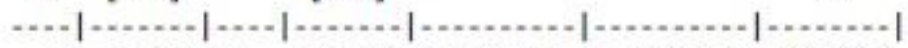

$\begin{array}{lllllll}1 & 5.261 & \text { MM } & 0.0829 & 1.28625 \mathrm{e} 8 & 2.58583 \mathrm{e} 7 & 100.0000\end{array}$

Totals : $\quad 1.28625 \mathrm{e} 8 \quad 2.58583 \mathrm{e} 7$

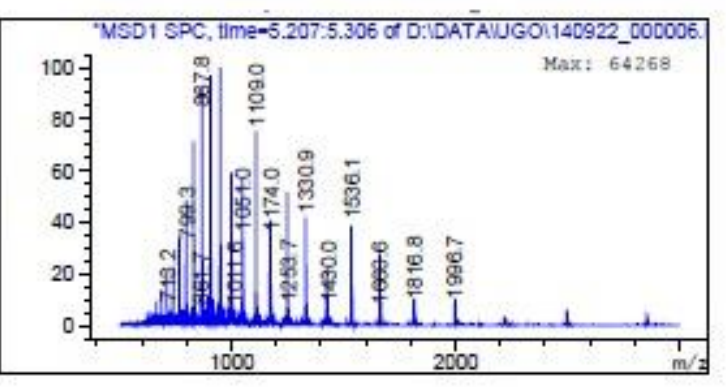

Signal 2: MWD1 A, Sig $=260,8$ Ref $=360,8$

Peak RetTime Type width Area Height Area

\# [min] [min] [mAU*s] [MAU] $\%$

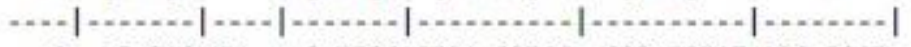

$\begin{array}{llllll}1 & 5.218 \mathrm{MM} & 0.0584 & 2921.03760 \quad 833.48517 & 100.0000\end{array}$

Totals :

$2921.03760 \quad 833.48517$

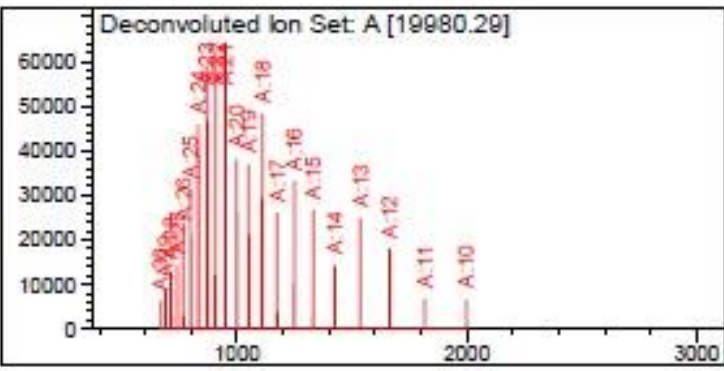

Component Molecular

Weight

A $\quad 19980.29$ 


\section{ORN5-Cy3/Cy5, pre-miR-21}

UAGCUUAUCAGA $\underline{\mathbf{C} U G A U G U U G A C U G U U G A A U C U C A U G G C A A C A C \underline{C} A G U C G A U G G G C U G U C}$

Mass calculated 20538.28, found 20537.65
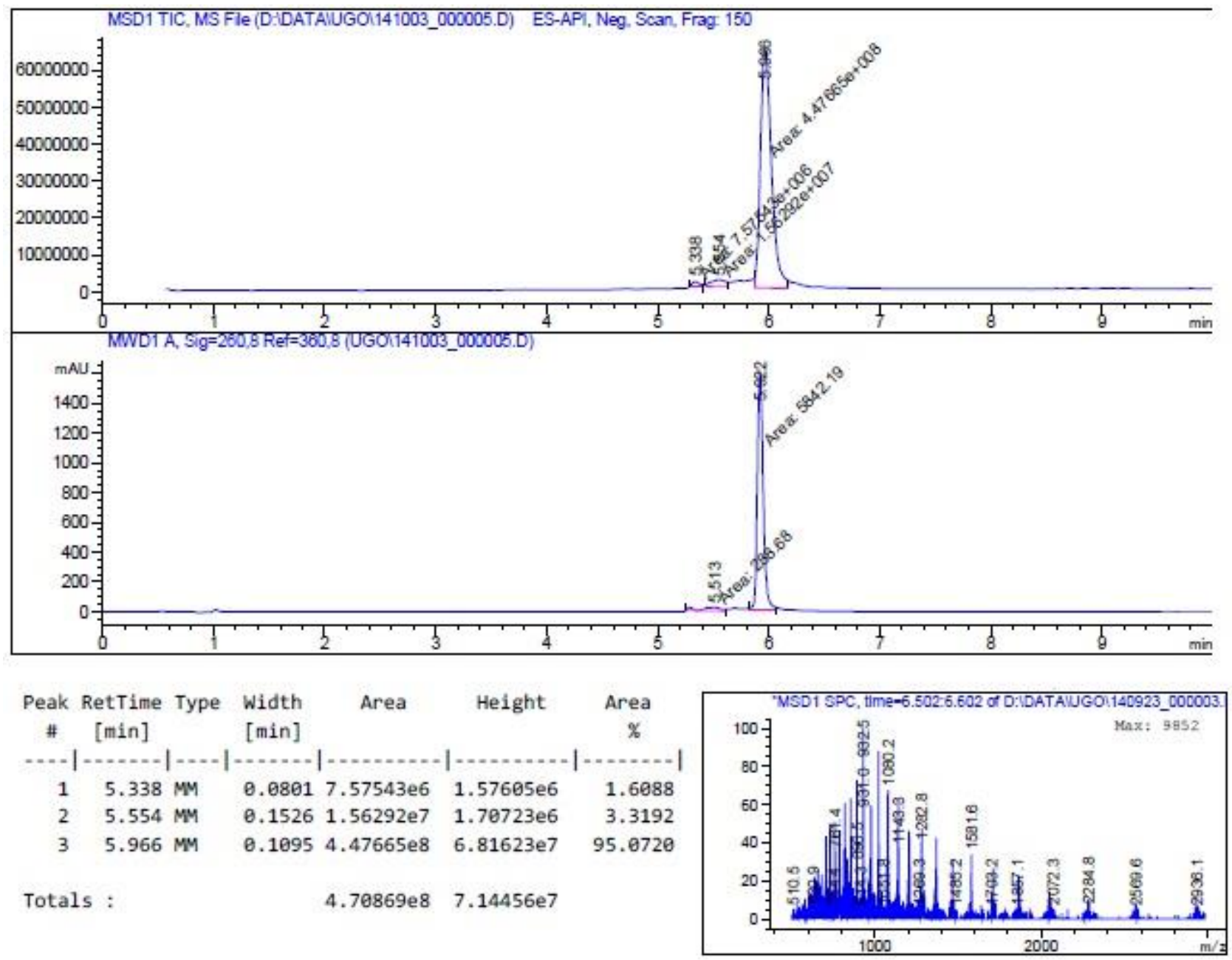

Signal 2: MWD1 A, Sig=260,8 Ref $=360,8$

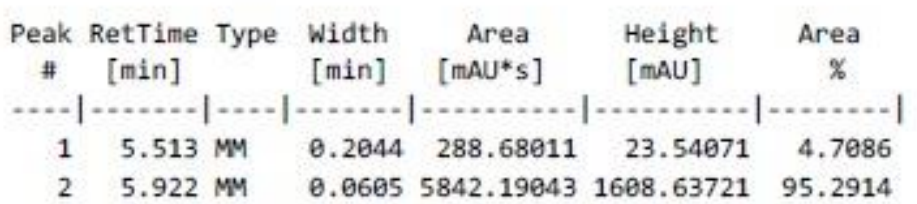

Totals :

6130.879541632 .17792

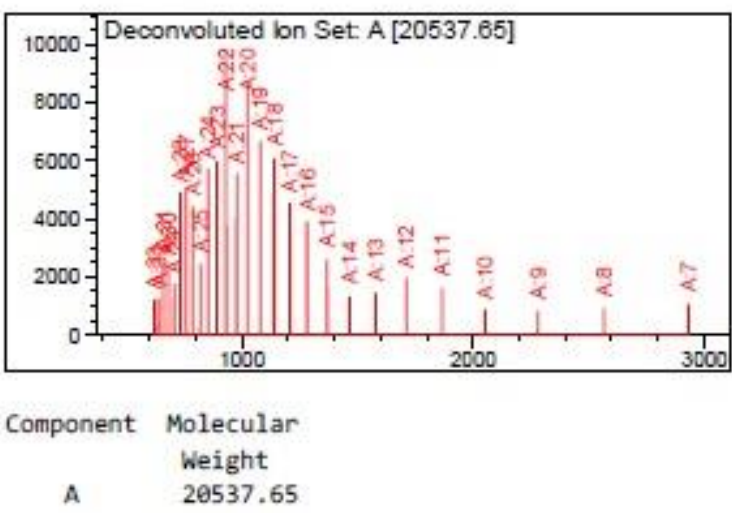


ORN6-Cy3/N3, pre-miR-21

UAGCUUAUCAGACUGAUGUUGACUGUUGAAUCUCAUGGCAACACCAGUCGAUGGGCUGUC

Mass calculated 19981.52, found 19979.70

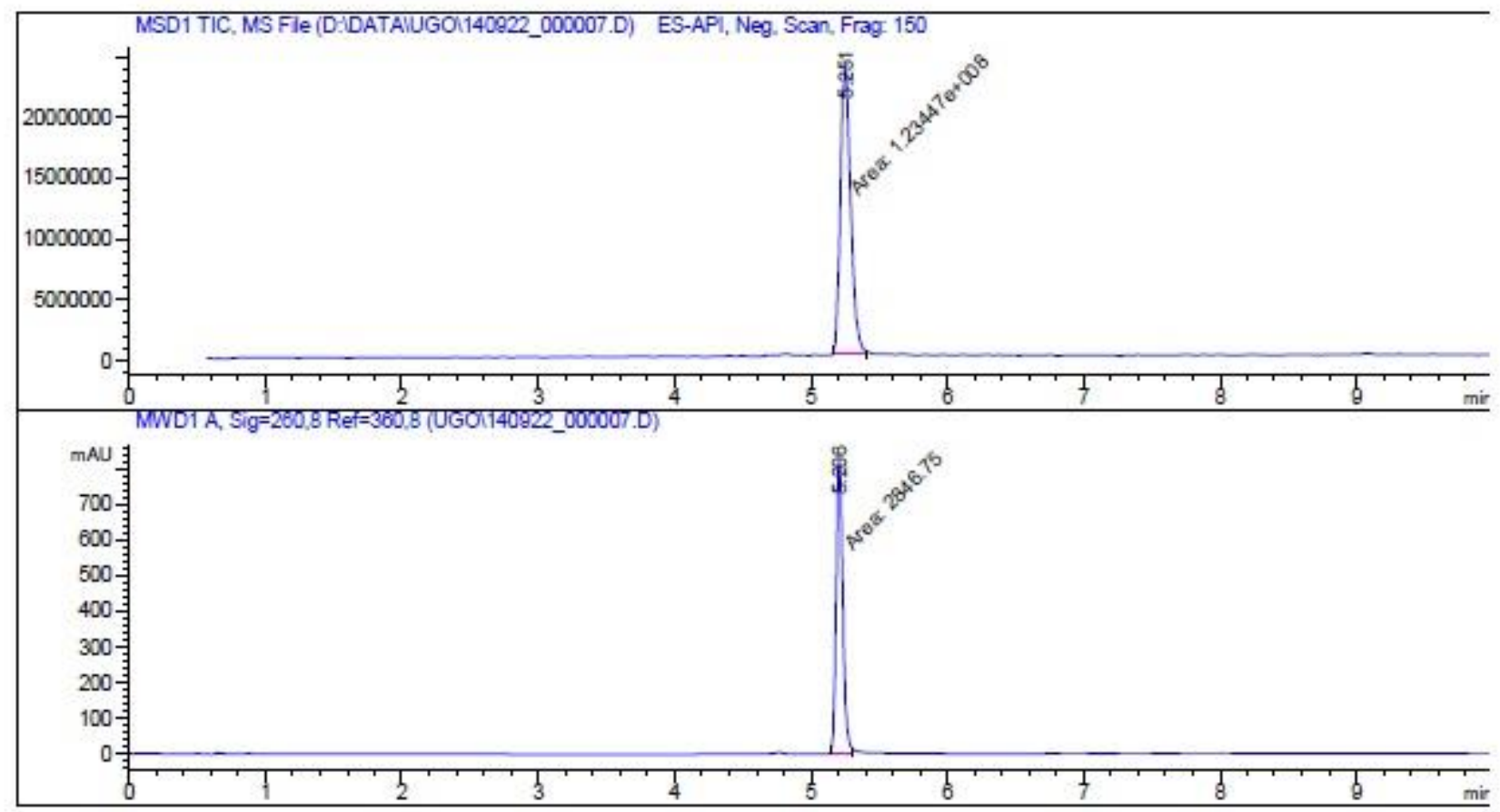

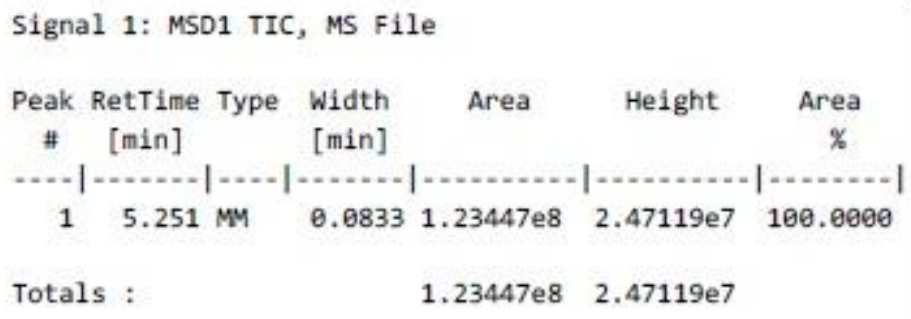

Signal 2: MWD1 A, Sig=260, 8 Ref $=360,8$

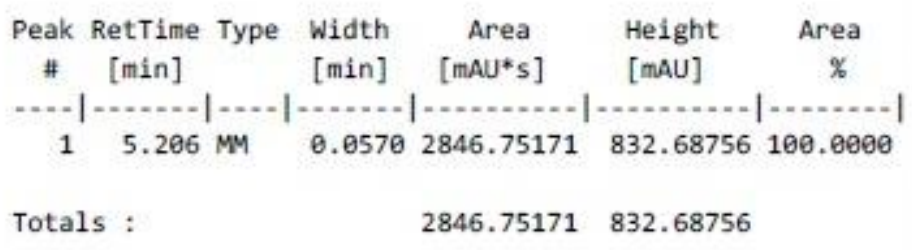
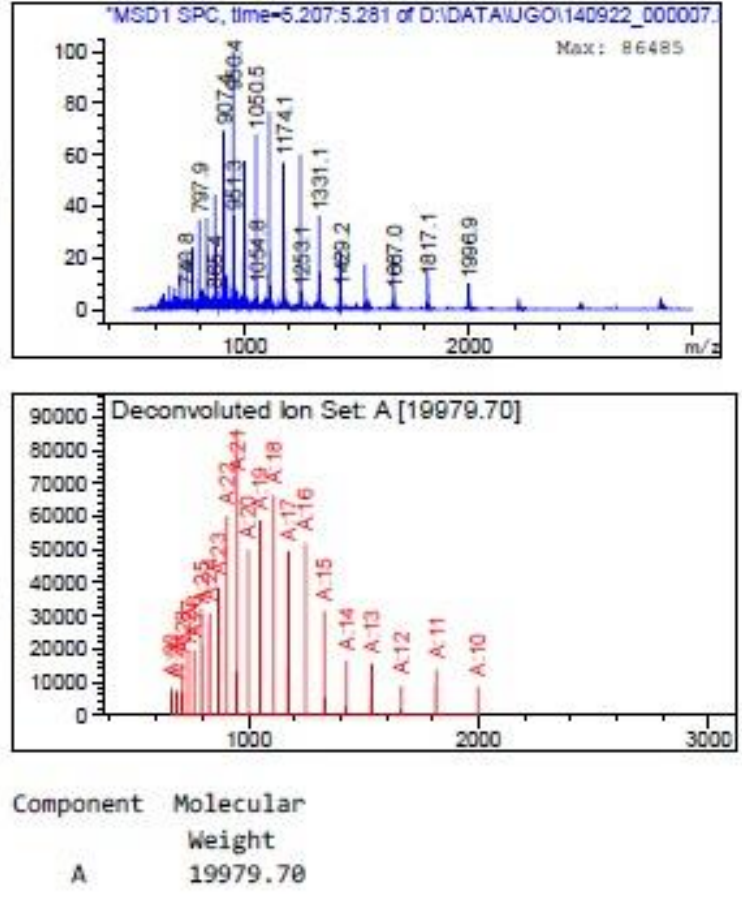
ORN6-Cy3/Cy5, pre-miR-21

UAGCUUAUCAGA $\underline{\mathbf{C} U G A U G U U G A C U G U U G A A U C U C A U G G C A A C A C C A G U \underline{C} G A U G G G C U G U C}$

Mass calculated 20538.28, found 20536.52

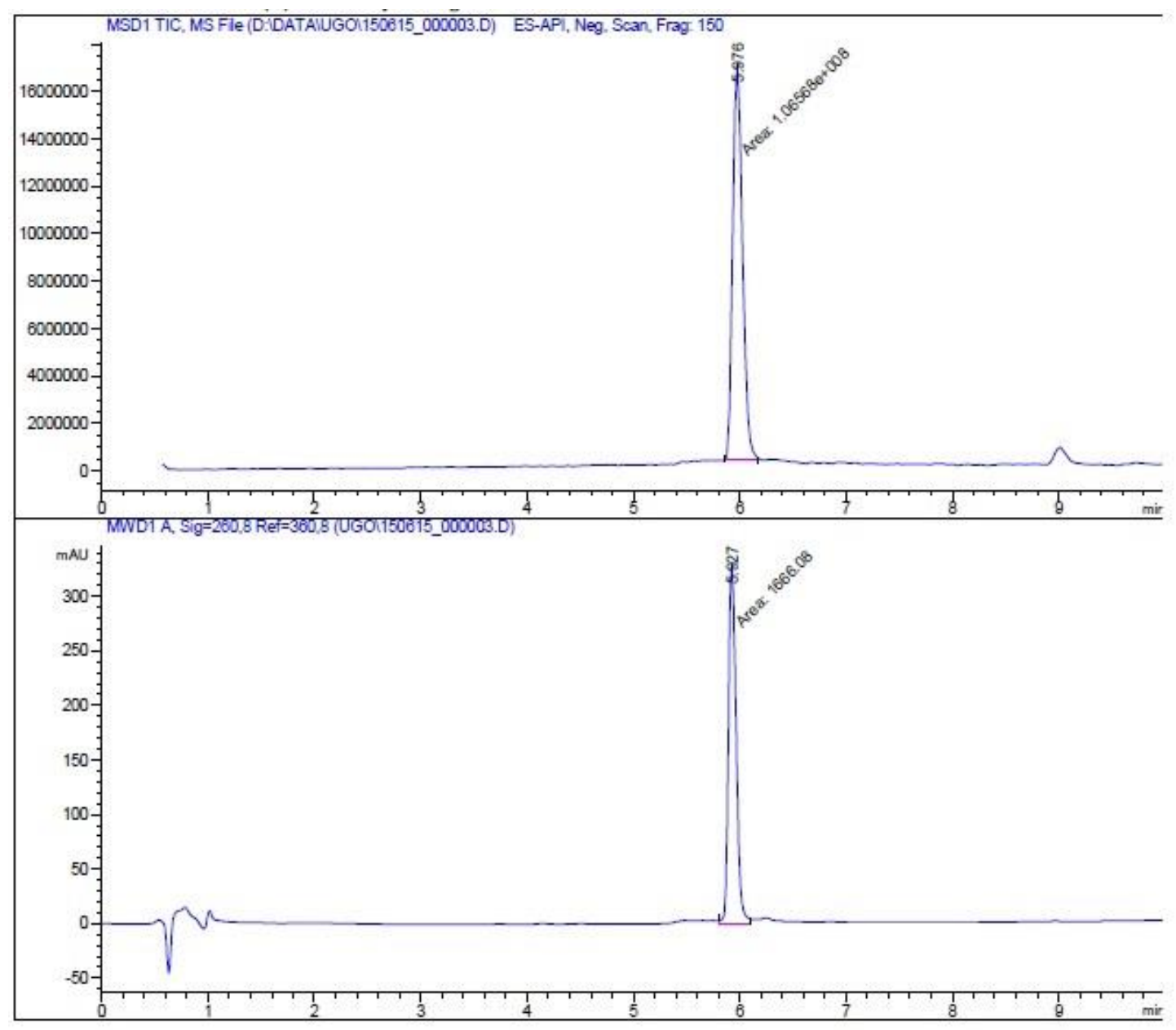

Signal 1: MSD1 TIC, MS File

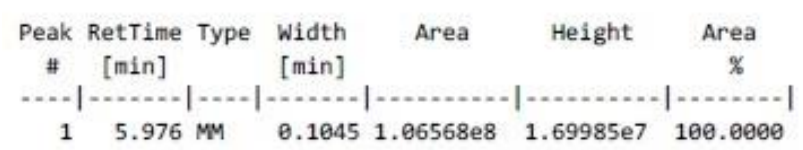

Totals:

$1.06568 \mathrm{e} 8 \quad 1.69985 \mathrm{e} 7$

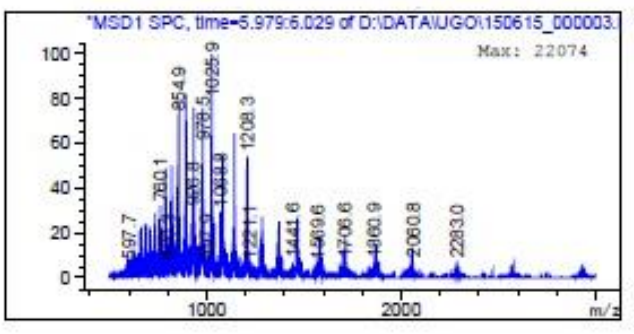

Signal 2: MWD1 A, Sig=260,8 Ref $=360,8$

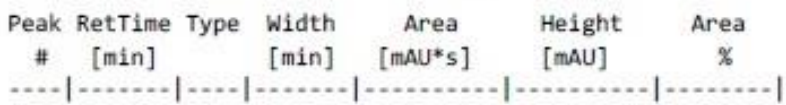

\begin{tabular}{ll|l|l|l|l|}
1 & 5.927 MM & 0.0842 & 1666.08313 & 329.68893 & 100.0000
\end{tabular}

Totals :

$1666.08313 \quad 329.68893$

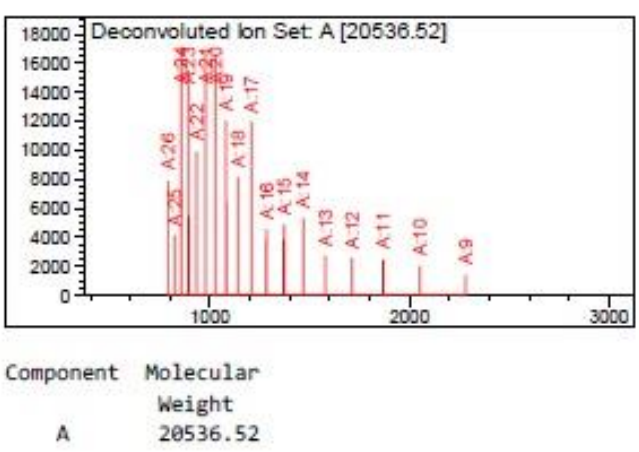




\section{ORN7-Cy3/Cy5, pre-miR-106a}

AAAAGUGC्CUUACAGUGCAGGUAGCUUUUUGAGAUCUACUGCAAUGUAAGCA $\underline{\text { CUUCUUAC }}$

Mass calculated 20186.08, found 20186.35

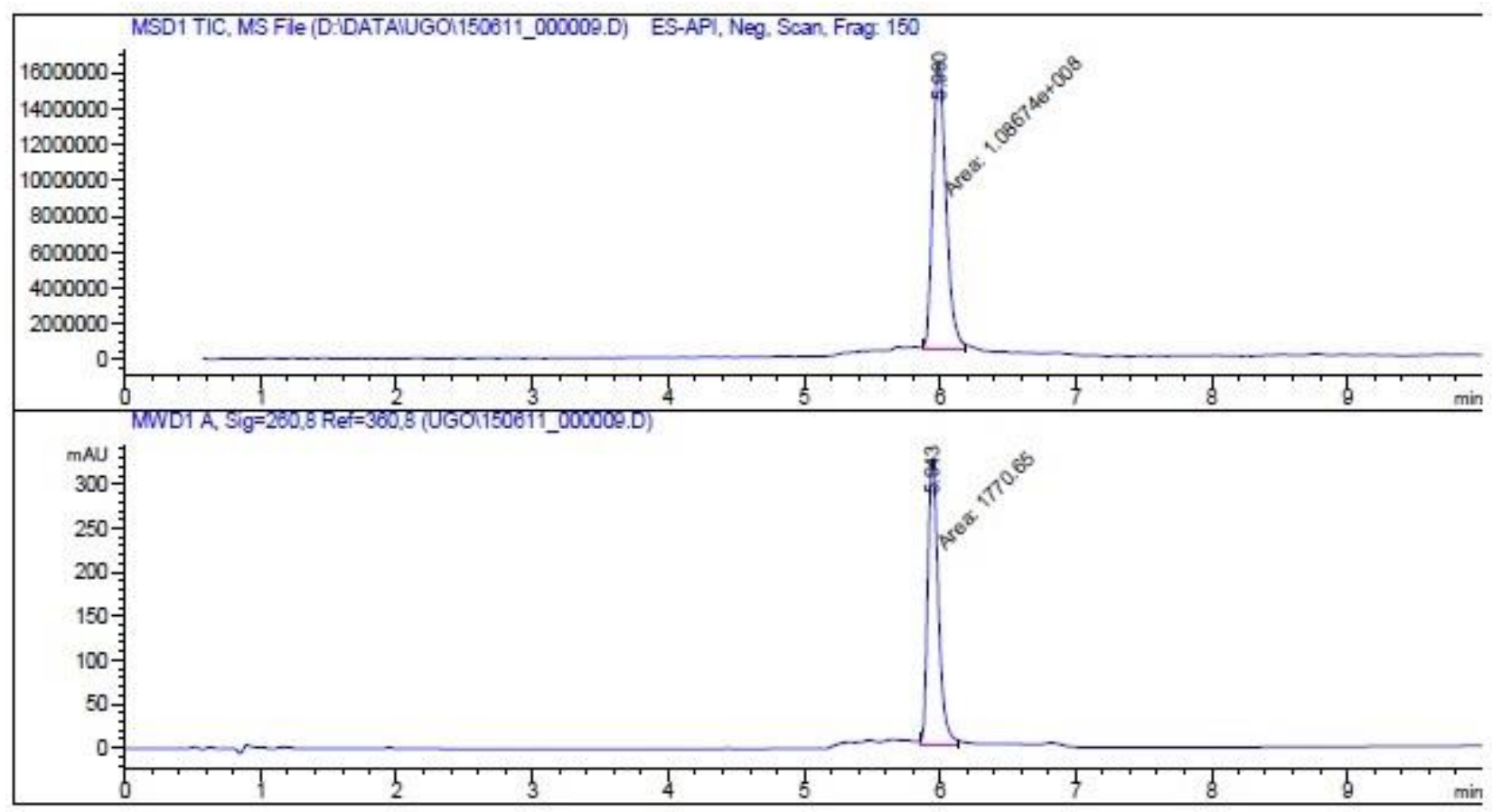

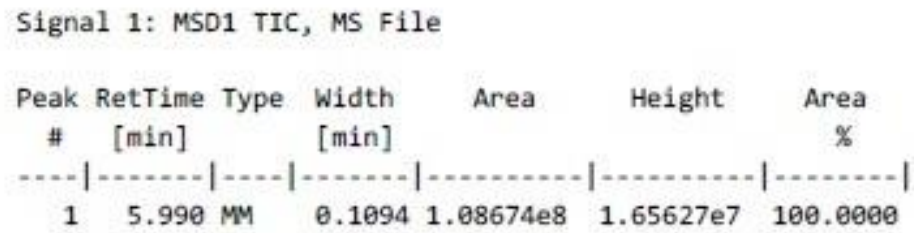

Totals :

$1.08674 \mathrm{e} 8 \quad 1.65627 \mathrm{e} 7$

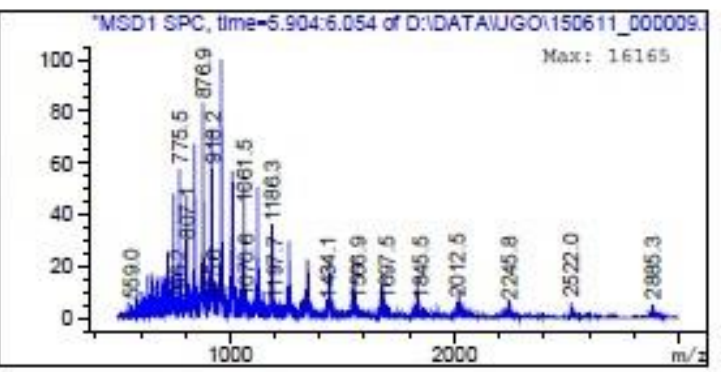

Signal 2: MWD1 A, Sig=260, 8 Ref $=360,8$

Peak RetTime Type width Area Height Area

\# [min] [min] [mAU*s] [mAU]

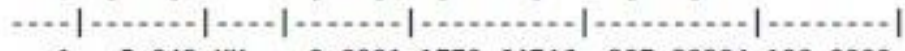

$\begin{array}{llllll}1 & 5.943 & \text { MM } \quad 0.0901 & 1770.64746 \quad 327.39304 & 100.0000\end{array}$

Totals :

$1770.64746 \quad 327.39304$

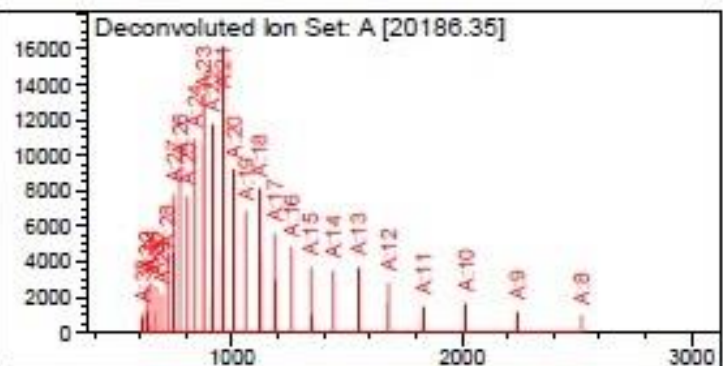

Component Molecular Weight

A 20186.35 


\section{ORN8-Cy3/Cy5, pre-miR-106a}

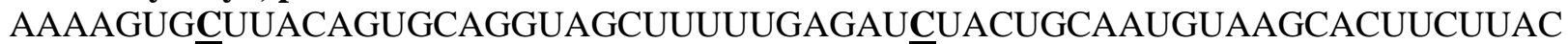

Mass calculated 20186.08, found $20208.43\left(+\mathrm{Na}^{+}\right), 20184.60$

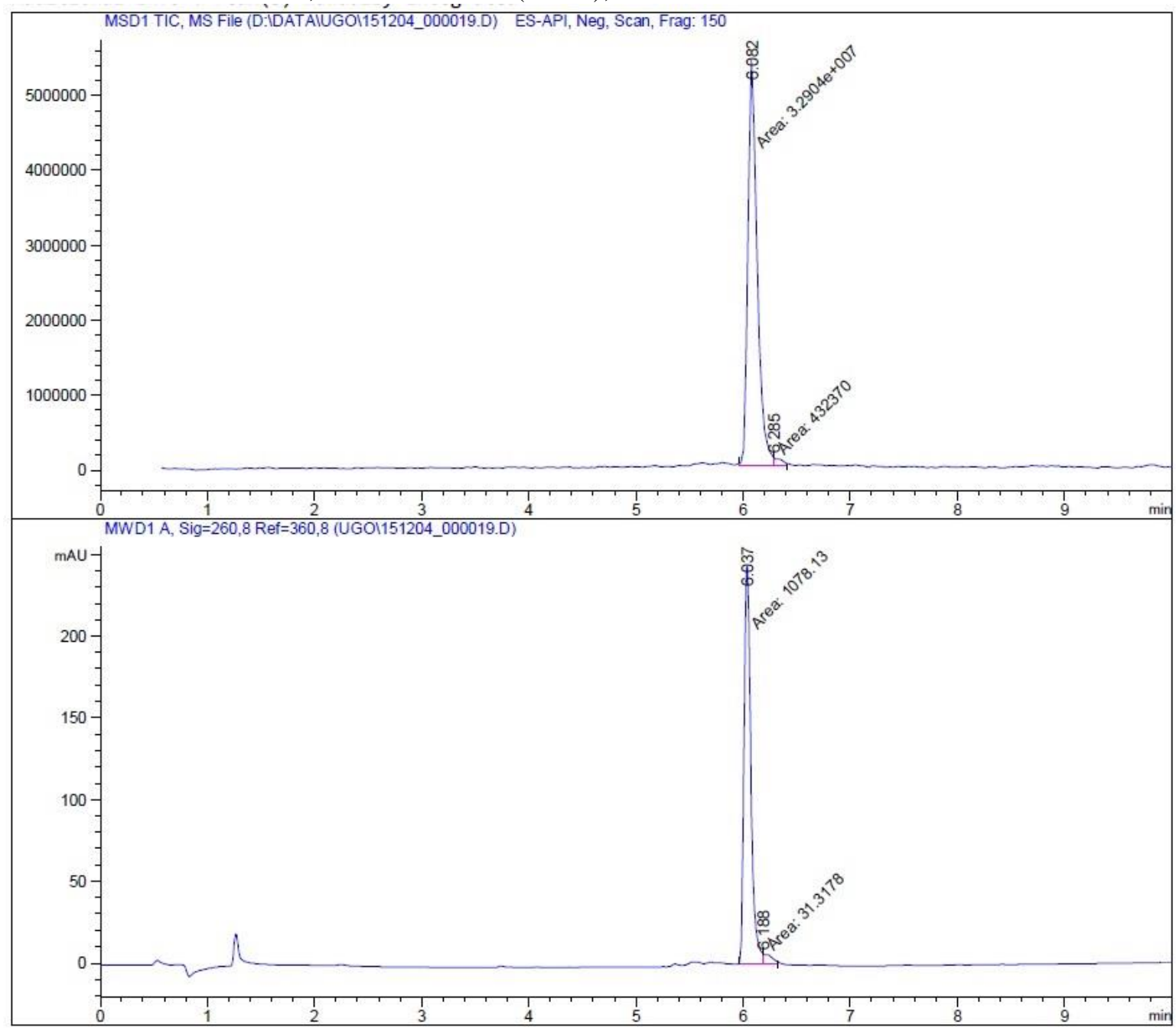

Signal 1: MSD1 TIC, MS File

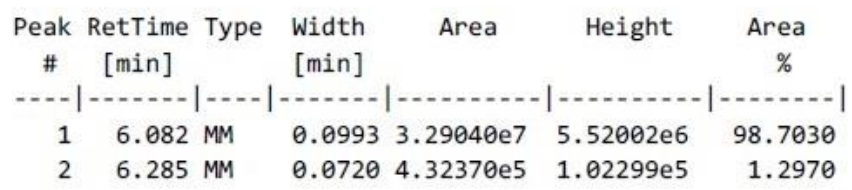

Totals :

$3.33364 \mathrm{e} 7 \quad 5.62232 \mathrm{e} 6$

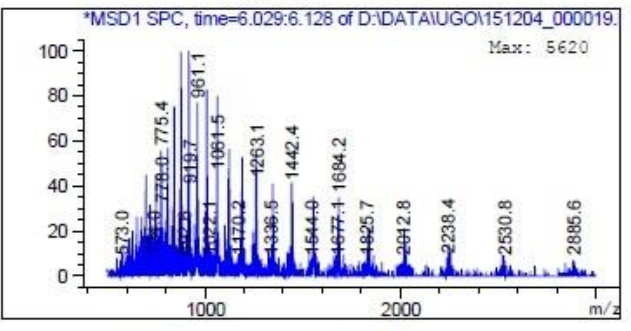

Signal 2: MWD1 A, Sig $=260,8$ Ref $=360,8$

$$
\begin{aligned}
& \text { Peak RetTime Type Width Area Height Area } \\
& \begin{array}{cccccc}
\# & {[\mathrm{~min}]} & {[\mathrm{min}]} & {[\mathrm{mAU} * \mathrm{~s}]} & {[\mathrm{mAU}]} & \% \\
\hline 1 & 6.037 \mathrm{MM} & 0.0734 & 1078.13025 & 244.89534 & 97.1772
\end{array} \\
& \begin{array}{lllllll}
2 & 6.188 & \text { MM } & 0.0678 & 31.31784 & 5.97308 & 2.8228
\end{array} \\
& \text { Totals : } \\
& 1109.44809 \quad 250.86842
\end{aligned}
$$

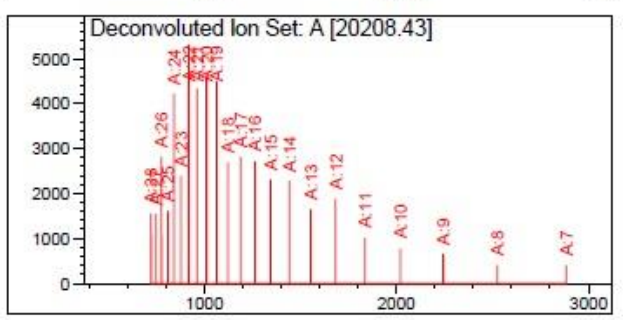

$$
\begin{array}{cl}
\text { Component } & \begin{array}{c}
\text { Molecular } \\
\text { Weight }
\end{array} \\
\text { A } & 20208.43 \\
\text { B } & 20184.60
\end{array}
$$




\section{ORN9-Cy3/Cy5, pre-miR-124}

CGUGUU $\underline{\mathbf{C}} A C A G C G G A C C U U G A U U U A A A U G U C C A U A C A A U U A A G G C A C G \underline{\mathbf{C}} G G U G A A U G C C$

Mass calculated 20238.18, found 20238.71

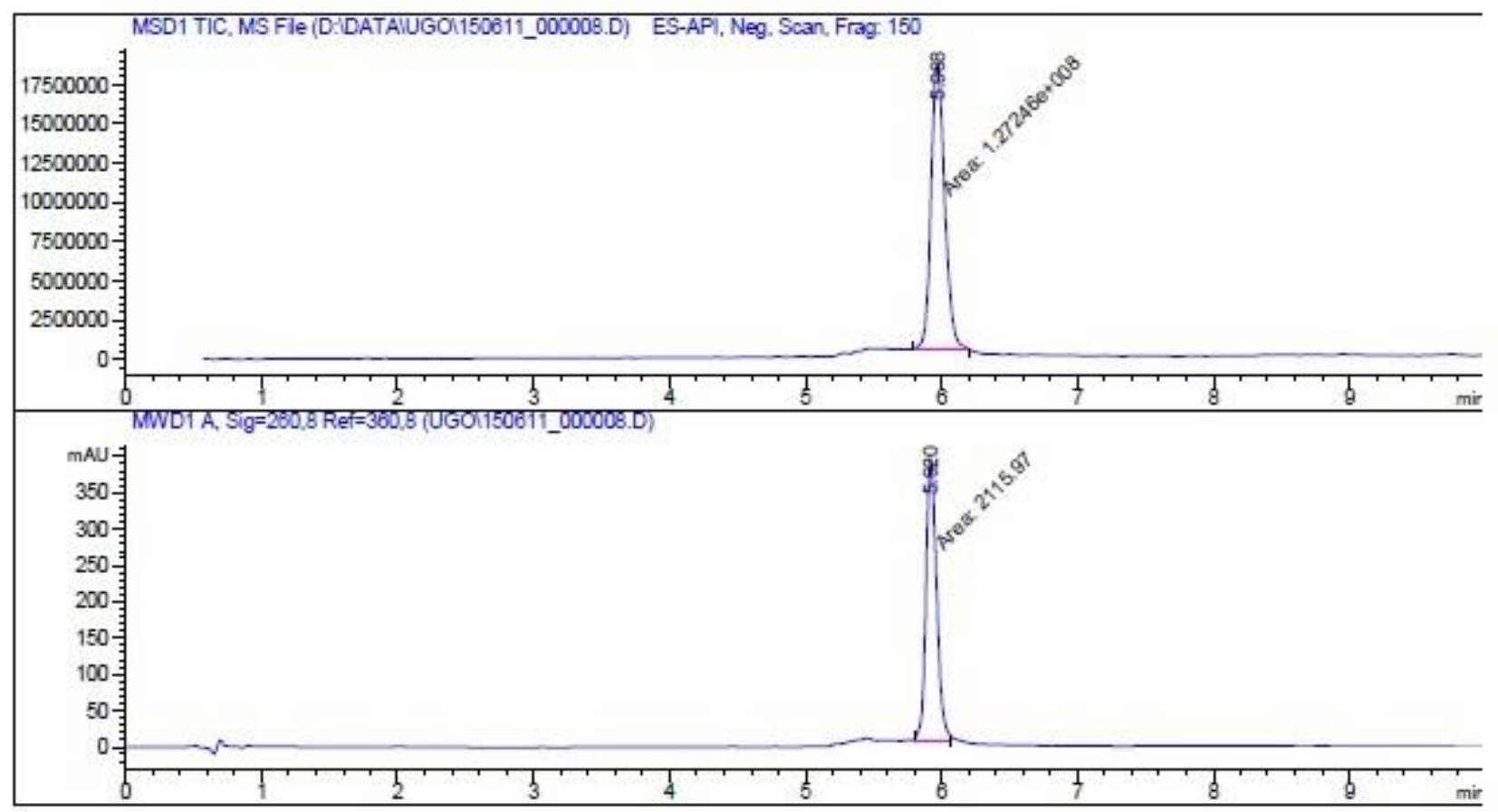

Signal 1: MSD1 TIC, MS File

\begin{tabular}{|c|c|c|c|c|c|c|}
\hline $\begin{array}{c}\text { Peak } \\
\#\end{array}$ & $\begin{array}{c}\text { RetTime } \\
\text { [min] }\end{array}$ & Type & $\begin{array}{l}\text { Width } \\
\text { [min] }\end{array}$ & Area & Height & $\begin{array}{c}\text { Area } \\
\quad \%\end{array}$ \\
\hline$\ldots$ & $\ldots . .$. & 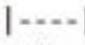 & ............ & | & | & | \\
\hline 1 & 5.968 & MM & 0.1132 & $1.27246 \mathrm{e} 8$ & $1.87402 \mathrm{e} 7$ & 100.0000 \\
\hline Tot: & & & & $1.27246 \mathrm{e} 8$ & $1.87402 \mathrm{e} 7$ & \\
\hline
\end{tabular}

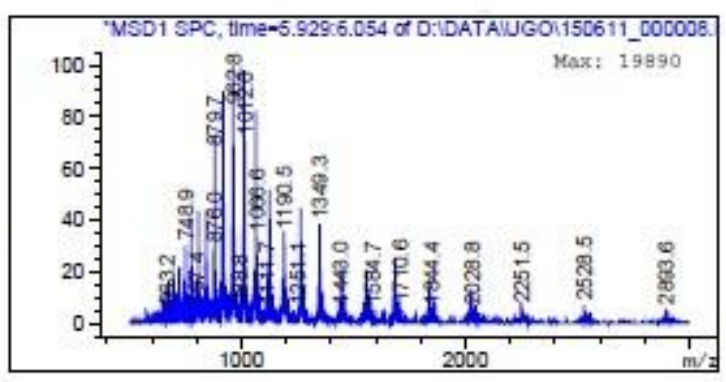

Signal 2: MWD1 A, Sig $=260,8$ Ref $=360,8$

\begin{tabular}{cccccc}
$\begin{array}{c}\text { Peak RetTime Type width } \\
\text { \# [min] }\end{array}$ [min] & $\begin{array}{c}\text { Area } \\
\text { [mAU*s] }\end{array}$ & $\begin{array}{c}\text { Height } \\
\text { [mAU] }\end{array}$ & $\begin{array}{c}\text { Area } \\
\%\end{array}$ \\
\hdashline 1 & 5.920 MM & 0.0910 & 2115.97119 & 387.58792 & 100.0000
\end{tabular}

Totals :

$2115.97119 \quad 387.58792$

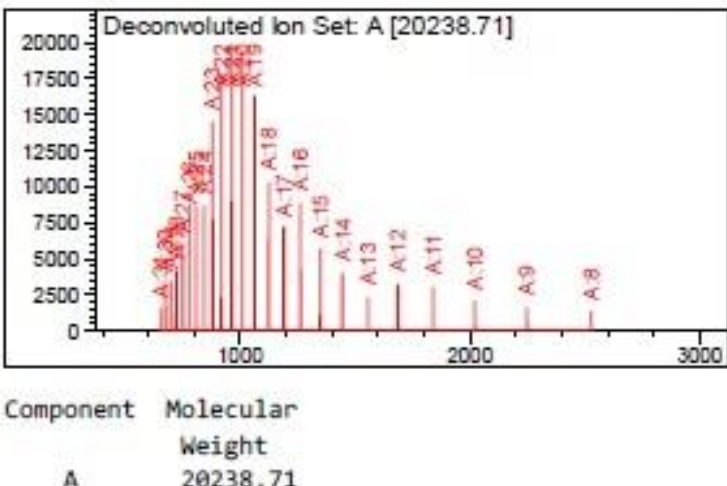


ORN10-Cy3/Cy5, pre-miR-124

CGUGUUCACAGCGGACCUUGAUUUAAAUGUCㅡAUACAAUUAAGGCACGㅡGGUGAAUGCC

Mass calculated 20238.18, found 20237.22

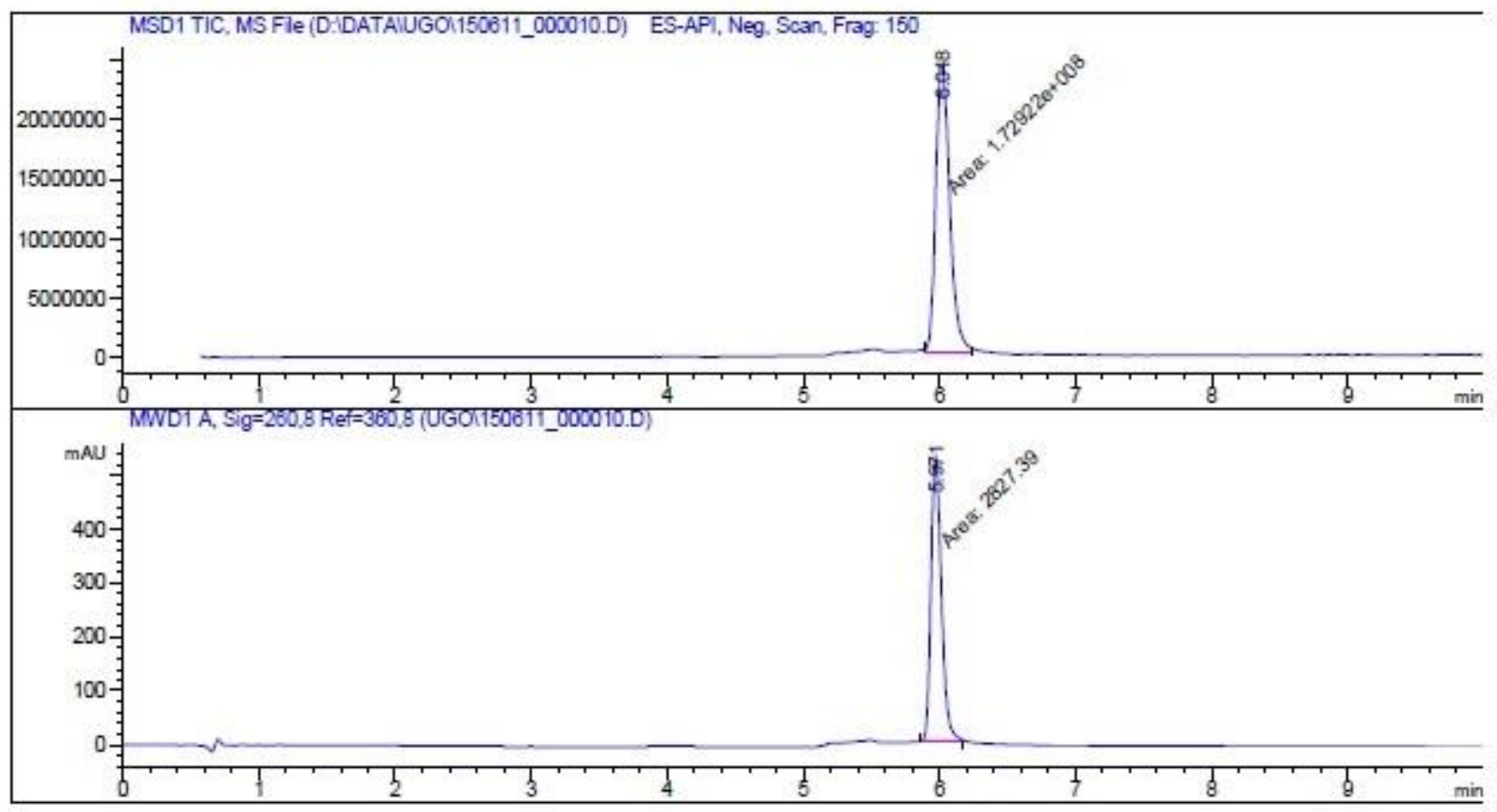

Signal 1: MSD1 TIC, MS File

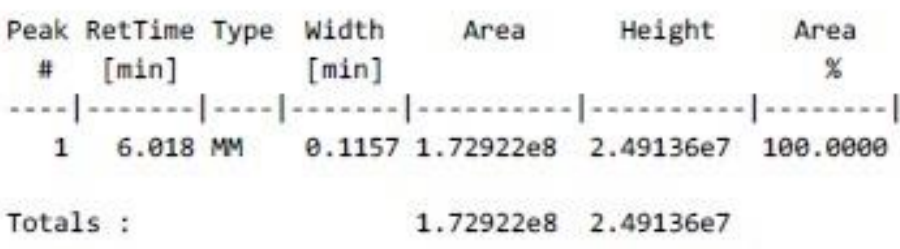

Signal 2: MWD1 A, Sig=260,8 Ref=360,8

\begin{tabular}{|c|c|c|c|c|c|}
\hline $\begin{array}{c}\text { Peak } \\
\quad \#\end{array}$ & $\begin{array}{l}\text { RetTime Type } \\
\text { [min] }\end{array}$ & $\begin{array}{l}\text { width } \\
\text { [min] }\end{array}$ & $\begin{array}{c}\text { Area } \\
\text { [mAU*s] }\end{array}$ & $\begin{array}{l}\text { Height } \\
\text { [mAU] }\end{array}$ & $\begin{array}{c}\text { Area } \\
\%\end{array}$ \\
\hline 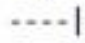 & $+\ldots+1=$ & n........ & | $\ldots \ldots . . . .$. & ............. & $|\ldots \ldots|$ \\
\hline 1 & $5.971 \mathrm{MM}$ & 0.0893 & 2827.38794 & 527.46393 & 100.0000 \\
\hline ta & : & & 2827.38794 & 527.46393 & \\
\hline
\end{tabular}
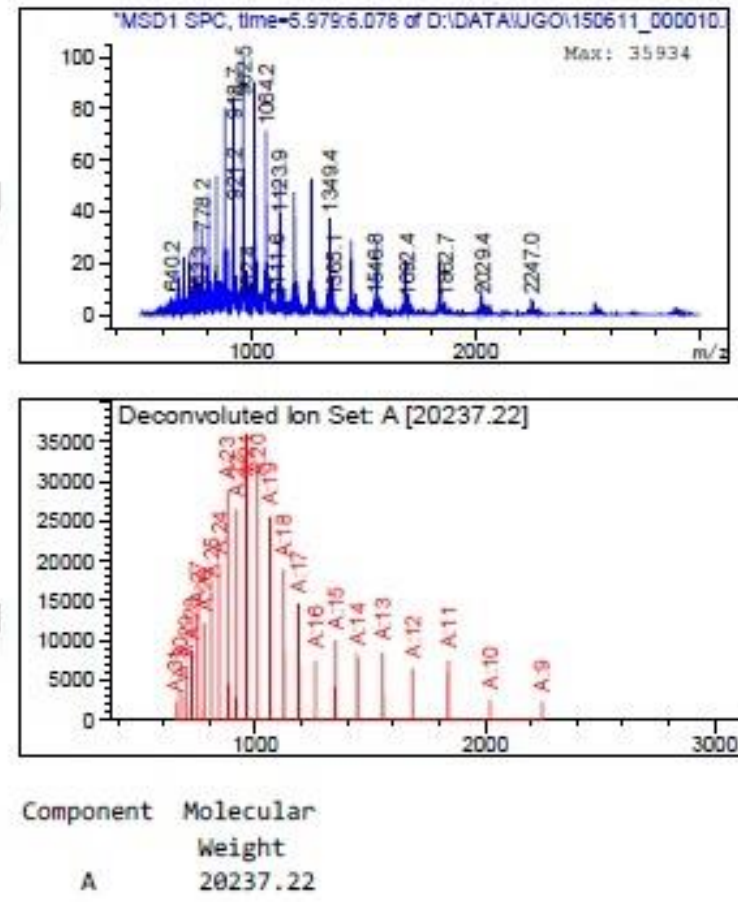

A 20237.22 


\section{ORN11-Cy3/Cy5, pre-miR-20b}

CAAAGUGCUCAUAGUGCAGGUAGUUUUGGCAUGACUCUACUGUAGUAUGGGCAC̣UUCCAG

Mass calculated 20578.38, found 20576.07

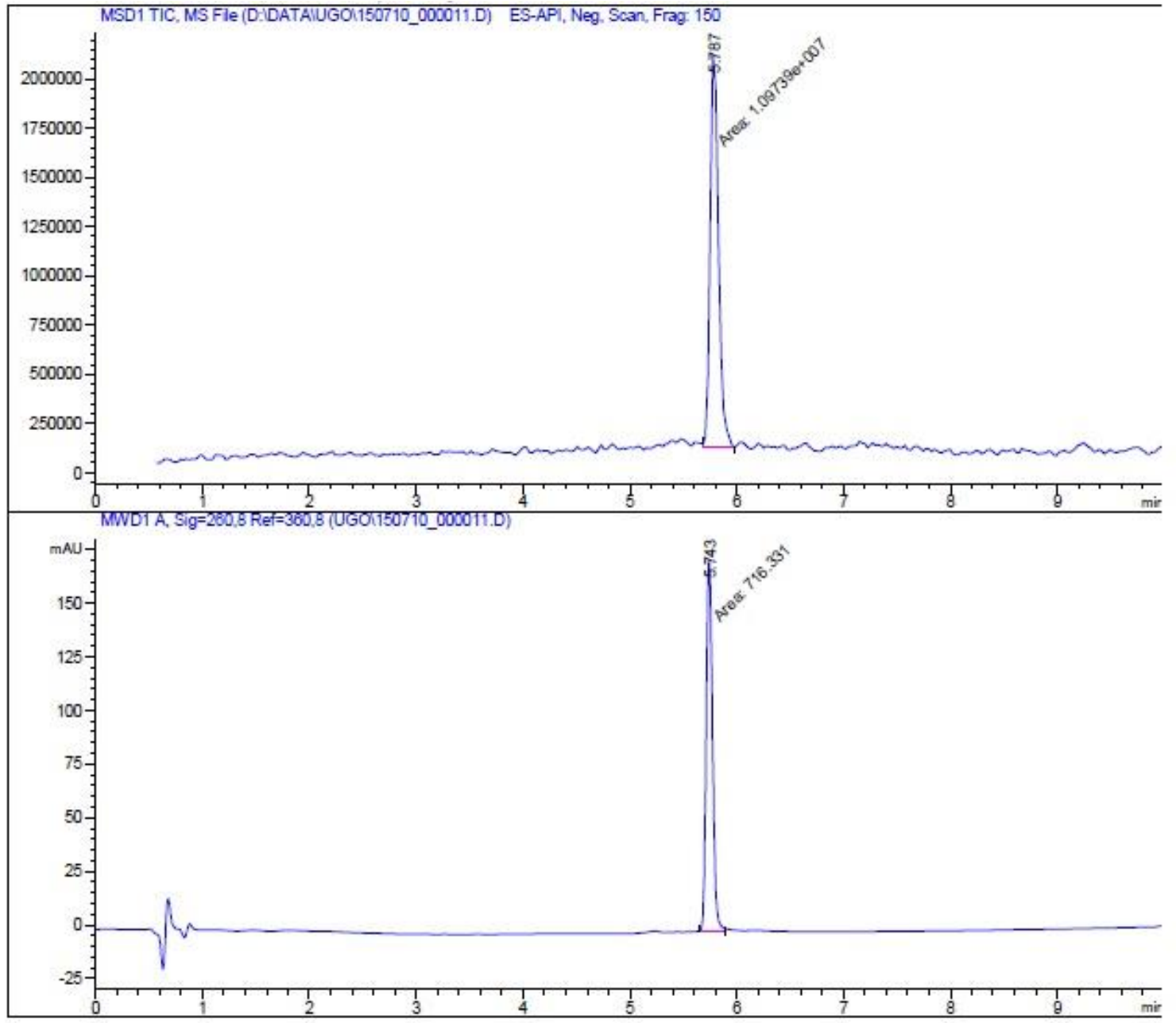

Signal 1: MSD1 TIC, MS File

Peak RetTime Type width Area Height Area

\# [min] [min]

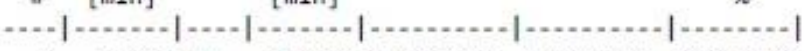

$\begin{array}{lllllll}1 & 5.787 & \mathrm{MM} & 0.0881 & 1.09739 \mathrm{e} 7 & 2.07550 \mathrm{e} & 100.0000\end{array}$

Totals :

$1.09739 \mathrm{e} 7 \quad 2.07550 \mathrm{e} 6$

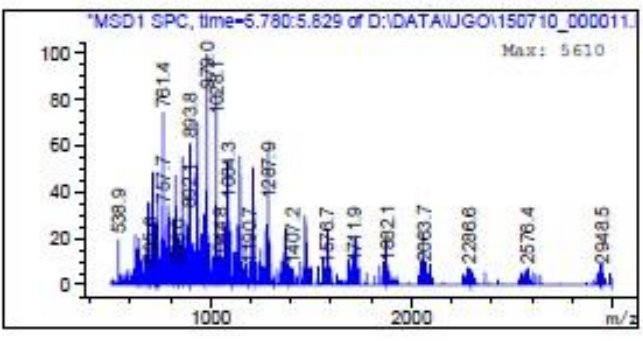

Signal 2: MWD1 A, Sig $=260,8$ Ref $=360,8$

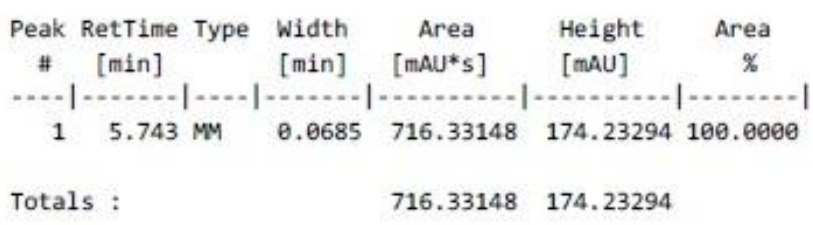

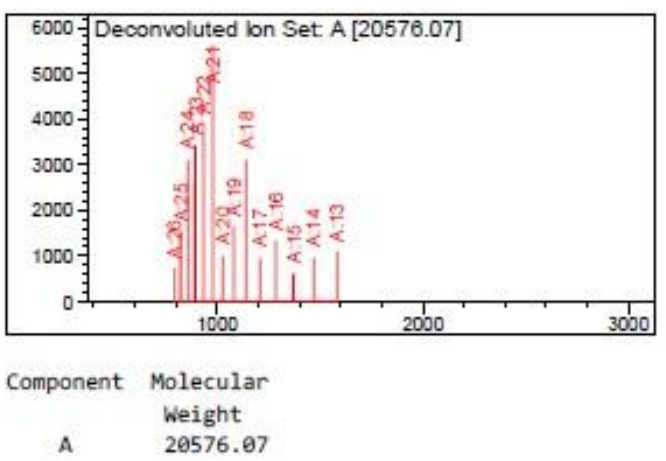




\section{ORN12-Cy3/Cy5, pre-miR-20b}

CAAAGUGCUCAUAGUGCAGGUAGUUUUGGCAUGACUCUACUGUAGUAUGGGCACUUCCAG

Mass calculated 20578.38, found 20575.76

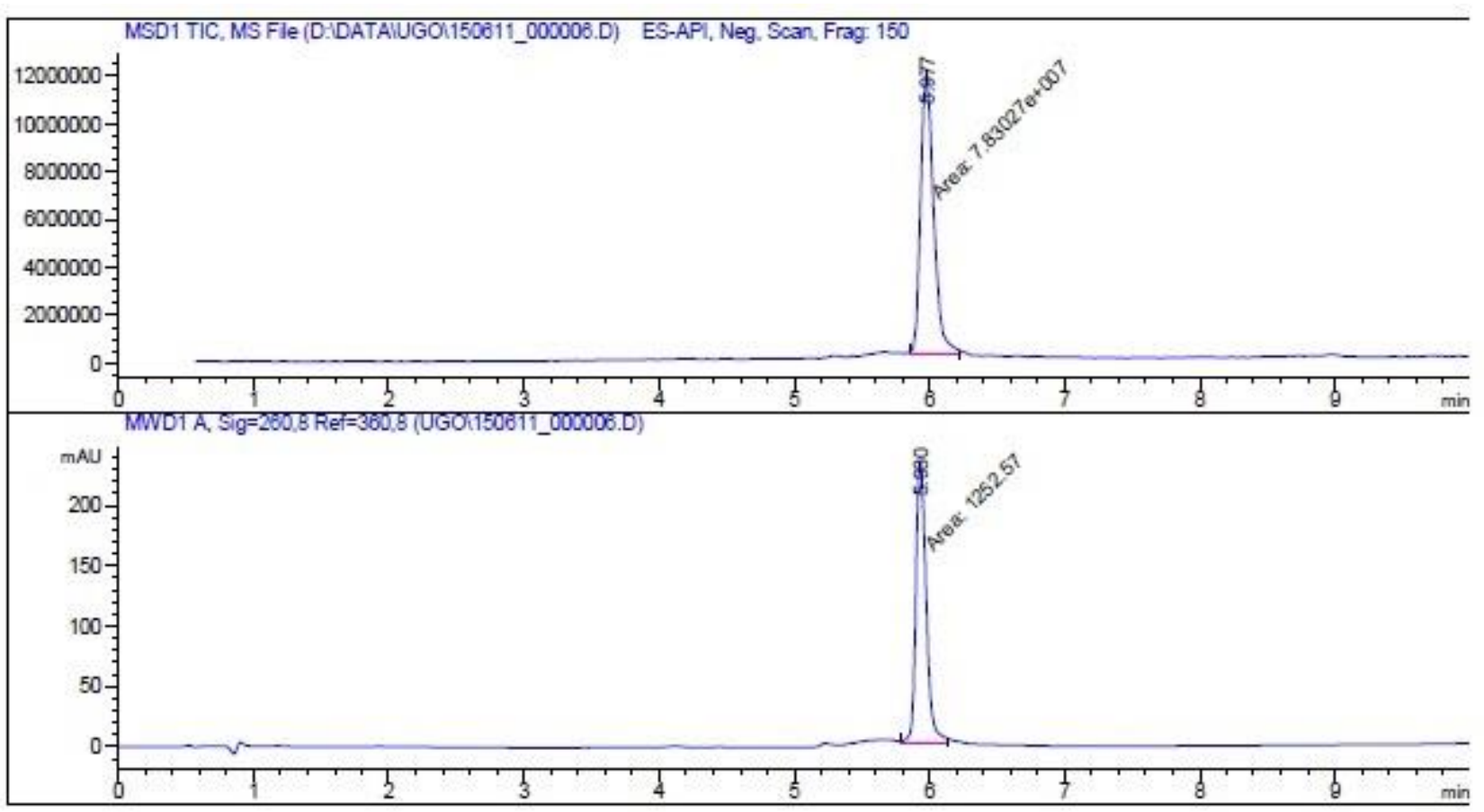

Signal 1: MSD1 TIC, MS File

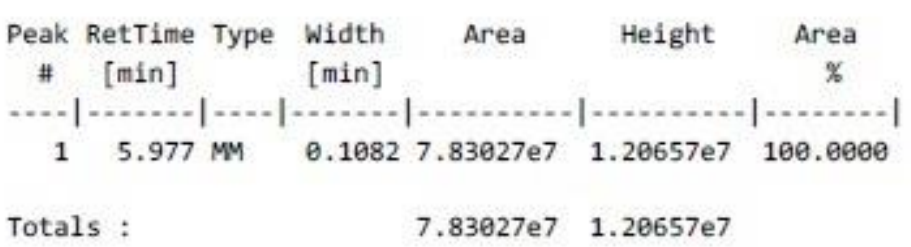

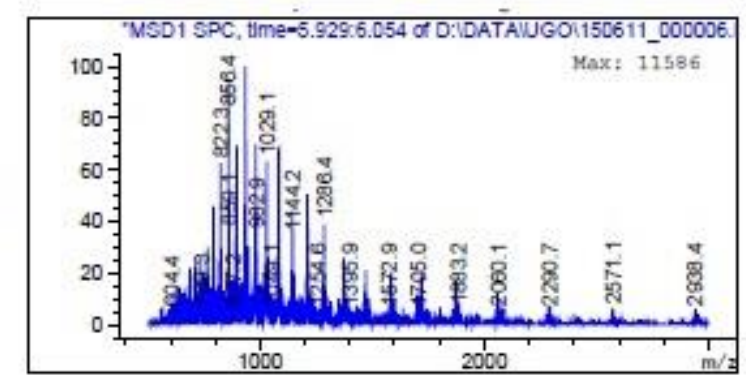

Signal 2: MWD1 A, Sig=260, 8 Ref $=360,8$

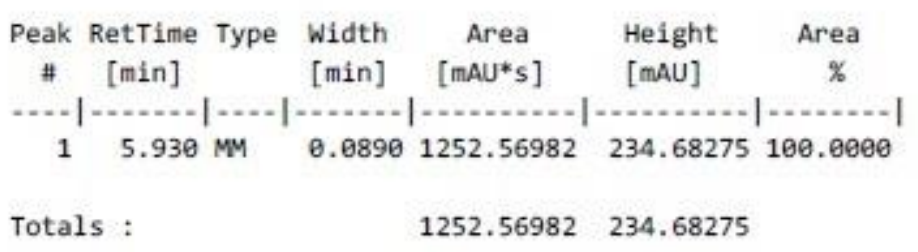

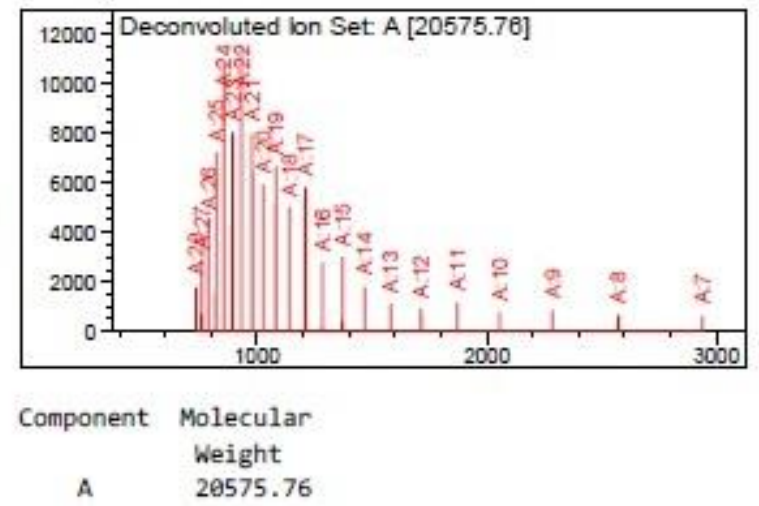


ORN13-Cy3/Cy5, pre-miR-122

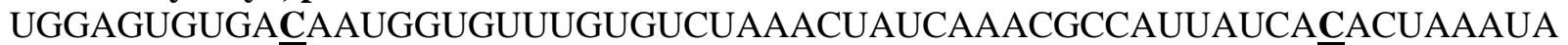

Mass calculated 19887.20, found 19887.25

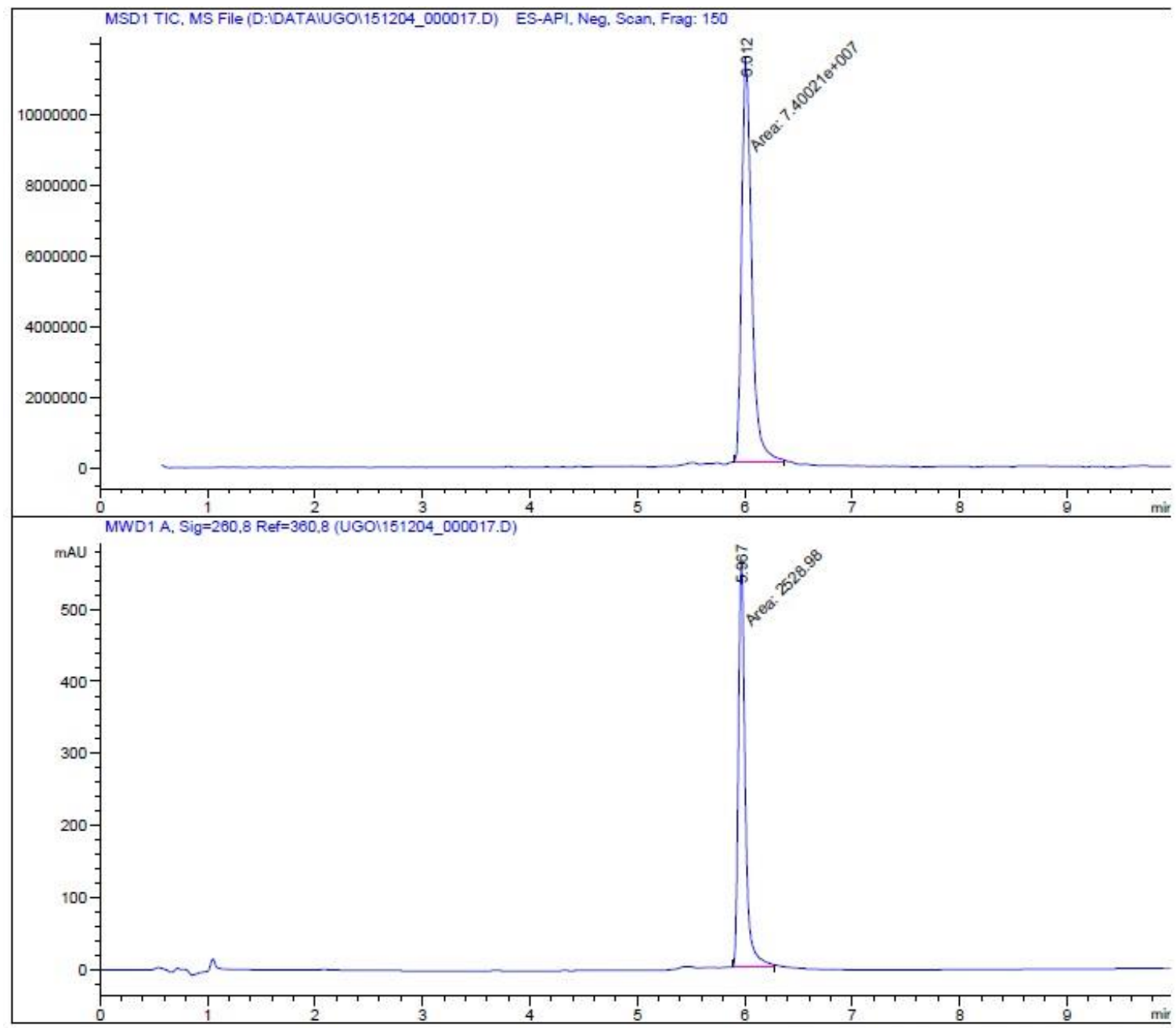

Signal 1: MSD1 TIC, MS File

$\begin{array}{cccc}\text { Peak RetTime Type Width Area Height } & \text { Area } \\ \# \quad[\text { min] } & {[\text { min] }} & \end{array}$

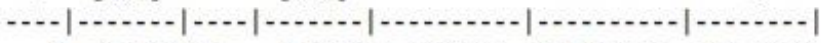

$\begin{array}{lllllll}1 & 6.012 & \text { MM } & 0.1039 & 7.40021 \mathrm{e} 7 & 1.18678 \mathrm{e} 7 & 100.0000\end{array}$

Totals :

$7.40021 \mathrm{e} 7 \quad 1.18678 \mathrm{e} 7$

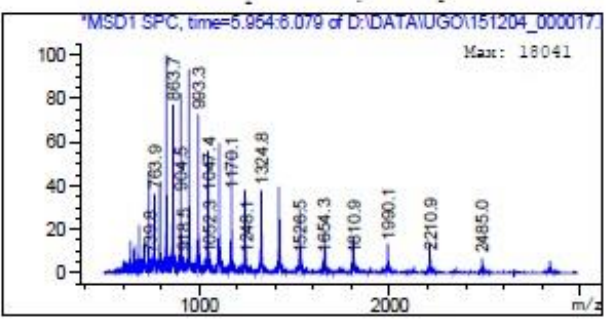

Signal 2: MWD1 A, Sig=260, 8 Ref $=360,8$

Peak RetTime Type Width Area Height Area

\# [min]

[min] [mAU*s] [mAU] \%

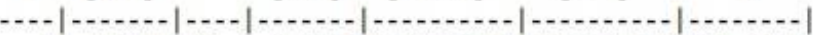

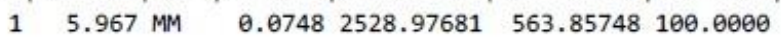

Totals :

$2528.97681 \quad 563.85748$

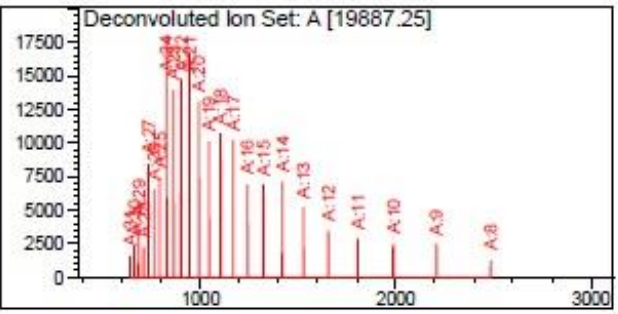

Component Molecular

Weight

A. 19887.25 
ORN14-Cy3/Cy5, pre-miR-122

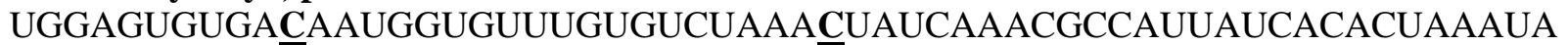

Mass calculated 19887.20, found 19886.65
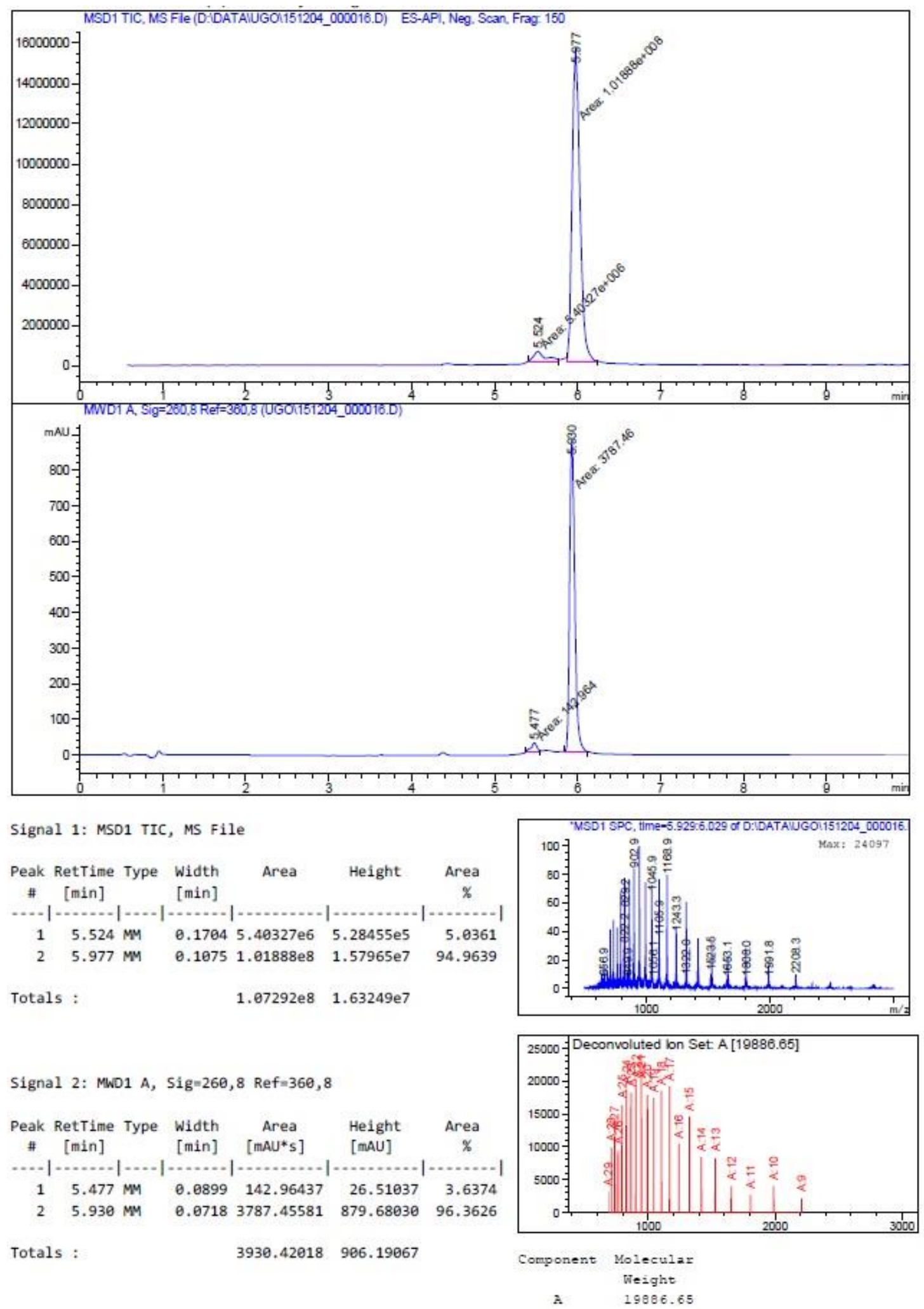


\section{RNAse digestion assay}

\section{Experimental procedure}

$1 \mu \mathrm{L}$ of a $20 \mu \mathrm{M}$ solution of RNA was diluted in $15 \mu \mathrm{L}$ of water. Fluorescence was measured every minute for 5 min on a Tecan Plate-reader Infinite M1000 at $675 \mathrm{~nm}$ (5 nm bandwidth) after excitation at $548 \mathrm{~nm}$ (Cy3 excitation, FRET) and $640 \mathrm{~nm}$ (direct Cy5 excitation). $1 \mu \mathrm{L}$ of Fermentas RNAse A enzyme was added to the solution, incubated at room temperature for 1 minute and the fluorescence was measured every minute for $5 \mathrm{~min}$ as described previously. 


\section{Dicer assays with ORN13-Cy3/Cy5 and ORN14-Cy3/Cy5}

\section{Experimental procedure}

Dicer processing experiments were conducted with a Gelantis Recombinant Turbo Dicer Enzyme Kit (Cat \# T520002) following manufacturer recommendations with minor modifications.

$1.25 \mu \mathrm{g}$ of ORN-Cy3/Cy5 was deposed into an Eppendorf and dried on a SpeedVac. Successively $3 \mu \mathrm{L}$ of RNA free water, $1 \mu \mathrm{L}$ of $10 \mathrm{mM}$ ATP solution, $1 \mu \mathrm{L}$ of $5 \mathrm{X}$ BSA, $2 \mu \mathrm{L}$ of $50 \mathrm{mM} \mathrm{MgCl}$ and $1 \mu \mathrm{L}$ of Turbo Dicer Reaction Buffer were added. After mixing, $1.6 \mu \mathrm{L}$ of the solution was removed from the solution and stored separately as starting material reference for fluorescence measurements (sample 1). The remaining solution was added $2 \mu \mathrm{L}$ of Turbo Dicer Enzyme (1 unit) and incubated for $2 \mathrm{~h}$ at $37{ }^{\circ} \mathrm{C}$ under gentle shaking. The enzymatic reaction was stopped by the addition of $2 \mu \mathrm{L}$ of a Turbo Dicer Stop Solution. $2 \mu \mathrm{L}$ of the solution was removed from the solution and stored separately for fluorescence measurements (sample 2).

The remaining solution was analyzed by LC-MS with a gradient of 5 to $55 \%$ buffer B in buffer A over 10 min then $55 \%$ to $100 \%$ over $2.5 \mathrm{~min}$ (buffer A: 0.4M HFIP, $15 \mathrm{mM}$ triethylamine; buffer B: $\mathrm{MeOH}$ ).

Samples 1 and 2 were dissolved in water to reach a final volume of $15 \mu \mathrm{L}$ and analyzed on a Tecan Plate-reader Infinite M1000 at $675 \mathrm{~nm}$ (5 nm bandwidth) after excitation at $548 \mathrm{~nm}$ (Cy3 excitation, FRET) and $640 \mathrm{~nm}$ (direct Cy5 excitation). To sample 2 was added $1 \mu \mathrm{L}$ of a $200 \mu \mathrm{M}$ solution of a 2'-MeO antisense oligonucleotide (fully complementary $5 p$ antisense, sequence: 5'-UAUUUAGUGUGAUAAUGGCGUU-3', end concentration $12.5 \mu \mathrm{M}$ ). The solution was incubated for $15 \mathrm{~min}$ and fluorescence measurements were acquired as described previously. $4 \mu \mathrm{L}$ of the antisense oligonucleotide solution were added to the solution (end concentration $50 \mu \mathrm{M}$ ) and fluorescence was measured once more as described previously. Fluorescence was normalized by dividing the fluorescence signal at 675 $\mathrm{nm}$ after excitation at $548 \mathrm{~nm}$ by the fluorescence signal at $675 \mathrm{~nm}$ after excitation at $640 \mathrm{~nm}$. 


\section{LCMS traces}

ORN13-Cy3/Cy5 $\quad{ }^{\mathrm{P}}=$ phosphate group

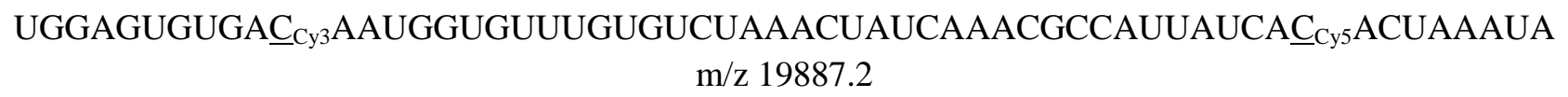

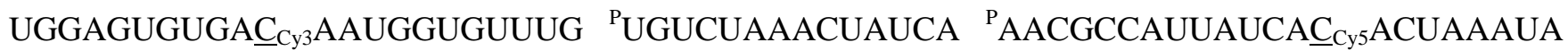
$\mathrm{m} / \mathrm{z} 7715.3$

$\mathrm{m} / \mathrm{z} 4375.7$

$\mathrm{m} / \mathrm{z} 7752.3$

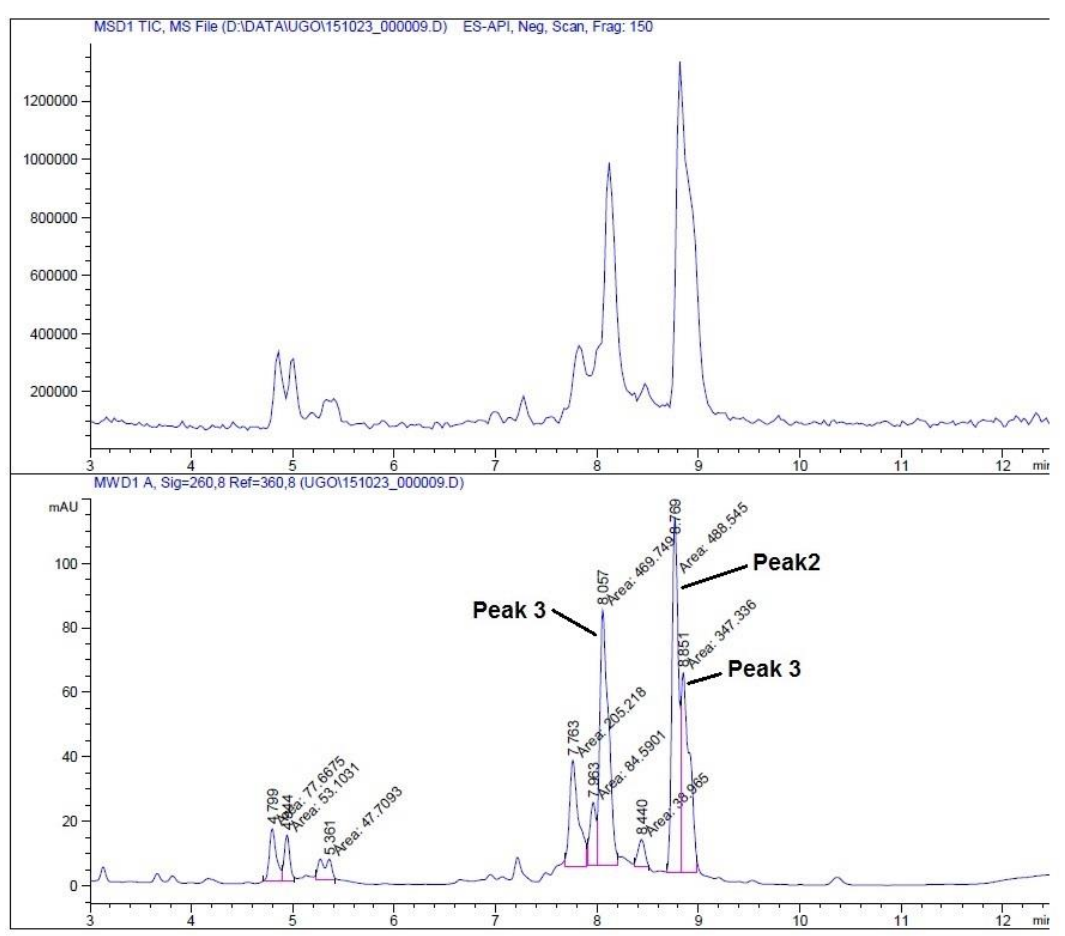

Signal 1: MSD1 TIC, MS File

Signal 2: MWD1 A, Sig $=260,8$ Ref $=360,8$

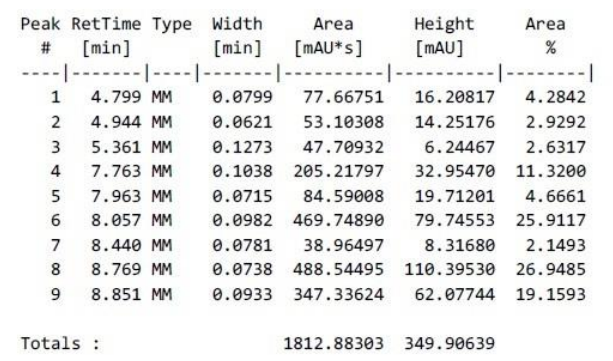

Totals :

$1812.88303 \quad 349.90639$

Peak 1
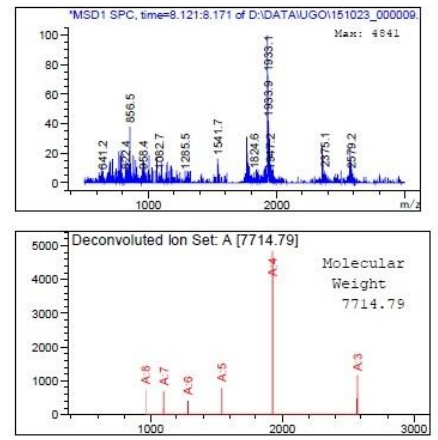

Peak2
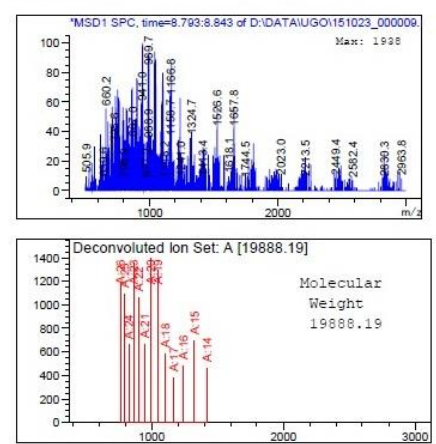

Peak 3
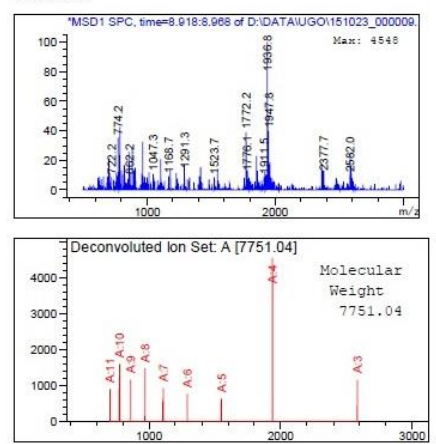


\section{ORN14-Cy3/Cy5}

UGGAGUGUGAC $\underline{C}_{\mathrm{Cy} 3}$ AAUGGUGUUUGUGUCUAAA $\underline{C}_{\mathrm{Cy} 5}$ UAUCAAACGCCAUUAUCACACUAAAUA $\mathrm{m} / \mathrm{z} 19887$

$\begin{array}{ccc}\text { UGGAGUGUGAC } \underline{C y}_{\mathbf{3}} \text { AAUGGUGUUUG } & { }^{\mathrm{P}} \text { UGUCUAAA } \underline{C}_{\mathrm{Cy} 5} \mathrm{UAUCA} & { }^{\mathrm{P}} \text { AACGCCAUUAUCACACUAAAUA } \\ \mathrm{m} / \mathrm{z} 7715.3 & \mathrm{~m} / \mathrm{z} 5190.7 & \mathrm{~m} / \mathrm{z} 7017.3\end{array}$

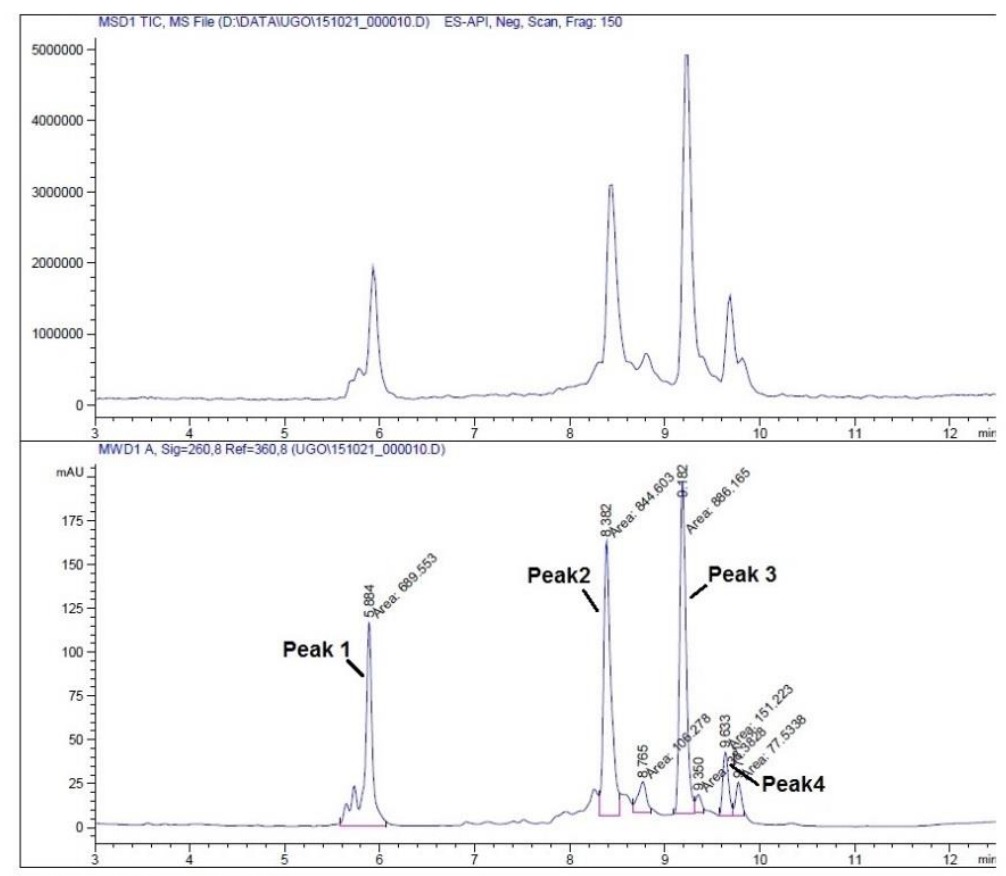

Signal 1: MSD1 TIC, MS File

Signal 2: MWD1 A, Sig $=260,8$ Ref $=360,8$

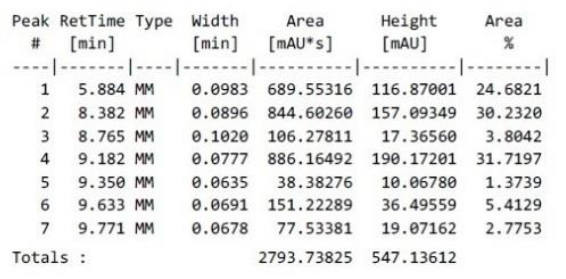

Peak 1
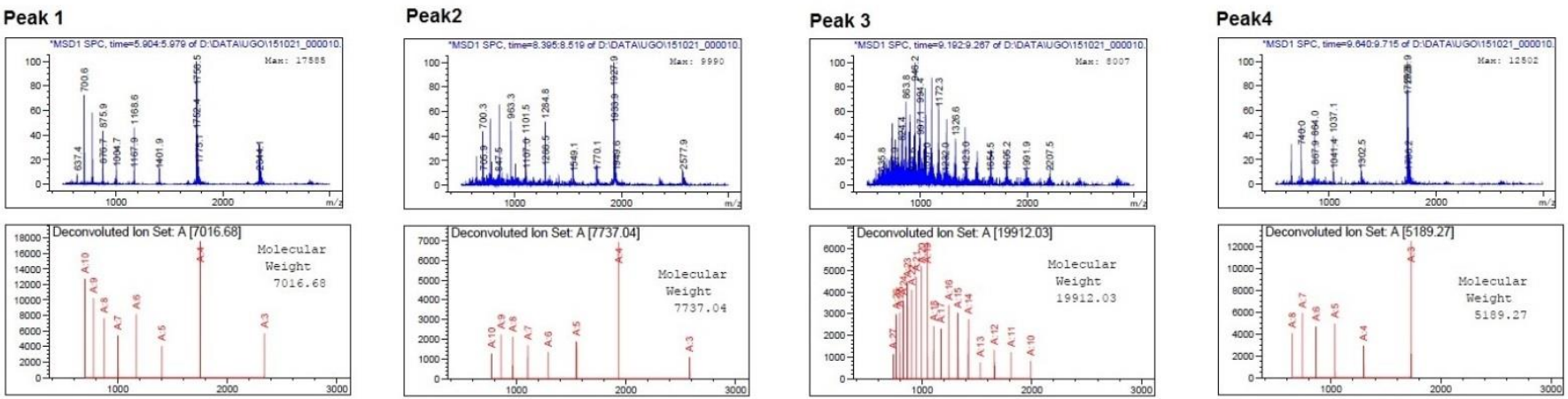
Fluorescence measurments
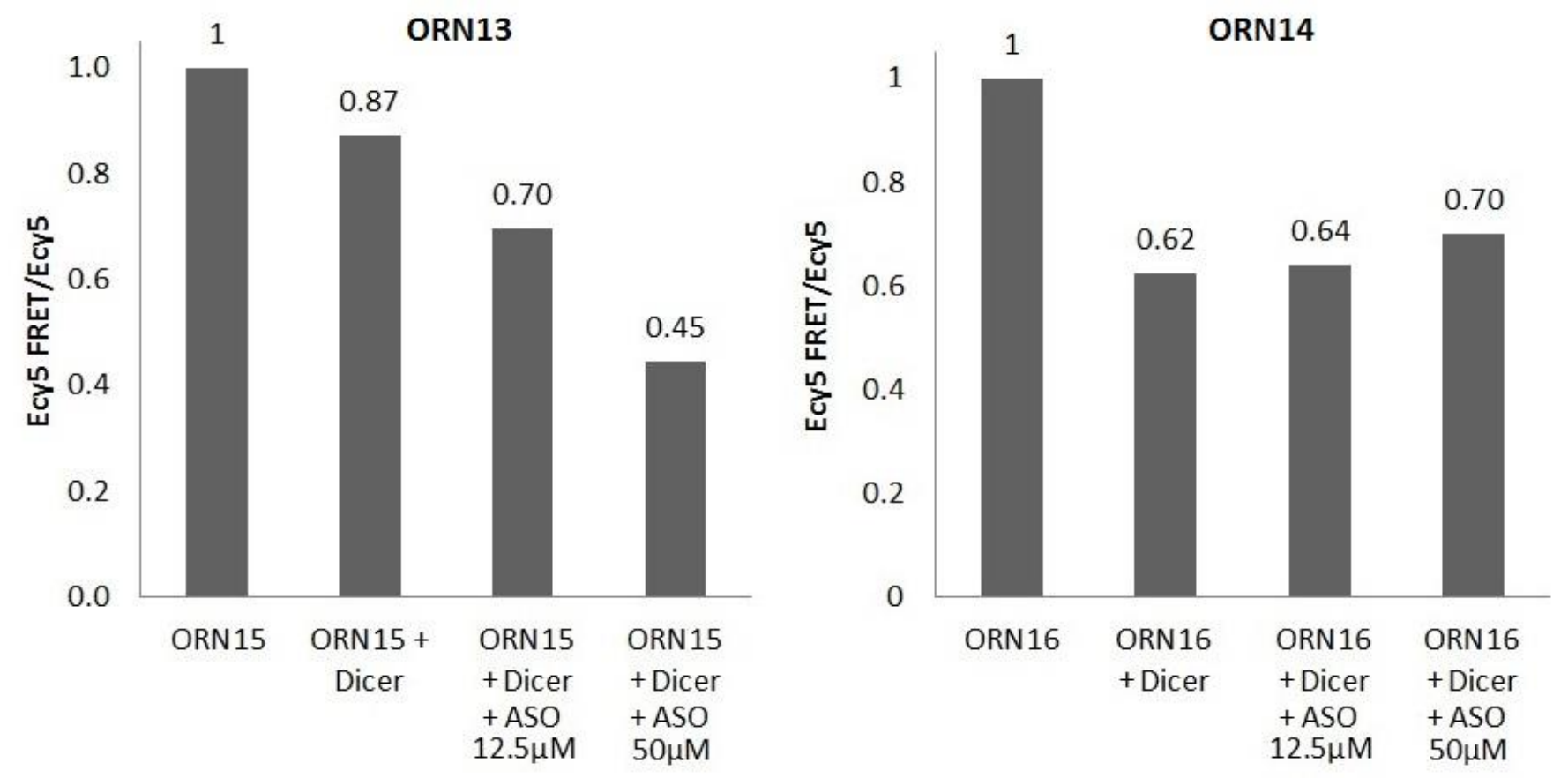